\title{
ZE STUDIÓW NAD ELITARNĄ KULTURA LUDNOŚCI GRODÓW TZW. CENTRALNYCH PAŃSTWA PIERWSZYCH PIASTÓW, CZYLI PONOWNIE O WCZESNOŚREDNIOWIECZNYM GRZEBIENIU ZE STROSZEK POD GIECZEM. UJĘCIE PORÓWNAWCZE**
}

\author{
STUDIES ON THE ELITE CULTURE OF THE POPULATION \\ OF THE SO-CALLED CENTRAL STRONGHOLDS AT THE BEGINNING \\ OF THE PIAST DYNASTY: ANOTHER LOOK AT AN EARLY-MEDIEVAL \\ COMB FROM STROSZKI NEAR GIECZ. A COMPARATIVE APPROACH
}

\begin{abstract}
The article presents results of a repeated analysis of an ornamental comb made from an antler, discovered in an early-medieval open settlement in Stroszki (site 1, Nekla county, Wielkopolska province) from the late $9^{\text {th }}$ century or the beginning of the second half of the $10^{\text {th }}$ century. The settlement was a part of the backup facilities of the stronghold in Giecz, one of several the so-called central settlements in the Piasts' oldest state. The comb stands out for its ornaments in the form of a large fish in a net immersed in water, made by engraving the side lining which serves as the comb's grip. It has been established that it is an exclusive piece of work of Scandinavian craftsmanship, a single specimen or one from a short series that comes from the $9^{\text {th }} / 10^{\text {th }}$ centuries or the first half of the $10^{\text {th }}$ century. It represents type IB-VIII-1a according to E. Cnotliwy (1973), identical with type B1:2 according to K. Ambrosiani (1981). The ornaments bear a close resemblance to the ornaments on what is considered Frisian combs from the $9^{\text {th }}$ century or, possibly, the early $10^{\text {th }} \mathrm{c}$. An iconographic analysis of the comb has led to a hypothesis that the hygienic activities that it was used for (combing dirt and insects from hair) had a concealed symbolic sense. In this case, the comb together with similar specimens ornamented by slanting checks or filled diamonds reminiscent of a fishnet, performed the function of an anti-demon instrument. The analysed comb has been attributed to the culture of the oldest state of the Piasts where it ended up most probably as a part of ceremonial exchange between the local elites and the elites of the Baltic communities, including Scandinavian ones. It is regarded that the object's diffusion was facilitated by mental concurrence, combining the then peoples of "barbarian" Europe.
\end{abstract}

Keywords: Stroszki, Giecz, Wielkopolska, Scandinavia, Frisia, the first Piast's dominion, Viking period, combs made from antlers, fish in net motif, water, combing hair, Scandinavian mythology, magic, pagan and Christian religions, strongholds, emporia, mentality, elite culture.

* ORCID: 0000-0003-4541-5480; Instytut Archeologii i Etnologii PAN - Ośrodek Studiów Pradziejowych i Średniowiecznych, ul. Rubież 46, 61-612 Poznań, e-mail: michal.kara@iaepan.poznan.pl.

${ }^{* *} \mathrm{~W}$ artykule wykorzystane zostały dane, które uzyskano w związku z realizacją projektu badawczego $\mathrm{nr} 11 \mathrm{H} 13021682$ pt. Uściślenie $i$ weryfikacja chronologii oraz periodyzacji grodów tzw. centralnych monarchii pierwszych Piastów (Gniezno, Poznań, Giecz) na podstawie akceleratorowych datowań radiowęglowych. 
Możliwości poznawcze archeologii, jako nauki kumulatywnej, zależą m.in. od zasobów dobrze udokumentowanych źródeł kopalnych, które kolejne pokolenia badaczy poddają weryfikacji tudzież wzbogacają nowymi znaleziskami. Jest to proces permanentny, w którym te same możliwości poznawcze przypisuje się źródłom nowo odkrytym, jak też tzw. archiwalnym, z tą różnicą, iż te ostatnie, zależnie od trafności dotychczasowych ustaleń, poddaje się kompletnej lub częściowej reinterpretacji w zgodzie z aktualnym stanem wiedzy (na ten temat Abramowicz 1962; Kurnatowska i Kurnatowski 2012). Istotną rolę we wspomnianym procesie odgrywają tzw. przedsądy, zależne od podzielanego przez badaczy paradygmatu naukowego, które współczesna nauka, w tym humanistyka, kierując się ustaleniami m.in. H.G. Gadamera (1993), postrzega jako podstawy hermeneutyki filozoficznej, mającej z kolei istotne znaczenie dla poprawnego przebiegu każdej analizy naukowej. Odnotujmy zatem, że wspomniane przedsądy, nie zawsze uświadomione przez badaczy, wykluczają podjęcie analizy z pozycji neutralnej (obiektywnej) w stosunku do źródeł. Wynikają bowiem z kultury, języka, tradycji oraz stanu wiedzy badacza, które $\mathrm{w}$ procesie naukowych dociekań niewątpliwie przyczyniają się do ograniczeń natury poznawczej, mimo iż $\mathrm{w}$ kolejnych etapach analizy udział wspomnianych czynników jest naukowo rewidowany. Nie są to jednak ograniczenia decydujące o wiarygodności wniosków.

W opisanym modelu postępowania naukowego istotną rolę odgrywa zatem „krytyczny" stosunek badacza do ustaleń poprzedników jako warunek poprawności realizowanych przezeń studiów, bez czego ,[...] żaden sens nie może być ani aktualizowany, ani zachowany. Tradycja, w tym i naukowa, staje się w ten sposób miejscem przekładu metafor badanych na metafory poznawcze. Takie stanowisko [przyjęte przez nas w niniejszym artykule - dop. M.K.] motywuje w ogólnym sensie potrzebę 'wyłuskania' hipotez przedmiotowych, umożliwiających skonstruowanie nowego projektu badań starego problemu” (Kwapiński 1998, s. 79). W tym przypadku postęp naukowy oferuje badaczowi wzbogacenie konwencjonalnego pola obserwacji o przedmiotowe ustalenia innych nauk lub dyscyplin naukowych. W odniesieniu do archeologii dotyczy to zwłaszcza historiografii, historii sztuki, historii prawa, etnografii, etnologii, antropologii kulturowej i historyczno-kulturowej, religioznawstwa, lingwistyki historyczno-porównawczej, geografii, geologii, fizyki, chemii, biologii czy medycyny (zob. Tabaczyński i in. [red.] 2012). Dodajmy, iż w obecnym modelu zintegrowanych badan multidyscyplinarnych archeologia, m.in. w ramach studiów tzw. przypadków, nie tylko poszerza swe ustalenia, lecz również weryfikuje wnioski uzyskane $\mathrm{z}$ autonomicznej analizy swych źródeł za pomocą wyników badań innych dyscyplin, niekoniecznie humanistycznych (por. Kara 2017).

Już tylko dla porządku przypomnijmy, iż współczesna archeologia - z racji realizowanej problematyki osadzona nie tyle w nurcie nauk historycznych, ile społeczno-historycznych - interpretuje pozyskiwane przez siebie źródła kopalne na podstawie własnego warsztatu badawczego, który przeszłość pozwala odtwarzać 
głównie w aspekcie społecznym oraz ideacyjno-kulturowym, a w koincydencji ze źródłami pisanymi, źródłami lingwistyki historycznej oraz danymi antropologii fizycznej - także w zakresie kulturowo-etnicznym. Swoje wnioski archeologia prezentuje przede wszystkim $\mathrm{w}$ ramach hipotez naukowych, słabiej lub silniej uargumentowanych, które w sposób świadomy lub bezrefleksyjny badacze formułują w zgodzie z przesłankami określonego paradygmatu naukowego. Wspomniane hipotezy stanowią tworzywo teorii, przy czym zasadność wniosków oraz metod ich formułowania są weryfikowane przez kolejne pokolenia badaczy w zgodzie z aktualnym stanem wiedzy fachowej, o czym pisaliśmy powyżej. Odtwarzana w ten sposób przeszłość kulturowa i przeszłość społeczna nie są tożsame z rekonstrukcją kompletnej rzeczywistości badanego odcinka dziejów, ze względu na przypadkowy oraz zazwyczaj „niemy” charakter źródeł archeologicznych tudzież ich fragmentaryczność. Wspomniane okoliczności decydują też o hipotetycznym wymiarze ustaleń archeologii, przy czym poziom ufności wniosków formułowanych przez archeologię/prahistorię wzrasta w miarę przyrostu informacji źródeł pisanych o badanym odcinku dziejów. Jakkolwiek przeszłość społeczna i kulturowa stanowiły system złożony, podlegający procesowi ciągłych przemian, to jednak archeologia w swych studiach nie odtwarza tegoż systemu jako strukturalnej całości, lecz przybliża jedynie jego fragmenty, w formie odtworzonych, statycznych układów funkcjonalno-przestrzennych. Układy te archeologia, w drodze rekonstrukcji, łączy zwykle w szersze struktury synchroniczne (horyzontalne) i/lub diachroniczne (wertykalne), które bada w określonych aspektach, m.in. pod względem chronologii, periodyzacji oraz funkcji, uzyskując w tym zakresie coraz lepsze wyniki.

Należy zaznaczyć, że przytoczona na początku artykułu konstatacja, w myśl której istnieje wyraźna zależność możliwości poznawczych archeologii od przyrostu nowoczesnych interpretacji źródeł kopalnych, nie jest już podzielana powszechnie, jak miało to miejsce $\mathrm{w}$ XX w., gdy problematyka naukowo-badawcza prahistorii czerpała inspiracje przede wszystkim z pozytywistycznych koncepcji teoriopoznawczych. Koncentrowały one uwagę badaczy na problematyce genezy znaleziska (także w wymiarze kulturowo-etnicznym), na jego substancjalnej (przedmiotowej) funkcji, jako przydatnego utylitarnie wytworu, na technologii i technice wykonania oraz na jego uwarunkowaniach społecznych. Niezależnie od zgłaszanej krytyki, głównie formułowanej przez archeologów będących pod wpływem postmodernizmu ${ }^{1}$, ujęcia źródłoznawczo-analityczne nadal pozostają bardzo popularne w archeologii i uznawane są (aczkolwiek w zmodyfikowanej formie, o czym poniżej) za niezbędne dla rozwoju tejże dyscypliny naukowej.

W tym kontekście odnotujmy czytelny we współczesnych studiach archeologicznych „renesans” zainteresowania znaleziskami wczesnośredniowiecznych grzebieni z obszaru Europy Północnej i Środkowo-Wschodniej - przedmiotów

${ }^{1}$ O kierunkach poznawczych w archeologii zob. Marciniak 2012, zwłaszcza s. 64 i n., tamże dalsza literatura. 
wykonanych z poroża lub kości, zwykle bardzo starannie, przeważnie też ornamentowanych. Wspomniane zainteresowania, o charakterze stricte naukowym, sięgają początkami przełomu lat 30. i 40. ubiegłego wieku. Wówczas opublikowane zostały bogate serie znalezisk wczesnośredniowiecznych grzebieni, które pochodziły z nieco wcześniej (lata 1934-1938) przeprowadzonych badań wykopaliskowych w Wolinie (obecnie Polska, woj. zachodniopomorskie) oraz w Hedeby/Haithabu (Niemcy, południowa Jutlandia), a także w Biskupinie na Pałukach (woj. kujawsko-pomorskie) oraz na tzw. Górze Lecha w Gnieźnie (woj. wielkopolskie) (zob. Rajewski 1938, 1939; Jankuhn 1943; Wilde 1953). Udostępniono również grzebienie pozyskane z XIX-wiecznych badań wykopaliskowych wczesnośredniowiecznych cmentarzysk na wyspie Björkö (jezioro Mälar, Szwecja-Uppland), które łączy się z ludnością odnotowanej w źródłach pisanych osady w Birce (Arbman 1940; 1943; B. Ambrosiani 1981)2. Zarówno w tych pracach, jak i w następnych, łącznie z najnowszymi pozycjami literatury fachowej (również polskiej), uwagę badaczy koncentrują przede wszystkim zagadnienia związane $\mathrm{z}$ typologią oraz datowaniem wczesnośredniowiecznych grzebieni (przedmiotów ujawniających temporalną zmienność formy oraz stylistyki), przy czym metrykę tych artefaktów coraz częściej weryfikuje się za pomocą wskazań dendrochronologii czy probabilistycznych przedziałów kalibrowanego wieku radiowęglowego. W tym przypadku datuje się próbki z reliktów archeologicznych, które wyznaczają funkcjonalno-stratygraficzny kontekst znalezisk ${ }^{3}$.

Wspomniane grzebienie uznaje się $\mathrm{w}$ związku $\mathrm{z}$ tym za tzw. niezależne wyznaczniki chronologii wczesnego średniowiecza, tudzież za identyfikatory określonych procesów społeczno-kulturowych i gospodarczych (zob. np. Hilczerówna 1961; Roes 1963; Tempel 1970; 1979; Cnotliwy 1973; 1993; 2013; K. Ambrosiani 1981; MacGregor 1985; MacGregor, Mainman, i Rogers 1999; Smirnova 2005; Ashby 2007; 2010; 2011; Sergeeva 2010; Zamelska-Monczak 2014). W tym przypadku chodzi przede wszystkim o procesy, które doprowadziły u zarania tzw. okresu wikińskiego, czyli najpóźniej w 2. połowie VIII w. ${ }^{4}$, do powstania na obszarze Europy Północnej i Środkowo-Wschodniej rozległej sieci osiedli rzemieślniczo-handlowych o genezie franko-fryzyjskiej i/lub skandynawskiej, z których część przekształciła się $\mathrm{z}$ czasem $\mathrm{w}$ polietniczne organizmy wczesnomiejskie

${ }^{2}$ W Wolinie, Haithabu i Birce odkryto pozostałości osiedli rzemieślniczo-handlowych (z czasem przekształconych w organizmy wczesnomiejskie), pochodzące ze starszych i młodszych faz wczesnego średniowiecza. W Biskupinie oraz Gnieźnie natrafiono m.in. na relikty grodów z czasów pierwszych Piastów, w tym z okresu budowy zrębów ich najstarszego państwa (władztwa).

3 Tego rodzaju weryfikacje, oparte na datowaniu próbek archeologicznych za pomocą akceleratorowej (AMS) metody pomiaru wieku izotopu węgla 14C, dokonano dla znalezisk z reliktów grodów wczesnopiastowskich z Gniezna, Poznania i Giecza, w związku z realizacja wspomnianego powyżej projektu badawczego NPRH. Monografia z wynikami projektu jest aktualnie przygotowywana do druku.

${ }^{4} \mathrm{~W}$ artykule chronologię okresu wikińskiego oraz datowanie jego trzech faz - określonych jako starszy, środkowy i młodszy okres wikiński - podajemy za Arwidsson (red.) 1984, s. 290; zob. też Jażdżewski 1967, tabela 5. 
z wyspecjalizowanymi nurtami rzemiosła stacjonarnego lub wędrownego (dotyczy m.in. rogownictwa i grzebiennictwa) $)^{5}$. $\mathrm{Z}$ tego powodu w kręgu dociekań archeologii pozostaje też technika produkcji grzebieni, jej organizacja (w tym obszary pozyskiwania surowców), jak również proweniencja tych przedmiotów, kierunki oraz zasięg ich rozprzestrzenienia, a także charakter dyfuzji (Cnotliwy 1973; 1993; 2013; Ulbricht 1978; K. Ambrosiani 1981; Weber 1993; MacGregor, Mainman i Rogers 1999; Smirnova 2005; Ashby 2009; 2013; Ashby i Batey 2012; van Riel 2017). W kontekście ostatniej uwagi odnotujmy, że dowiedziony przez archeologów związek określonych form grzebieni z etno-kulturowymi ugrupowaniami Skandynawów doby wikińskiej pozwala śledzić (oczywiście tylko $\mathrm{z}$ dozą prawdopodobieństwa i w pewnych sytuacjach) chronologię, kierunki, zasięg oraz charakter migracji przedstawicieli tegoż ludu we wczesnym średniowieczu. W nowszej literaturze przedmiotu podkreśla się również przydatność znalezisk grzebieni w badaniach elitarnej kultury państw Europy średniowiecznej. W tym przypadku grzebienie analizuje się pod kątem obecności w systemie kulturowo-społecznym, traktując jako wyznaczniki społecznego statusu (zob. Zamelska-Monczak 2014, s. 71-72).

Na marginesie wspomnianych rozważań pozostaje natomiast problematyka funkcji rejestrowanych archeologicznie grzebieni wczesnośredniowiecznych w ówczesnych systemach kulturowych europejskiego Barbaricum, interpretowanych jako systemy kulturowe homo symbolicus ${ }^{6}$. Dzieje się tak mimo istnienia w tym zakresie wiarygodnych i wartościowych poznawczo informacji ówczesnych źródeł pisanych oraz opracowań naukowych, które traktują o symbolice lub semantyce grzebieni, głównie okazów pradziejowych (Wilke 1915, s. 18 i n.; Helmers 1939;

5 Zob. Callmer 1995; Łosiński 2008, s. 37-40, 127-131, 143-169. W literaturze żywo dyskutowany jest problem udziału rogowników wędrownych w produkcji grzebieni prowadzonej w Europie Północnej wczesnego średniowiecza, głównie w okresie wikińskim, w tamtejszych ośrodkach wczesnomiejskich lub osiedlach rzemieślniczo-handlowych. Za istnieniem tego rodzaju relacji wyraźnie opowiedziała się K. Ambrosiani (1981). Wskazała na związek rogowników wędrownych z obsługą ściśle określonych targów sezonowych, które funkcjonowały w wymienionych ośrodkach. Według Ambrosiani wspomniane targi umożliwiały wędrownym wytwórcom nie tylko sprzedaż wyrobów, lecz również zakup surowca (zwłaszcza poroża). Koncepcja nie jest podzielana powszechnie. Polemicznie odniósł się do niej m.in. S.P. Ashby (2013, s. 196), dla którego „The model also proposes an unrealistic and unnecessary level of organisational uniformity; why should combmakers work in the same way, in all areas, at all times, irrespective of political, social, economic, or tenurial circumstance? / There is also a problem of scale: over what distances should we envision these combmakers moving? There is a realistic possibility that peripatetic combmakers worked on a circuit that took in York or Lincoln and their hinterlands, and one might perhaps accept the idea of seaborne combmakers travelling between the nodal towns of the Baltic as part of a community of travelling artisans and traders [...]. However, it seems unlikely that the combmakers from either region were in regular contact with their counterparts from across the North Sea".

6 Są to systemy kulturowe, które antropologia społeczna utożsamia ze wspólnotami tzw. tradycyjnymi. Uważa się, że charakteryzowała je mentalność „nieoswojona”, czyli sposób myślenia magiczno-mityczny, pozbawiony cech racjonalizmu człowieka „oświeconego” (zob. Lévi-Strauss 1969). Kryteria te spełniają również ludy tzw. barbarzyńskiej części Europy, zamieszkujące wymienione terytorium w starożytności i wczesnym średniowieczu (por. Modzelewski 2004). 
Buchholz 1984-1985; Muhl 1990, s. 131 i n.; Kwapiński 1998, s. 99 i n.; Kondrat'eva 1999; Gansum 2003).

W literaturze przedmiotu, także w publikacjach najnowszych, funkcję wczesnośredniowiecznych grzebieni przyjęło się uważać - w zgodzie z ustaleniami szwedzkiej archeolożki K. Ambrosiani (1981, s. 12-15) - za ekskluzywne, spersonifikowane przybory toaletowe względnie elementy stroju (swego rodzaju spinki do włosów). Uważa się, iż raz użyte - w przeciwieństwie do biżuterii czy elementów uzbrojenia (na przykład mieczów) - grzebienie nie były przekazywane w drodze spadku lub wymiany. W przypadku znalezisk grobowych podkreśla się związek grzebieni z bliżej nieokreślonym nurtem symboliki funeralnej, istotnej dla pogrzebu jako momentu przejścia ze świata doczesnego, czyli świata śmiertelnych, do zaświatów, czyli świata umarłych/ nieśmiertelnych (K. Ambrosiani 1981, s. 13; zob. też Rijkelijkhuizen 2011, s. 201-2027). Dodajmy, że stosowne informacje źródeł pisanych zostały w wymienionych pracach wykorzystane jedynie w sposób ilustracyjny.

W literaturze przedmiotu nie zostały - jak dotąd - podjęte poważniejsze próby analizy symbolicznych atrybucji interesujących nas grzebieni, jako przedmiotów, a zarazem społeczno-kulturowych znaków, nie licząc sygnalizowanego powyżej artykułu norweskiego archeologa T. Gansuma (2003) o włosach i grzebieniach jako symbolach władzy skandynawskiej arystokracji z przełomu starożytności i średniowiecza, a także cytowanego przyczynku badaczki rosyjskiej (Kondrat'eva 1999), w którym rozważono ogólne zagadnienia semantyki grzebieni. Nieufność badaczy wobec tego rodzaju analiz dziwi, zważywszy na potencjalne możliwości zastosowania w studiach nad ornamentyką grzebieni, zwłaszcza nad ich figuralnym zdobnictwem, zespołu metod analizy semiotycznej (semantycznej) ${ }^{8}$. W zakresie wspomnianej analizy archeolodzy dysponują już określonym doświadczeniem badawczym, które uzyskali, dokonując wartościowych poznawczo analiz semantycznych lub strukturalnych analiz semiotycznych (semiologicznych) w zakresie m.in. ikonografii pradziejowych urn tzw. twarzowych z obszaru ziem polskich czy iko-

${ }^{7}$ Przedstawione w cytowanej pracy ustalenia są zbieżne z poglądami K. Ambrosiani. M. Rijkelijkhuizen sugeruje jednak możliwość używania tego samego grzebienia przez członków kilku pokoleń. Powołuje się w tym przypadku na potwierdzone archeologicznie okazy naprawiane lub noszące ślady intensywnego użytkowania. Przytoczona argumentacja nie do końca przekonuje.

8 Informacje o ornamentyce wczesnośredniowiecznych grzebieni były dotychczas wykorzystywane głównie w kontekście analizy techniki wykonania, typologii, chronologii oraz pochodzenia wspomnianej kategorii znalezisk. Na tym tle wyróżnia się koncepcja angielskiego archeologa S.P. Ashby'ego (2013), sformułowana na podstawie analizy znalezisk wczesnośredniowiecznych grzebieni z Europy Północnej. Zakłada ona, iż wysoki poziom wykonania grzebieni - wraz z określoną formą oraz zdobnictwem tudzież standaryzacją okazów - stanowiły rodzaj firmowego znaku konkretnych wytwórców lub pracowni. Znak ów rozpoznawany był przez odbiorców jako handlowy znak jakości towaru. Ważna role w opisanym procesie komunikacji społecznej odgrywał ornament grzebienia, który musiał być starannie wykonany za pomocą określonych narzędzi oraz dostosowany do kształtu przedmiotu. Ze względu na brak sygnowania ówczesnych grzebieni imieniem wytwórcy, chociaż znane są również tego rodzaju odosobnione przypadki wykonane za pomocą pisma runicznego, o umiejętnościach rogownika oraz jego związkach z określoną grupą warsztatów świadczył sporządzony przez niego grzebień. 
nografii ekskluzywnych wytworów kultury skandynawskiej z okresu wędrówek ludów lub epoki wikińskiej (np. Düwel 1986; Ellmers 1986; Hauck K. 1986; Hedeager 1998; Kowalska 1998; A.P. Kowalski 1998; Kwapiński 1998; Marold 1998). W obu przypadkach wspomniane analizy specjalistyczne dostosowane zostały do specyfiki kontekstualnego źródła ikonograficznego, w obu posłużono się ujęciem hermeneutycznym ${ }^{9}$, wreszcie w obu nurtach analiz odwołano się m.in. do danych archeologii, antropologii kulturowej, szeroko pojmowanego religioznawstwa oraz mitologii ludów Europy i Azji, stosując w tym przypadku metodę badań komparatystycznych.

Zgodnie z obowiązującą w nauce (zwłaszcza w etnologii strukturalnej, w pewnym zakresie też w etnosemantyce/antropologii kognitywnej) zasadą pansemiotycznego traktowania wszystkich zjawisk kulturowych (Lévi-Strauss 1970; Burszta 1987a; 1987b) - jak też w zgodzie z ogólnym modelem semiologii w ujęciu R. Barthesa (1970; 2009), oraz odgrywającymi w tym przypadku rolę szczególną założeniami metody ikonologicznej według E. Panfosky'ego (1971) - w wyżej wymienionych opracowaniach (zwłaszcza dotyczących urn twarzowych), w pierwszej kolejności przeanalizowane zostały pod kątem informacji symbolicznych elementarne wątki ikonograficzne badanych struktur, uznane za znak kulturowy lub system znaków kulturowych (swego rodzaju kod), które - zanim przystąpiono do analizy symbolicznej - zostały sklasyfikowane ${ }^{10}$. Dopiero po sklasyfikowaniu znaków elementarnych lub systemu tychże znaków, oraz ustaleniu ich semantyki, przystąpiono do zasadniczego wątku analizy semiologicznej, czyli rozpoznania ich funkcji w ramach badanych struktur, w tym przypadku ikonologicznych. Dodajmy, iż wspomniane struktury - w semiologii oraz antropologii społecznej - uznaje się za nasycone symboliką fenomeny kultury, ułożone w pewnym porządku ideacyjnym. Jest to konstatacja ważna, ponieważ umożliwia rozszerzenie interpretacji naukowych o nowe wątki badawcze. Niezależnie od cząstkowego zakresu poznania porządku poszczególnych struktur badanej kultury pozwala bowiem poszerzyć za-

${ }^{9}$ Z lektury cytowanych prac wynika, iż autorów łączy przekonanie o niemożności poznania całej struktury bez zrozumienia szczegółu, a ten ostatni wymyka się naukowemu poznaniu, o ile nie zostanie odwołany do całości. Jest to zasada wpisująca się w założenia filozofii hermeneutycznej, gdzie figuruje pod pojęciem tzw. koła hermeneutycznego. W interesujących nas pracach obserwujemy też wyraźną obecność hipotez naukowych, a nawet domysłów.

${ }^{10}$ Według teorii semiologii, w systemach znaków kulturowych, tożsamych z systemami semantycznymi, ujawniają się bowiem dwa porządki logiczne: klasyfikacja znaków oraz ich symbolika, przy czym na system znaków składają się postawy o charakterze psychologicznym i społecznym, które integrują wspomniany system w sposób dynamiczny, w związku z czym nie funkcjonował on jako twór skończony, lecz był nieustannie konstruowany (Lévi-Strauss 1970, s. 96-97; zob. też Libera 1987, s. 116-117). Symbole można zatem ,porządkować”, łącząc je w różne systemy (struktury) semantycznych znaków, m.in. w układy wyznaczone przez tzw. opozycje binarne, co praktykują zwłaszcza członkowie tzw. tartusko-moskiewskiej szkoły semiotycznej (np. Toporow 2003). Wspomniane znaki cechuje bowiem wieloznaczność, ujawniająca się na różnych poziomach strukturalnych kultury. Dodajmy, że w myśl powyższych koncepcji znaki lub systemy znaków tkwią immanentnie w kulturze (m.in. w symbolicznej konotacji i/lub w micie), a tym samym w tradycyjnych systemach kulturowych nie mają one charakteru autonomicznego. 
kres naukowych dociekań, dotąd ograniczony do klasyfikacyjno-semantycznego nurtu analizy znaków kulturowych, o tzw. paradygmat mitologiczny. Prześledzenie zgodności wątków ikonograficznych, jak też całych struktur ikonologicznych, z danymi mitologii ludów indoeuropejskich (w przypadku wytworów kultury skandynawskiej przede wszystkim $\mathrm{z}$ danymi mitologii normańskiej epoki wikińskiej), przeprowadzone zwłaszcza pod kątem relacji z kosmologicznymi oraz eschatologicznymi wątkami mitologii określonych wspólnot, które informują o światopoglądzie ludu, poskutkowało nie tylko modyfikacją warsztatu naukowego archeologa. Przyczyniło się również (a może przede wszystkim) do włączenia się archeologów w szerszą dyskusję nauk społeczno-historycznych na temat sposobu myślenia ludów tzw. barbarzyńskich oraz wpływu mentalności społecznej na ich systemy kulturowe. Dzięki zastosowaniu powyższej metody oraz umiejętnemu wyborowi adekwatnych do niej źródeł archeologicznych uzyskano bowiem dane, które pozwalają archeologii ustalić hipotetyczny sens konkretnego wytworu w systemie społeczno-kulturowym. W tym celu zaleca się sięgnięcie do głębszych pokładów struktury symbolicznych znaczeń badanych artefaktów. Znaczenia te pozostają zwykle ukryte pod pokładem ,przedmiotowej (substancjalnej) kategoryzacji” wytworu. Pod tym terminem rozumie się zazwyczaj konwencjonalną (utylitarną) funkcję przedmiotu. Tym samym zastosowanie metody analizy semiotycznej (semantycznej) w studiach archeologii nad sensem (funkcją) pozyskiwanych przez nią źródeł kopalnych w odtwarzanych systemach kultury społecznej może przyczynić się do poszerzenia wiedzy o strukturze i charakterze tejże kultury - walorach rekonstruowanych przez archeologię. Może też skutkować wzrostem informacji o mentalności członków wspólnoty utożsamianej z badaną kulturą archeologiczną.

Uzyskanie tego rodzaju danych jest możliwe jedynie w sytuacji kompleksowego rozpoznania źródła archeologicznego, to znaczy łącznie z jego ścisłym kontekstem stratygraficzno-funkcjonalnym. W tym przypadku nieodzowna jest metoda wieloaspektowej analizy porównawczej, która w ramach hipotezy naukowej umożliwia ustalenie miejsca źródła w rekonstruowanym układzie społeczno-kulturowym.

Przypomnijmy, iż pod tym pojęciem archeologia rozumie zespół zmaterializowanych zjawisk, które odtworzone zostały metodą retrospektywną i porównawczą w formie diachronicznych oraz synchronicznych układów funkcjonalnych, tożsamych z kulturą tzw. archeologiczną. Układy te rozważa się na podstawie modeli teoriopoznawczych, w ostatnim czasie coraz częściej z uwzględnieniem tzw. współczynnika humanistycznego, który zaproponował w 1922 r. socjolog kultury F. Znaniecki (zob. Kurnatowska i Kurnatowski 2012, s. 24 i n., tamże dalsza literatura). W myśl definicji tegoż współczynnika kultura społeczna to struktura wielopoziomowa, złożona $\mathrm{z}$ faktów empirycznych, które tworzą określony ład zależny od czynników stwarzanych i utrzymywanych przez rzeczone fakty. Na tej podstawie zaleca się badania kultury w sposób systemowy, to znaczy w kontekście współczesnej jej rzeczywistości, co czyni m.in. antropologia historyczna. Dla naszych dociekań jest to konstatacja istotna, zważywszy na to, iż w świetle ustaleń etno- 
logii kultura badanych przez nią społeczeństw o mentalności tradycyjnej, zbliżona do kultury ludów europejskiego Barbaricum starożytności i wczesnego średniowiecza, nie jest podzielona na nurty autonomiczne, lecz tworzy jedność strukturalną, wynikającą z faktu przenikania się tzw. kultury symbolicznej (duchowej) z kulturą tzw. materialną (techniczną/użytkową). Wspomniane zjawisko dokonuje się zarówno w wymiarze egzystencji jednostki, jak i w wymiarze życia wspólnoty, nie zawsze w sposób świadomy (Lévi-Strauss 1969; w odniesieniu do kultury badanej przez archeologię zob. Kucypera i Wadyl 2012; Tabaczyński 2012).

W tym kontekście warto przywołać myśl wybitnego polskiego etnografa i etnologa K. Moszyńskiego, sformułowaną ponad 50 lat temu, która wydaje się istotna również ze względu na poczynione w niej uwagi natury badawczej: „Mówiąc najogólniej, kultura prymitywna to - nieomal chaotyczny splot, to - jak gdyby olbrzymie źródło, w którego ruchliwym wnętrzu wszczyna się już czy zapowiada sto osobnych nurtów, ale się jeszcze nie rozpływa w sto oddzielnych strug. [...] Walory magii, religii, sztuki, obrzędowości rodzinnej, różnych stron społecznego ustroju, techniki itd. zespalają się $\mathrm{w}$ obrębie prymitywnej kultury tak ściśle, że badacz musi je niejako rozrywać, aby zaprowadzić w tej dziewiczej plątaninie jaki taki ład, pozwalający na jej zgłębienie. Rozrywanie takie jest niezbędne; ale ani na chwilę nie wolno zapominać, że się go dokonało i jak się go dokonało. Nie wolno zapominać, że nasze podziały [na kulturę materialną i kulturę duchową dop. M.K.] są sztuczne, że dzielenie jako takie nie jest naszym celem, lecz służyć ma jedynie i wyłącznie do podkreślenia najcharakterystyczniejszych cech pewnych grup zjawisk w celu ich zrozumienia" (Moszyński 1968, s. 46).

Badaczowi, przystępującemu do semiotycznej (semantycznej) analizy źródła archeologicznego, musi więc towarzyszyć refleksja nad realnymi możliwościami wspomnianej metody, która winna też dotyczyć potencjalnych trudności związanych z jej realizacją $\mathrm{w}$ ściśle określonym przypadku badawczym. Czynnikiem niezbędnym jest zastosowanie odpowiedniego warsztatu naukowego. Ważna jest zwłaszcza umiejętność posługiwania się metodami studiów porównawczych w celu „krytycznego” korzystania $\mathrm{z}$ wyników nauk współpracujących $\mathrm{z}$ archeologią. Rudymentarnym warunkiem pomyślnej realizacji badań pozostaje jednak wybór źródła adekwatny do możliwości metody. Z praktyki badawczej archeologii wiadomo, że tylko niektóre znaleziska gwarantują istotny postęp poznawczy. Sądzimy, iż z tego rodzaju sytuacją mamy do czynienia $\mathrm{w}$ przypadku grzebienia wymienionego $\mathrm{w}$ tytule niniejszego artykułu. Czy jest to przekonanie zasadne, pozostawiamy ocenie Czytelnika.

Przedmiotem dociekań jest zatem ornamentowany grzebień z poroża odkryty na wczesnośredniowiecznej osadzie w Stroszkach (gm. Nekla, pow. wrzesiński, woj. wielkopolskie), będący znaleziskiem unikatowym nie tylko na ziemiach polskich. Do naukowego obiegu wspomniane znalezisko wprowadził M. Brzostowicz, który poświęcił mu artykuł, gdzie z perspektywy archeologa-mediewisty trafnie scharakteryzował ów zabytek, podkreślając m.in. jego wyjątkowy charakter oraz szczególne znaczenie dla archeologii wczesnego średniowiecza (Brzostowicz 1996). 
W podsumowaniu stwierdził, iż „Obecność - zajmującego naszą uwagę - grzebienia na osadzie w Stroszkach należy odczytywać jako kolejne świadectwo kontaktów wielkopolsko-pomorskich. Proponowana przeze mnie chronologia [2. połowa IX-1. połowa X stulecia - dop. M.K.] tego wyrobu przeczy raczej obecności samych Skandynawów, którzy w tym czasie [...] ograniczali penetracje ziem polskich jedynie do południowych wybrzeży Bałtyku. Do Wielkopolski liczniej zaczęli ściągać dopiero w okresie umacniania się państwa wczesnopiastowskiego [...], tj. po połowie $\mathrm{X}$ w. [...] Kończąc [...] należy jeszcze raz podkreślić duży walor poznawczy omawianego zabytku" (Brzostowicz 1996, s. 272).

Wnioski sformułowane przez dr. M. Brzostowicza nie budzą naszych zastrzeżeń; nie podzielamy jedynie poglądów dotyczących pochodzenia odkrytego grzebienia. Do podjęcia tematu skłoniły nas jednak inne przesłanki. Rzecz dotyczy ustaleń cytowanego artykułu, których treść warto naszym zdaniem poszerzyć o interpretacje odnoszące się zwłaszcza do funkcji (sensu) oraz semantyki kulturowej opisanego znaleziska. Pozwalają one odkryty grzebień przenalizować w kontekście uwarunkowań mentalnych i kulturowych ludności wczesnośredniowiecznego Barbaricum europejskiego. Posłużyliśmy się w tym celu formułą studium tzw. przypadku, w której zabytek rozpatruje się w różnych aspektach badawczych i kontekstach kulturowych. Punktem wyjścia tego typu badań jest weryfikacja chronologii oraz proweniencji znaleziska jako historycznego źródła kopalnego.

I

Interesujący nas grzebień odkryto podczas ratowniczych badań archeologicznych wczesnośredniowiecznej osady tzw. otwartej w Stroszkach (stan. 1), położonej w zachodniej Polsce, w dorzeczu środkowej Warty, w południowej części centralnej Wielkopolski, około $3 \mathrm{~km}$ na północny wschód od grodziska w Gieczu (ryc. 1). Stanowisko badane było w latach 1982-1986 i 1999-2001 przez Muzeum Archeologiczne w Poznaniu (dalej jako MAP); wykopaliskami kierowały archeolożki mgr A. Gałęzowska oraz mgr E. Stelmachowska. W literaturze przedmiotu odsłonięte pozostałości fragmentu osady (ponad 60 obiektów: tzw. ziemianki, jamy, paleniska, dołki posłupowe - stwierdzone w południowej części stanowiska o powierzchni powyżej 0,84 ha) datowane są orientacyjnie bądź na fazy B-C lub B-C/D, bądź na fazy B-D wczesnego średniowiecza w Wielkopolsce, czyli w zgodzie $\mathrm{z}$ ramowym datowaniem wymienionych faz - na okres od około VII do początku 2. połowy X wieku (Informator Archeologiczny: 1983, s. 170-171; 1985 , s. $110 ; 1986$, s. 109 ; 1987, s. 105 ; Kurnatowska, Losińska 1990, s. 147 , nr 5; Gałęzowska 2005, s. 285) ${ }^{11}$. Wnosząc z datowania, lokalizacji oraz charak-

${ }^{11}$ Zgodnie z nowszymi ustaleniami, dotyczącymi periodyzacji oraz chronologii wczesnego średniowiecza w dorzeczu Warty w ujęciu archeologicznym, faza $\mathrm{D}_{0}$ (około 900-950/960) jest tożsama z pierwszym (najstarszym) stadium państwa piastowskiego. Została wyróżniona na obszarze centralnej 

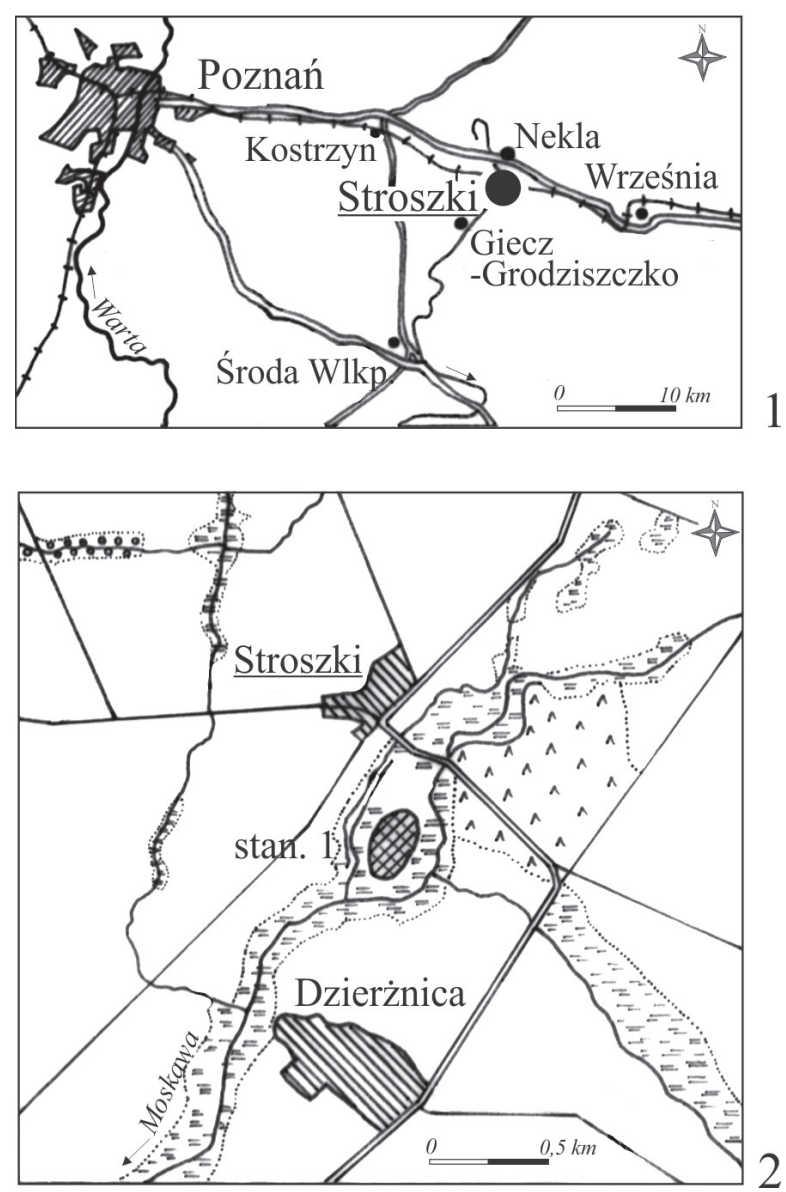

Ryc. 1. Stroszki, stan. 1, gm. Nekla, woj. wielkopolskie. Lokalizacja (1) i położenie (2) stanowiska archeologicznego (relikty wczesnośredniowiecznej osady tzw. otwartej). Według Brzostowicz 1996, ryc. 1 (z modyfikacją). Przerys. M. Śniedziewska-Lerczak i J. Sawicka

Wielkopolski, a konkretnie na terenie Wysoczyzny Gnieźnieńskiej oraz Pojezierza Poznańskiego z ich najbliższą peryferią (Kara 2009, s. 229 i n.). Na tym terytorium faza $\mathrm{D}_{0}$ zastąpiła fazę C, której w centralnej Wielkopolsce archeologia nie wyróżnia, aczkolwiek nie jest to zasada przestrzegana powszechnie. Obecność fazy C (około 850/900, głównie 880/900-950/1000) przyjmuje się natomiast dla obszarów Wielkopolski otaczających Wysoczyznę Gnieźnieńską z Pojezierzem Poznańskim. Wraz z wcześniejszymi od niej fazami A-B jest tam synchronizowana z tzw. plemiennymi modelami kultury. Stricte wczesnopaństwowy model kultury reprezentuje na tym obszarze dopiero faza $\mathrm{D}_{1}$ (około (około 950/960-980/990 oraz faza $\mathrm{D}_{2}$ (około 990-1050), które notuje się również w centralnej Wielkopolsce, jako następne w kolejności po stadium $\mathrm{D}_{0}$. Dodajmy, iż na terenie centralnej Wielkopolski fazę $\mathrm{D}_{0}$ poprzedza ,plemienna” faza $\mathrm{B}$, która jest fazą długiego trwania (około 600/650-850/900) (Kara 2016, s. 108). 
teru kultury mieszkańców, wspomniana osada w młodszym stadium funkcjonowania (2. połowa lub raczej koniec IX-początek 2. połowy X stulecia) wchodziła w skład północnej części gieckiego okręgu grodowego (Krysztofiak 2016, s. 120, 142). Przypomnijmy, że ideowo-kultowe, polityczno-administracyjne, gospodarcze oraz militarne centrum tegoż układu wyznaczał gród w Gieczu, zbudowany w latach 60. IX w. na wcześniejszym korzeniu osadniczym (Krąpiec i Krysztofiak 2003; Krysztofiak 2007; 2009; 2016). Jest to najstarszy ewentualnie jeden z najstarszych grodów wczesnośredniowiecznych na obszarze centralnej Wielkopolski, metryką budowy wyprzedzający warownie w Gnieźnie i Poznaniu, wzniesione dopiero w 1. połowie X stulecia (Kurnatowska 2002, s. 66 i n.; Kara 2009, s. 282 i n.; 2010) (ryc. 2) ${ }^{12}$. Według informacji zawartej w spisanej na początku XII w. przez

12 Nie wszystkie grodziska wczesnośredniowieczne z obszaru centralnej Wielkopolski ujawniają dobry stan rozpoznania archeologicznego, porównywalny ze stanem badań reliktów ośrodka grodowego w Gieczu. Z tego powodu sformułowaliśmy powyżej zastrzeżenie, dotyczące chronologii grodu gieckiego.

W przypadku najstarszego grodu na poznańskim Ostrowie nie można wykluczyć, iż funkcjonował on już w IX w., aczkolwiek brak w tym zakresie pewniejszych dowodów. Za weryfikacją dotychczasowej chronologii obiektu przemawiają kalibrowane datowania 14C próbek archeologicznych z zespołu jam, wykonane metodą akceleratorową w Poznańskim Laboratorium Radiowęglowym (nr pracy 9645/2015, 10970/2016) w ramach wymienionego wyżej projektu badawczego NPRH. Jamy (są to pozostałości obiektów użytkowych zagłębionych w podłoże) wpisują się w najstarszy, częściowo odłożony bezpośrednio na calcu, a częściowo naruszający jego strukturę, układ stratygraficzno-funkcjonalny, odkryty w podziemiach obecnej katedry biskupiej i wyróżniony jako warstwa kulturowa nr VI z jamami. Wspomniana warstwa wraz z zalegającą na niej warstwą kulturową nr V, w obrębie której stwierdzono relikty drewnianych budynków zrębowych o funkcji zapewne mieszkalnej, stanowiła podłoże dwu kolejnych świątyń chrześcijańskich (kościoła z baptisterium oraz młodszej od nich preromańskiej bazyliki w typie ottońskim), które wzniesiono w tym miejscu w 2. połowie X w. (charakterystyka źródeł: Pieczyński 1962, s. 246 i n. [warstwy IV-VI]; Józefowiczówna 1963, s. 33 i n., 123 i n. [warstwy IV-VI]; wyniki reanalizy źródeł: Kóčka-Krenz, Kara i Makowiecki 2004, s. 132 i n.; Kurnatowska, Kara 2004; Kara 2009, s. 229, przypis 1291, s. 245, przypis 1324, s. 255 i n.).

Dla warstwy nr VI uzyskano następujące datowania bezwzględne:

jama nr 1: próbka nr P-katedra 1954-10 (nr lab. Poz-71230, kościany tzw. kolec, głębokość minus 4,1 m) - data 14C: 1210+/-30 B.P., probabilistyczne przedziały wieku kalibrowanego z prawdopodobieństwem wyniku i poziomami jego ufności: cal. A.D. 771-780 (68,2\% / 6,3\%), 788-875 (68,2\% / 61,9\%), 695-700 (95,4\% / 0,6\%), 710-745 (95,4\% / 10,8\%), 764-891 (95,4\% / 83,9\%);

jama nr 1: próbka nr P-katedra 1954-11 (nr lab. Poz-71231, tzw. kolec z poroża, głębokość minus 4,12 m) - data 14C: $1175+/-30$ B.P., probabilistyczne przedziały wieku kalibrowanego $\mathrm{z}$ prawdopodobieństwem wyniku i poziomami jego ufności: cal. A.D. 777-793 (68,2\% / 11,1 \%), 801-890 (68,2\% / 57,1\%), 770-902 (95,4\% / 84,4\%), 919-963 (95,4\% / 11,0\%);

jama nr 2: próbka nr P-katedra 1954-21 (nr lab. Poz-81472, fragment dziegciu z naczynia dziegciarskiego, głębokość minus 4,1 m) - data 14C: 1200+/-30 B.P., probabilistyczne przedziały wieku kalibrowanego z prawdopodobieństwem wyniku i poziomami jego ufności: cal. A.D. 775-779 (68,2\% / 3,4\%), 788-873 (68,2\% / 64,8\%), 715-744 (95,4\% / 6,2\%), 765-895 (95,4\% / 87,8\%), 928-940 $(95,4 \% / 1,4 \%)$.

Z wymienionymi datami radiowęglowymi nie kolidują wyniki analizy chronologicznej materiału zabytkowego (w tym zespołów ceramiki naczyniowej) z warstwy kulturowej nr VI oraz towarzyszących jej jam, które są typowe dla fazy $\mathrm{D}_{0}$ według M. Kara (2009). W przypadku Poznania, wnosząc $\mathrm{z}$ datowania podobnych zespołów naczyń, odkrytych w nienaruszonych warstwach bogato staryfikowanych osiedli północnego Połabia (głównie części tzw. wieleckiej) i Pomorza Zachodniego (por. Kara 2009, s. 229, przypis 1291 , s. 255, 257, przypis 1374, tamże dalsza literatura; Łosiński 2008, s. 107 i n., tab. 1 [typy G-J]), rysują się przesłanki do rozszerzenia dolnej granicy orientacyjnego przedzia- 
Galla Anonima (I.8) pierwszej kronice polskiej, wymienione grody tworzyły - wraz z warownią we Włocławku (Władysławiu) na wschodnich Kujawach - grupę głównych, tzw. centralnych grodów Bolesława Chrobrego (panował w latach 992-1025), które zapewniały mu potęgę militarną, co nadawało jego władzy wymiary realne, a jednocześnie podnosiło prestiż, także $\mathrm{w}$ regionie ${ }^{13}$.

Dla naszych rozważań fundamentalne znaczenie ma odkryta w Stroszkach owalna jama nr 164, w obrębie której zalegał analizowany grzebień (zabytek w zbiorach MAP, znany nam $\mathrm{z}$ autopsji ${ }^{14}$ ). Obiekt, o wymiarach około $1,8 \times 1,1 \mathrm{~m}$ i maksymalnej głębokości około 0,3 m, wypełniony w większości brunatnym piaskiem, z wyraźnymi śladami spalenizny w części wschodniej, stanowił najprawdopodobniej pozostałość większego domostwa (Brzostowicz 1996, s. 269). Z jamy pozyskano kilkadziesiąt fragmentów glinianych naczyń ręcznie lepionych i częściowo obtaczanych na wolnoobrotowym kole garncarskim, które w zakresie techno-stylistycznym nawiązują do zespołów ceramiki naczyniowej, charakterystycznych dla obszaru centralnej Wielkopolski w fazach $\mathrm{B} / \mathrm{D}_{0}-\mathrm{D}_{0}$ wczesnego średniowiecza (koniec IX-3. ćwierć X w.).

Współwystępował z nimi uszkodzony, jednorzędowy grzebień złożony z trzech warstw płytek wyciętych z poroża, z których zewnętrzne - lite i półowalne w przekroju poprzecznym, stanowiące boczne okładziny grzebienia, będące zarazem jego uchwytem - mają lekko łukowaty grzbiet, wklęsłą podstawę oraz nieznacznie rozszerzone i zaokrąglone końce zadarte „rożkowato” (ryc. 3:1). Do wykonania okła-

łu wieku zespołów ceramiki z warstwy nr VI na koniec IX ewentualnie przełom IX i X wieku. Dodajmy, iż górny pułap przedziału należy umieszczać w 1. połowie X stulecia, tym razem w zgodzie z proponowaną w literaturze przedmiotu ramową chronologią fazy $D_{0}$ (około 900-950/960; patrz przypis $11 \mathrm{w}$ niniejszej pracy). Na ten czas można więc ostrożnie datować początki odkładania się ,,poznańskiej" warstwy nr VI, z zastrzeżeniem, iż procesy sedymentacyjne trwały również na początku $\mathrm{X}$ stulecia, co wynika $\mathrm{z}$ analizy stratygraficznej badanych reliktów osadniczych. Zespoły ceramiki naczyniowej z warstwy kulturowej nr V, która zalegała bezpośrednio na sedymencie nr VI, są bowiem typowe dla fazy $\mathrm{D}_{0}$. Z braku bezpośrednich relacji przestrzennych, wskazujących jednoznacznie na związek datowanych radiowęglowo jam z warstwy nr VI z odkrytymi na tym stanowisku pozostałościami drewniano-ziemnego wału grodu, w tym z reliktami najstarszej (?) fazy tegoż obwarowania, nie sposób jednak rozstrzygnąć, czy wspomniane jamy wiązały się z horyzontem działań antropogenicznych poprzedzających budowę ośrodka grodowego na poznańskim Ostrowie, czy dopiero z prymarną fazą grodu. Ze zwęglonej, źle zachowanej konstrukcji zewnętrznej wyżej wymienionego wału pochodzą 2 próbki drewna dębu (Quercus sp.), oznaczone metodą dendrochronologiczną przez M. Krąpca (Pracownia Dendrochronologiczna Akademii Górniczo-Hutniczej w Krakowie): po A.D. 897 i po A.D. 936 (Kóčka-Krenz, Kara i Makowiecki 2004, s. 134, ryc. 7 [dendrodaty: nr 1]).

O ile funkcjonowanie poznańskiego grodu w 1. połowie X stulecia nie budzi naukowych wątpliwości, o tyle IX-wieczna metryka budowy tegoż obiektu pozostaje nadal kwestią otwartą (por. Kóčka -Krenz 2008), aczkolwiek niepozbawioną prawdopodobieństwa.

13 Włocławek mógł zostać włączony w obręb wspomnianej struktury grodów dopiero w drugim państwie piastowskim. Wyrażono nawet przypuszczenie (Bieniak 1963, s. 30, przypis 21), że wskutek błędu kopisty, w rozpatrywanym wersie Kroniki polskiej Galla Anonima winien figurować Ostrów Lednicki zamiast Włocławka, co jednak jest wątpliwie (z nowszych ustaleń dotyczących wczesnopiastowskiego grodu we Włocławku zob. Banaszkiewicz 2016; Michałowski 2016b).

${ }^{14}$ Z grzebieniem zapoznaliśmy się w 1995 r. dzięki uprzejmości Kolegi M. Brzostowicza z MAP, za zgodą ówczesnego dyrektora placówki śp. prof. dr. hab. L. Krzyżaniaka. 


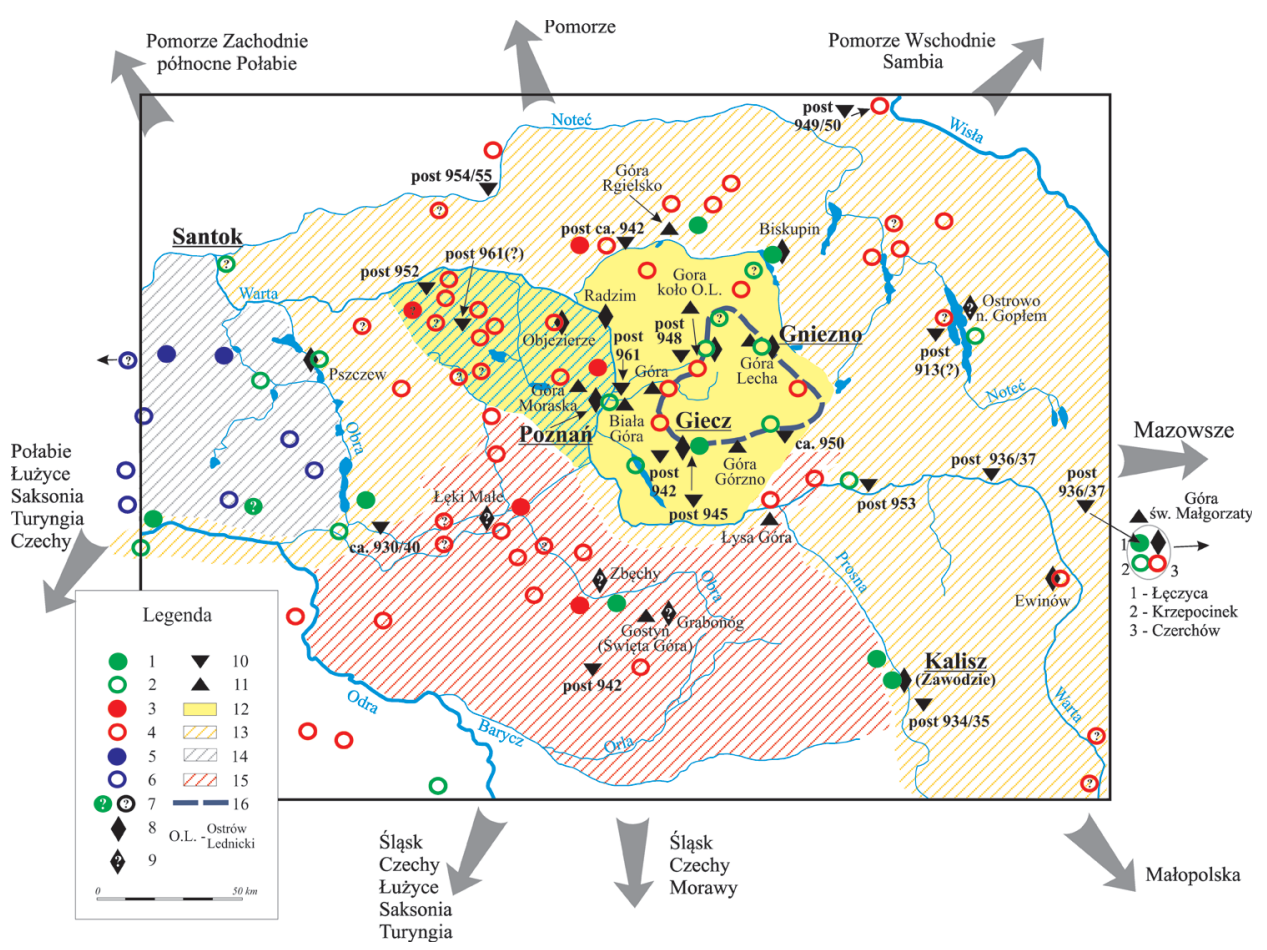

Ryc. 2. Grodziska i domniemane miejsca obrzędowo-kultowe $\mathrm{z}$ fazy $\mathrm{C}$ (koniec IX - 1. połowa $\mathrm{X}$ w.) oraz z fazy $\mathrm{D}_{0}(1$. połowa $\mathrm{X}$ - początek 2. połowy $\mathrm{X}$ w.) wraz z najstarszymi w dorzeczu Warty wczesnośredniowiecznymi skarbami srebra siekanego, na tle ustalonego archeologicznie zasięgu najstarszej domeny Piastów (1. połowa X - początek 2. połowy X w.), zasięgu obszarów powiązanych politycznie z wymienioną domeną (tzw. strefa kolaboracji) oraz zasięgu ziem podbitych przez Piastów najpóźniej około połowy X w. Według Kara 2009, ryc. 86 (z modyfikacją ). Przerys. J. Sawicka

Legenda: 1 - gród funkcjonujący po roku 950, zbudowany w starszych fazach wczesnego średniowiecza; $\mathbf{2}$ - gród funkcjonujący po roku 950, zbudowany w końcu IX lub na początku X w.; 3 - gród przestający funkcjonować najpóźniej około połowy X w., zbudowany w starszych fazach wczesnego średniowiecza; 4 - gród z końca IX - 1. połowy X w. lub z 1. połowy (zasadniczo 2. ćwierci) X - początku 2. połowy $\mathrm{X}$ w. (te ostatnie tylko w obrębie centralnej Wielkopolski, przede wszystkim Wysoczyzna Gnieźnieńska); 5 gród przestający funkcjonować najpóźniej na przełomie X i XI w., zbudowany w starszych fazach wczesnego średniowiecza; 6 - gród przestający funkcjonować najpóźniej na przełomie X i XI w., zbudowany w końcu IX lub na początku X w.; 7 - chronologia niepewna; 8 - domniemane miejsce obrzędowo-kultowe; 9 - jak wyżej, lecz chronologia niepewna; 10 - skarb dirhemów z metryką ukrycia; 11 - domniemana góra sakralna z historyczną lub obecną nazwą własną; 12 - zasięg najstarszej domeny patrymonialnej Piastów wraz z tzw. segmentem poznańskim przyłączonym do domeny $\mathrm{w}$ 1. połowie $\mathrm{X}$ w. (obszar szrafowany); $\mathbf{1 3}$ - strefa tzw. kolaboracji z władztwem piastowskim (tereny inkorporowane przez Piastów najpóźniej około połowy X w.); 14 - jak wyżej, lecz inkorporacja dopiero około X/XI w.; 15 - strefa podbojów piastowskich (tereny inkorporowane najpóźniej około połowy X w.); 16 - tzw. gnieźnieński układ (łańcuch) grodów z fazy $\mathrm{D}_{0}$ (w tej grupie tylko Giecz zbudowany w IX w.) 

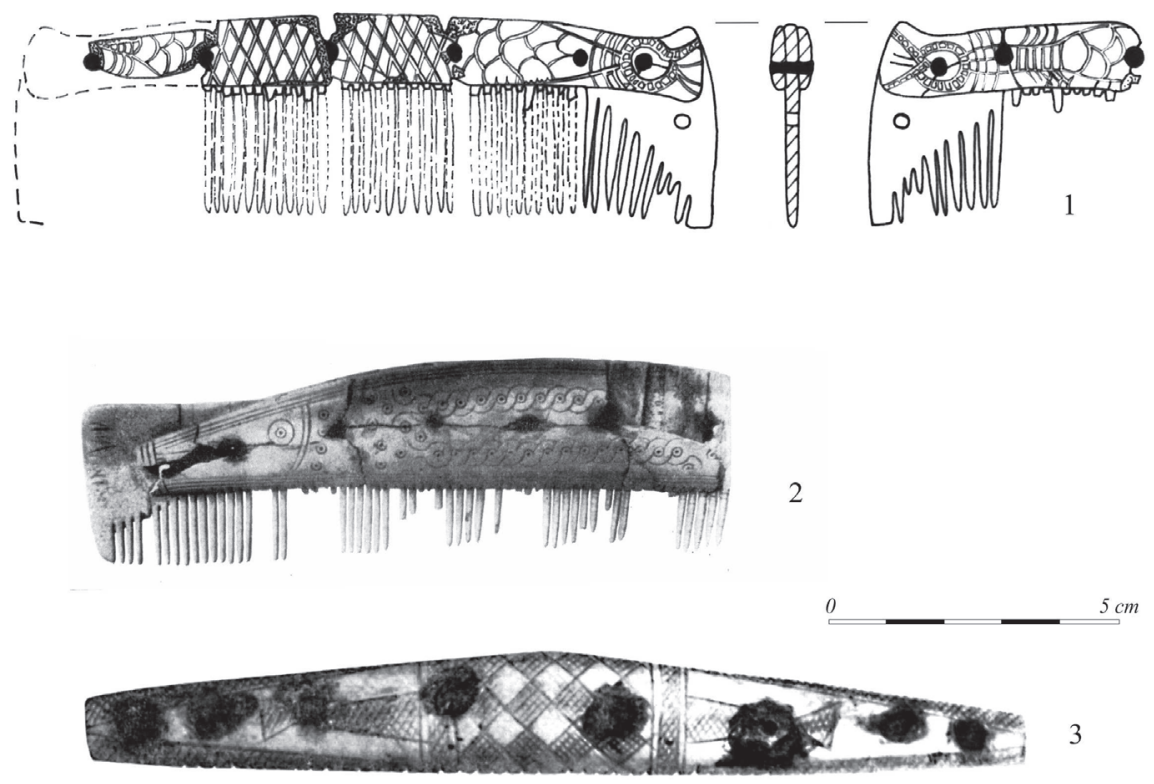

Ryc. 3. Wczesnośredniowieczne grzebienie z poroża: 1 - znaleziony na stanowisku nr 1 w Stroszkach pod Gieczem, w obiekcie nr 164; 2-3 - odkryte na obszarze Fryzji (Holandia). Oprac. M. Kara na podstawie: 1 - Brzostowicz 1996, ryc. 2; 2-3 - Roes 1963, tabl. XXIV:3;

XXXII:3. Przerysowanie i digitalizacja M. Śniedziewska-Lerczak oraz J. Sawicka

dzin oraz płytek tzw. zębatych (pierwotnie grzebień miał ich co najmniej pięć) użyto piłki, noża oraz pilnika. Piłką wycięto m.in. zęby w płytkach zębatych, co uczyniono jednak dopiero po zmontowaniu grzebienia i uprzednim naniesieniu zdobnictwa na jego okładziny boczne. Świadczą o tym wykonane wspomnianym narzędziem nacięcia, które widnieją na krawędzi podstawy jednej z bocznych okładzin i nieznacznie naruszają jej ornament. Pilnikiem wyrównano natomiast powierzchnie elementów składowych okazu. Okładziny boczne zespolono z wyżej wymienionymi płytkami zębatymi za pomocą sześciu niewielkich żelaznych nitów, starannie rozklepanych młoteczkiem, które rozmieszczono w przybliżeniu poziomo, bez wyjątku na styku między płytkami zębatymi. Część nitów nieznacznie narusza ornament, pokrywający obie okładziny boczne grzebienia, co dowodzi, iż zdobnictwo wykonano przed montażem wspomnianych okładzin z płytkami tzw. zębatymi. Zastosowana w przypadku grzebienia ze Stroszek metoda nitowania elementów składowych w jednorzędowy grzebień trójwarstwowy - łącznie z zaobserwowaną kolejnością wykonania poszczególnych elementów tegoż grzebienia oraz kolejnością 
ich montażu (najpierw sporządzono okładziny boczne ze zdobnictwem, następnie zespolono je $\mathrm{z}$ tzw. płytkami zębatymi za pomocą nitów, na koniec wycięto we wspomnianych płytkach zęby i wypolerowano grzebień zapewne szmatką lub kawałkiem wyprawionej skóry) - ma wyraźne odniesienia w materiale archeologicznym z wczesnego średniowiecza. W literaturze przedmiotu analogiczną metodę nitowania grzebieni opisuje się jako metodę every edge, czyli „na każdej krawędzi/na każdym styku płytki zębatej” (Ashby 2013, s. 201, ryc. 12.4b). Także pozostałe techniki użyte przy produkcji grzebienia ze Stroszek są typowe dla grzebiennictwa wczesnośredniowiecznej Europy (por. Cnotliwy 1973, s. 23 i n.; Ulbricht 1978, s. 25 i n.).

Dodajmy, iż na skraju zewnętrznej płytki zębatej grzebienia ze Stroszek widnieje otwór o średnicy około $0,3 \mathrm{~cm}$, starannie wywiercony świderkiem. W otworze tkwić mógł rzemień, służący do zawieszania przedmiotu na szyi lub u pasa. W literaturze przedmiotu podkreśla się jednak, iż tego rodzaju otwory służyły przede wszystkim do stabilizowania grzebienia we wnętrzu ochronnej pochewki, wykonanej z poroża lub kości, z którą grzebień tworzył funkcjonalny i stylistyczny zespół. Przed wysunięciem z pochewki grzebień chroniła najprawdopodobniej zatyczka organiczna, wetknięta w rząd trzech otworków, z których środkowy wywiercony był w skrajnej płytce zębatej grzebienia, a dwa przeciwległe w skrajnej części okładzin bocznych pochewki. Tego rodzaju sytuację sugerują znaleziska z Europy Północnej i Wschodniej (Björkö/Birka - środkowa Szwecja; Nowogród - północna Rosja), datowane na środkowy i/lub młodszy okres wikiński (generalnie X-połowa XI w.), czyli podobnie jak okaz ze Stroszek, o czym poniżej (zob. Arbman 1940, tabl. 163:1, 3, 5; Smirnova 2005, s. 18, 19, 44, ryc. 3.1; 3.2; 3.26) ${ }^{15}$. W przypadku grzebienia ze Stroszek nie stwierdzono jakichkolwiek pozostałości jego zabezpieczenia.

Płaszczyznę obu okładzin bocznych wspomnianego grzebienia (partia uchwytu) wypełniają analogiczne motywy ryte, naniesione starannie nożem lub rylcem. Wątek centralny przedstawia dużą, stosunkowo realistycznie odwzorowaną rybę, widoczną z profilu, pokrytą rzędem łusek i przesłoniętą pośrodku gęstą, ukośnie zarysowaną kratką, wyobrażającą sieć. Płetwa ogonowa ryby, niestety, zachowana tylko na jednej okładzinie grzebienia, ma poważnie zniekształconą formę. W związ$\mathrm{ku} \mathrm{z}$ tym wizerunek przypomina również raka widzianego z góry. Rybę flankują stylizowane głowy zwierzęce (dochowały się tylko dwie) z jęzorem w otwartej

\footnotetext{
15 Warto odnotować, że niektóre grzebienie odkryte na cmentarzyskach w Björkö/Birce, zaopatrzone w ochronną pochewkę z poroża, prawdopodobnie zawieszone były u pasa osoby zmarłej. Dodajmy, iż tamtejsze grzebienie $\mathrm{z}$ pochewkami stwierdzone zostały tylko $\mathrm{w}$ grobach męskich, natomiast w pochówkach uznanych za żeńskie wśród zdeponowanych grzebieni notuje się również umieszczone w skórzanych woreczkach lub torebkach. Kwestie te omawia K. Ambrosiani (1981, s. 14). Sa to uwagi istotne dla naszych rozważań. Należy jednak pamiętać, iż płeć osób pochowanych na cmentarzach w Björkö/Birce określona została na podstawie cech inwentarzy grobowych, co skłania do ostrożności. Wykonane oznaczenia płci są ostatnio kwestionowane na podstawie wyników analiz antropologicznych zachowanych szczątków ludzkich oraz badań kopalnego DNA, przynajmniej w odniesieniu do niektórych pochówków (zob. Hedenstierna-Jonson i in. 2017; Price i in. 2019).
} 
paszczy, ujęte - podobnie jak ryba - z profilu. Umieszczono je w „rożkowato” rozszerzających się końcach obu okładzin bocznych grzebienia. Zarówno ryba, jak i głowy zwierzęce mają wyraźnie zaznaczone oko, które każdorazowo imituje owalna główka jednego z sześciu nitów spajających grzebień. Ryba, domniemany rak, a być może również wspomniane głowy zwierzęce zostały wyobrażone w odmętach wody, konkretnie w pełnej dynamizmu toni jeziora bądź w nurcie rzeki, bądź w poruszanym bałwanami morzu. Obecność wspomnianego żywiołu - na co uwagę zwrócił M. Brzostowicz (1996, s. 270) - symbolizuje para trzech łukowatych linii, rozlokowanych na krańcach obu okładzin grzebienia. Linie przypominają rozchodzące się fale. Na pysk ryby oraz ogon raka zostały naniesione celowo; najprawdopodobniej próbowano w ten sposób zaznaczyć „istotę” toni wodnej jako żywiołu niebezpiecznego, pełnego poruszających się w nim stworów. Zdobnictwo, zgodnie z obowiązującą w społecznościach tradycyjnych ,artystyczną” zasadą horror vacui, całkowicie wypełnia powierzchnię obu okładzin bocznych grzebienia. Motywy - przedstawione na jednej osi, powiązane w swoisty łańcuch wyobrażeń - zostały niemal bez wyjątku ujęte z profilu, domniemany bowiem wizerunek raka, mimo uwidocznienia z góry, nie wyłamuje się z kompozycji dzięki zastosowaniu tzw. perspektywy skrętnej. $Z$ odnotowanego powyżej faktu naruszenia ornamentu obu okładzin bocznych grzebienia przez nity (zwłaszcza ukośnej kratki, wyobrażającej sieć, oraz rybich łusek) należy domyślać się, iż ornament grzebienia był elementem przedmiotu ważnym dla wytwórcy, a zapewne też użytkownika, przede wszystkim jako znak posiadający określone konotacje symboliczne. „Artystyczne” walory przedmiotu nie były jednak bez znaczenia. Nanosząc ornamentykę, uwzględniono bowiem miejsca na nity, w związku czym motywy zdobnicze uległy uszkodzeniu tylko w znikomym zakresie.

Technika oraz charakter wykonania grzebienia - wyrób staranny, sporządzony za pomocą specjalistycznych narzędzi, takich jak piłka, pilnik, rylec, świderek, młoteczek tzw. jubilerski - pozwalają lokować zabytek w grupie ekskluzywnych produktów rzemiosła rogowniczego. Za taką klasyfikacją przemawia też kompozycja układu zdobniczego grzebienia, dobrze dostosowana do formy przedmiotu. Wskazuje ona na opanowanie przez wytwórcę zasady harmonijnego łączenia motywów geometryczno-zwierzęcych, mimo przedstawienia ich w różnych perspektywach.

Grzebień ze Stroszek wykazuje najwięcej zbieżności z grzebieniami typu IB-VIII-1a według E. Cnotliwego (1973, s. 149-152; 2013, s. 75-76, ryc. 41; tak też Brzostowicz 1996), datowanymi na IX/X-X/XI stulecie, przy czym okazy wymienionego typu są tożsame $\mathrm{z}$ typem (grupą) 4 według W.D. Tempela (1970), z typem B1:2 wprowadzonym do literatury przez K. Ambrosiani (1981, ryc. 9; 1984, s. 169-176), z typem 6 według S.P. Ashby (2007), a częściowo także z typem „Birka” wyróżnionym przed ponad 25 laty przez E. Cnotliwego (1993, s. 359, ryc. 16). $Z$ okazami wspomnianych typów łączy go podobna forma (rozszerzone i zadarte „rożkowato” zakończenia okładzin bocznych), wymiary (długość około $11,5 \mathrm{~cm}$; maksymalna wysokość $3,5 \mathrm{~cm}$; maksymalna grubość $0,7 \mathrm{~cm}$; wysokość 
okładziny do 1,2 cm; grubość okładziny do $0,2 \mathrm{~cm}$; grubość płytki zębatej $0,2 \mathrm{~cm}$ ), charakter oraz technika wykonania, a także elementy zdobnictwa w postaci rytej, ukośnej kratki naniesionej regularnie w obrębie centralnej partii okładziny bocznej, która wraz z przeciwległą, zachowaną szczątkowo (brak m.in. części zdobionej zapewne wspomnianym motywem kratki), łącznie stanowiły uchwyt grzebienia. Jak dotąd nie odkryto okazu typu IB, odmiany VIII, z ornamentem analogicznym do znaleziska wielkopolskiego.

W świetle ustaleń E. Cnotliwego (1973, s. 152; 1993, s. 355-357; 2013, s. 75-76 i ryc. 41, tam zaznaczono okaz ze Stroszek) grzebienie wyżej wymienionych typów produkowali wyspecjalizowani grzebiennicy skandynawscy, zwłaszcza związani z polietnicznymi osiedlami wczesnomiejskimi w Hedeby na terenie Starej Danii oraz w Birce na terytorium Swewów. Część tego typu grzebieni mogli wykonać również rzemieślnicy wędrowni (na ten temat zob. np. K. Ambrosiani 1981, s. 40 i n.; patrz też przypis $5 \mathrm{w}$ niniejszym artykule). Dodajmy, że sformułowana przez wymienioną badaczkę hipoteza, jakoby wyróżnione przez nią grzebienie grupy B1-B4 (o ich związku z grzebieniem ze Stroszek zob. wyżej) wywodziły się z zachodniosłowiańskich ośrodków rzemieślniczo-handlowych, ulokowanych na południowym wybrzeżu Morza Bałtyckiego, jest w aktualnym stanie badań co najmniej dyskusyjna (K. Ambrosiani 1981, s. 32-40, 62-66, rys. 11:2; 33) ${ }^{16}$.

${ }^{16}$ Najprawdopodobniej za pośrednictwem wspomnianych ośrodków wczesnomiejskich lub rzemieślniczo-handlowych - zlokalizowanych m.in. w rejonie ujścia Odry (Menzlin, Wolin, być może też Szczecin), tudzież powiązanych z nimi funkcjonalnie sezonowych miejsc obrzędowo-targowych, położonych w dorzeczu dolnej Obry (np. Pszczew, stan. 2, woj. lubuskie), jak też w rejonie ujścia Noteci do Warty (np. Santok, stan. 1, woj. lubuskie) - do rzemieślniczo-handlowych ośrodków na terenie Skandynawii trafiało natomiast poszukiwane przez tamtejszych grzebienników poroże jelenia szlachetnego (Cervus elaphus L.), gatunku żyjącego w tym czasie na obszarze Europy Środkowej oraz w północnej i wschodniej części Półwyspu Skandynawskiego (zob. van Riel 2017, s. 166, ryc. 3). $\mathrm{Z}$ tego rodzaju surowca wykonany został również grzebień znaleziony w Stroszkach. Tytułem przykładu odnotujmy, iż wśród analizowanych fragmentów poroża jelenia, odkrytych w reliktach emporium w Hedeby, aż 87\% okazów pochodziło prawdopodobnie z importu. Wykazały to badania laboratoryjne zawartości stabilnych izotopów strontu $\left({ }^{87} \mathrm{Sr} r{ }^{86} \mathrm{Sr}\right) \mathrm{w}$ próbkach poroża. Wskazuje się na istotną rolę dalekosiężnej, etapowej wymiany handlowej, ukierunkowanej na osi Północ-Południe. W tym przypadku badacze podkreślają wyjątkowe znaczenie kontaktów Hedeby z krajami Półwyspu Skandynawskiego, pomijając - naszym zdaniem niesłusznie - związki tegoż ośrodka w interesującej nas dziedzinie handlu ze Słowiańszczyzną nadbałtycką (zob. van Riel 2017, s. 174-175, tamże dalsza literatura).

Wspomniane relacje dobrze ilustrują znaleziska $\mathrm{z}$ wielofazowego osiedla targowego w Santoku (stan. 1), z czasem przekształconego w obwarowane, wielofunkcyjne miejsce centralne. Począwszy od I poziomu użytkowego tegoż osiedla, datowanego na koniec VIII i początek IX w. (datowanie poziomów według Kara 2006a, s. 232, 234, ryc. 10-11) stwierdzono tam fragmenty wstępnie obrobionego poroża jelenia, jak również liczne i ,proste” w formie przedmioty (tzw. kolce, igły, szydła, oprawki rękojeści) wykonane z poroża, zapewne na miejscu, wśród których obecne są też półfabrykaty (Podgórski 1966; Dymaczewska i Dymaczewski 1967, s. 191 i n., s. 232/233, tabela). W Santoku odnotowano także liczne ekskluzywne grzebienie sporządzone z poroża jelenia (Zamelska-Monczak 2014), w zdecydowanej większości ornamentowane, ujawniajace analogie wśród datowanych na IX-X w. znalezisk z Anglii, Fryzji i północnych ziem Dolnej Saksonii, przy czym szczególnie bliskie pochodzą z Jutlandii, m.in. z Hedeby (por. Jankuhn 1943, s. 148 i n.; Roes 1963, tabl. 14 i n.; Tempel 1970; 1979; Ulbricht 1978, tabl. 29-33; MacGregor 1985, s. 88 i n.; MacGregor, Mainman i Rogers 1999, 
Do poglądów K. Ambrosiani nawiązują ustalenia M. Brzostowicza (1996, s. 272), dotyczące miejsca produkcji grzebienia ze Stroszek. Badacz dopuścił, aczkolwiek uczynił to ostrożnie, zachodniopomorską proweniencję analizowanego za-

s. 1923 i n.). Są to ewidentne ,importy” (w Santoku stwierdzono jedynie ślady sugerujące naprawy grzebieni), które do wymienionego ośrodka trafiły zapewne w wyniku dokonywanej tam sezonowej wymiany handlowej. Najprawdopodobniej stanowiły one jeden z ekwiwalentów przekazywanych członkom lokalnej wspólnoty, w zamian za wstępnie obrobione poroże jeleni i łosi, za zboże (vide znaleziska bardzo licznych ziarniaków zbóż, notowane już od I poziomu osadniczego), za wełnianą przędzę (vide liczne znaleziska przęślików, rejestrowane również począwszy od najstarszego poziomu osadniczego Santoka oraz bardzo liczny udział w tamtejszym materiale osteologicznym kości owiec/ kóz), a także za produkty gospodarki leśnej, zwłaszcza miód, wosk, sadło bobrów (?) oraz skóry szlachetnych zwierząt futerkowych, takich jak borsuk, kuna, lis, wydra czy bóbr, których kości wyraźnie poświadczone są w znaleziskach santockich (zob. Dymaczewska i Dymaczewski 1967, s. 191 i n.; Hensel i Hilczer-Kurnatowska 1987, s. 16-17, tab. 2-3). W krąg luksusowych ekwiwalentów wymiany, jakie trafiały do Santoka, włączyć należy również tkaniny wełniane, m.in. pochodzące (podobnie jak grzebienie) z Jutlandii i/lub Fryzji, które odkryto już w najstarszym poziomie użytkowym Santoka, skórzane obuwie, osełki zapewne z norweskiego fyllitu, biżuterię, elementy stroju oraz niemonetarne formy pieniądza w postaci bryłek bursztynu i paciorków, w tym szklanych ze złotą folią (znaleziska paciorków począwszy od najstarszych poziomów osiedla) (zob. Niesiołowska-Wędzka 1965; Dymaczewska, i Dymaczewski 1967, s. 191 i n., s. 232-233, tabela; Hensel i Hilczer-Kurnatowska 1987, s. 16-17, tab. 2; Kara 2006b, s. 402-403; Lisowska i in. 2017). Wśród wymienionych artefaktów (zwłaszcza elementów stroju) należy spodziewać się też okazów stanowiących osobista własność przybyszów, z tego powodu wyłączonych zasadniczo z wymiany, które uległy zagubieniu bądź zostały wyrzucone jako destrukty. Mogą być to zatem „importy” pozorne.

Opisany zbiór luksusowych przedmiotów, przeważnie o wyraźnych analogiach w kulturze skandynawskiej starszego i środkowego okresu wikińskiego, pozostaje bez odpowiednika $\mathrm{w}$ interiorze ziem polskich. Ujawnia natomiast bliskie relacje - w zakresie liczebności, jak też składu oraz charakteru zbioru - z kulturą rzemieślniczo-handlowych osiedli IX-X stulecia, położonych w zachodniosłowiańskiej strefie nadbałtyckiej. Należy domyślać się, iż właśnie z tych ośrodków pochodzili odwiedzający sezonowy targ w Santoku nabywcy wyżej wymienionych towarów oraz dóbr naturalnych (poza Słowianami nie wykluczamy wśród nich Normanów, a nawet Fryzów). W okresie od końca VIII do 2. połowy IX w. szczególnie istotne wydają się relacje Santoka z Menzlinem i Hedeby (?), zastąpione pod koniec IX-X stuleciu głównie przez kontakty z Wolinem (tudzież z Hedeby?), przy czym w obu przypadkach nie można wykluczyć pośrednictwa wczesnomiejskiego ośrodka w Szczecinie (na ten temat Kara 2015). O kontaktach $\mathrm{z}$ Wolinem świadczą m.in. stwierdzone w VI poziomie użytkowym santockiego osiedla, datowanym na 2. połowę X w., znaleziska typowych dla rogownictwa wolińskiego ekskluzywnych grzebieni typu IB-VII-5b według Cnotliwego (1973; patrz też Łosiński 2008, s. 40; Zamelska-Monczak 2014, s. 55). Istotną rolę w tych relacjach odgrywało położenie Santoka w lokalnej sieci rzek, zapewniające mu sprawną komunikację m.in. z rejonem ujścia Odry. Na koniec odnotujmy, że rozpoznane w Santoku zjawiska w zakresie chronologicznym i przyczynowo-skutkowym wpisują się wyraźnie w okresy szczególnej aktywności gospodarczej społeczności ziem basenu Morza Bałtyckiego, które archeologia synchronizuje z falami napływu na wyżej wymienione terytorium srebrnych dirhemów arabskich (najstarszy strumień tegoż srebra datowany jest na koniec VIII w. - por. Łosiński 1988; 1993; 2008, s. 39). Dodajmy, iż osiedla targowe typu Santok, położone w interiorze ziem Połabia Północnego tudzież na pograniczu obecnej Wielkopolski i Pomorza, nie uległy przekształceniu w znane ze strefy nadbałtyckiej ośrodki rzemieślniczo-handlowe (Seehandelsplätze) typu Menzlin-Ralswiek, mimo iż podobnie jak one włączone były w struktury szerszego układu gospodarczego (por. Łosiński 2008, s. 13-60, 125-169). W przeciwieństwie do wspomnianych ośrodków, służyły jedynie aprowizacji tychże osiedli w żywność oraz niezbędne dla rzemiosła surowce strategiczne, co odbywało się jednak bez udziału ekwiwalentu monetarnego (do XI w. w Santoku brak pewnie potwierdzonych znalezisk wag, odważników i monet - zob. Hensel i Hilczer-Kurnatowska 1987, s. 16-17, tab. 2; Kara 2015). Z kolei elitom interioru targowe osiedla typu Santok zapewniały dostęp do ekskluzywnych towarów. 
bytku, upatrując w znalezisku wyrobu pracowni rogowniczej z Kołobrzegu (?) lub Wolina (?). Do tej listy dopisać można też miejscowość Janów Pomorski (obecnie Janów, woj. warmińsko-mazurskie) nad jeziorem Drużno, gdzie w pozostałościach odkrytej przez archeologów osady rzemieślniczo-handlowej z VII/VIII-X w., przekonująco interpretowanych jako relikty Truso - emporium położonego na pograniczu ziem pruskich i zachodniosłowiańskich - również stwierdzone zostały ślady intensywnej obróbki poroża i kości (Jagodziński 2010, s. 175 i n.; Brather 2010; Cnotliwy 2013). Wszystkie z wymienionych ośrodków ujawniły znaleziska, które bez zastrzeżeń łączyć można $\mathrm{z}$ mniej lub bardziej zaawansowaną produkcją grzebienniczą. W żadnym z ośrodków nie odnotowano jednak ewidentnych dowodów na wytwórczość grzebieni typu IB-VIII-1a oraz ,pokrewnych” im okazów typu IB-VIII-2 według E. Cnotliwego (1973), w obu przypadkach bardzo podobnych do grzebienia ze Stroszek. Dodajmy, że znalezione w dorzeczu Odry i Wisły grzebienie typu IB-VIII-1 lub IB-VIII-2 są nieliczne (ryc. 4). Stwierdzone zostały w obrębie polietnicznych osiedli, najprawdopodobniej zamieszkanych m.in. przez grupy Skandynawów (Wolin, Kamień Pomorski?, Kołobrzeg?), lub - jak emporium w Truso - może niemal wyłącznie przez ludność normańską (?). Znamienne, iż niektóre z odkrytych w Polsce grzebieni typu IB-VIII-1/2 to według ustaleń archeologów ,importy” z Hedeby lub Birki (Cnotliwy 1973, s. 148-154; 2013, s. 75-76).

Za ,import” z Birki uznano m.in. grzebień typu IB-VIII-1a, który znaleziony został w reliktach drugiego poziomu zabudowy wczesnomiejskiego osiedla w Kołobrzegu (obecnie Budzistowo, woj. zachodniopomorskie), datowanych na 1. połowę, zapewne 1. ćwierć X w. (Tabaczyńska 1959, s. 74, 87-89, tabl. II:2; Żak 1963, s. 64 , nr 83 , ryc. 65 ; Leciejewicz 2007 , s. $45-50$, ryc. $37: 4$ ). Dla naszych rozważań jest to znalezisko istotne, zważywszy na odnotowany powyżej domysł M. Brzostowicza, sugerujący związek grzebienia ze Stroszek (przypomnijmy, również okazu typu IB-VIII-1a, nadto o podobnej metryce) ze stwierdzoną w Kołobrzegu wytwórczością grzebienniczą.

Interesujący nas grzebień „kołobrzeski” odkryty został w pobliżu pozostałości pracowni rogowniczo-bursztyniarskiej, w obrębie której, jak też w jej najbliższym otoczeniu, stwierdzono ślady produkcji grzebienniczej. Mimo to w literaturze zgodnie przyjmuje się obce pochodzenie rzeczonego grzebienia, wskazując na jednostkowy w przypadku Kołobrzegu charakter znaleziska (Tabaczyńska 1959, s. 87-89; Żak 1967, s. 310-311; Cnotliwy 1973, s. 151; Leciejewicz 2007, s. 50). Wyklucza się nawet związek omawianego grzebienia z reliktami wspomnianej pracowni rogowniczej. Grzebień zalegał bowiem w dolnej partii warstwy nr VII, która w eksplorowanym wykopie badawczym (nr I/1954-1956) wyznaczała drugi poziom zabudowy osiedla. Został znaleziony poza zasięgiem odpadów produkcyjnych łączonych z działalnością pracowni. Leżał natomiast obok kołka, wzmacniającego konstrukcję jej plecionkowych ścian, przy czym według odkrywców kołek ów uszkodził płytki zębate grzebienia (Tabaczyńska 1959, s. 71-77, 87; Żak 1963, s. 64, nr 83; Cnotliwy 1973, s. 62-63). Grzebień mógł zatem trafić do ziemi, zanim 


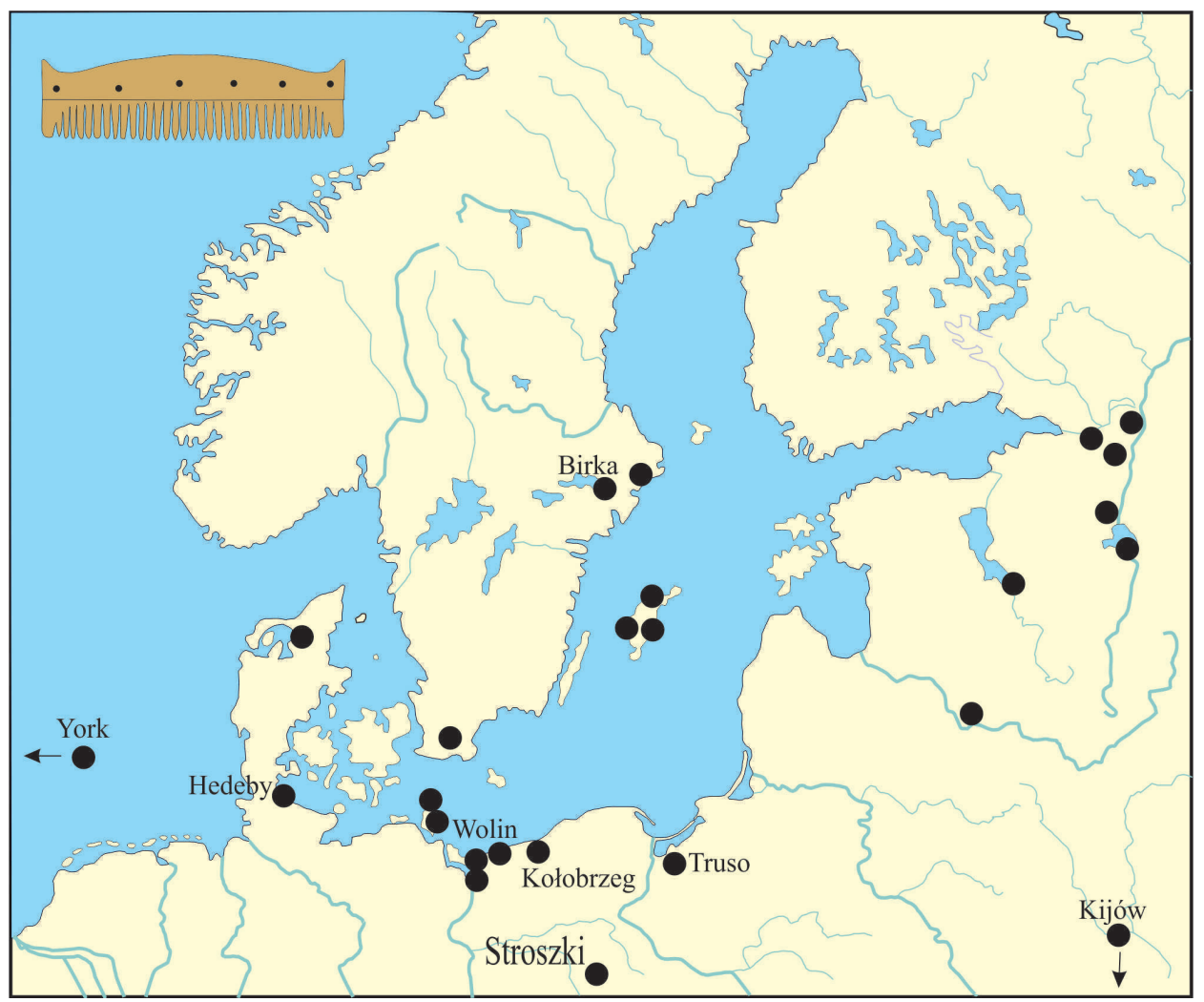

Ryc. 4. Mapa z lokalizacją w strefie nadbałtyckiej znalezisk wczesnośredniowiecznych grzebieni typu IB-VIII-1/2 według E. Cnotliwego (1973), zasadniczo tożsamych z typem „Birka” według tegoż badacza (1993). Według: Cnotliwy 1973, ryc. 63; 1993, ryc. 16; 2013, ryc. 41;

z modyfikacją M. Kara. Przerys. J. Sawicka

wzniesiono w tym miejscu budynek pracowni. Dodajmy, że grzebienie uznane przez badaczy za ewentualne produkty wytwórców ośrodka kołobrzeskiego to okazy spojone nitami brązowymi. Natomiast odkryty w rejonie pracowni grzebień typu IB-VIII-1a zespolony został za pomocą nitów żelaznych (zob. Cnotliwy 1973, s. $56-57,88-89,150)$.

W tej sytuacji bardziej uzasadnione wydaje się łączenie grzebienia ze Stroszek z wytwórczością rzemiosła skandynawskiego ze środkowego okresu wikińskiego (koniec IX-2. połowa X w.), mimo iż wśród znanych nam artefaktów kultury normańskiej brakuje doń ścisłych analogii. Za proponowaną ewentualnością przemawia jednak ogólna forma wspomnianego grzebienia, wnosząc z liczebności oraz chorologii znalezisk, bardzo popularna wśród Skandynawów przełomu starszych 
i młodszych faz wczesnego średniowiecza, jak również technika wykonania tegoż przedmiotu, zwłaszcza sposób jego nitowania oraz rodzaj użytych nitów.

Stwierdzona w przypadku grzebienia ze Stroszek technika every edge (,na każdej krawędzi/na każdym styku płytki zębatej”) oraz zbliżona do niej technika alternating edge („,na krawędzi co drugiej płytki zębatej”) były w okresie wikińskim powszechnie stosowane $\mathrm{w}$ grzebiennictwie skandynawskim, aczkolwiek na zasadzie terytorialnej rozdzielności. I tak pierwszą z technik posługiwano się zwłaszcza w Norwegii oraz środkowej Szwecji (Birka), także na Orkadach, rzadziej w emporiach skandynawskich na obszarze Anglii, natomiast technika alternating edge stosowana była głównie w Anglii oraz na terenie południowo-zachodniej Skandynawii, przede wszystkim w Hedeby (Ashby 2009, s. 16-17; 2013, s. 201). W obu przypadkach używano niewielkich nitów wykonanych z żelaza lub stopów miedzi, sporadycznie z materiałów organicznych: z poroża (?) bądź kości. Technikę every edge, z zastosowaniem nitów żelaznych, ujawniły też odkryte na ziemiach polskich grzebienie typu IB-VIII-1a (Cnotliwy 1973, s. 150), w tym okaz ze Stroszek. Ponadto stwierdzono ją w ośrodku wolińskim, gdzie zdecydowana większość odkrytych tam trójwarstwowych grzebieni jednorzędowych, w przeciwieństwie do tego rodzaju okazów znalezionych w Kołobrzegu i Gdańsku, została zespolona za pomocą nitów żelaznych (Cnotliwy 1973, s. 56-57, 88-89).

Także motywy zdobnicze, pokrywające grzebień ze Stroszek, odnotować można w kulturze Skandynawów wczesnego średniowiecza. W tym kręgu kulturowym popularny był również zwyczaj nanoszenia tego samego lub podobnego ornamentu na płaszczyzny obu okładzin bocznych trójwarstwowych grzebieni jednorzędowych, powszechnie praktykowany też $\mathrm{w}$ grzebiennictwie zachodniosłowiańskim wczesnego średniowiecza, rzadki natomiast $\mathrm{w}$ grzebiennictwie fryzyjskim tego czasu (Tempel 1979, s. 171).

Wizerunek ryby - bardzo podobny do wyobrażonego na grzebieniu ze Stroszek - widnieje przykładowo na nordyjskich półbrakteatach typu Hedeby (KG 3), emitowanych w 1. połowie IX w. (wzorowane na monetach wczesnokarolińskich), które w obiegu pozostawały też w następnym stuleciu (zob. Malmer 1966, s. 341, tabl. 1:4-7; 33:3-4; 2002, s. 120-122, ryc. 1:8). Tego rodzaju wizerunki dostrzegamy również na dwu płaskorzeźbionych kamieniach, przedstawiających spektakularne - według skandynawskiej mitologii epoki wikingów - czyny wojowniczego boga Thora z rodu Asów, w których zmaga się on z naporem złych istot, niosących zagładę światu (zob. Lindqvist 1941, tabl. 59-60; 1942, s. 24, nr 17, 19, ryc. 311; Lang 1984, s. 129-130, ryc. 4; Ellmers 1986, s. 363-364, ryc. 18; 1998, s. 483-494; Wamers 1997, s. 107, tabl. 2:3a-3b; Marold 1998, s. 39-47; Słupecki 2003, s. 157; 
Simek 2003, s. 134; Oehrl 2012, s. 284-287, ryc. 6). W ten sposób Thor usiłuje przywrócić pierwotną harmonię Kosmosu ${ }^{17}$.

Pierwszy z wyżej wymienionych zabytków to obrazkowy kamień nr VIII z m. Ardre na Gotlandii (Szwecja), wykonany w X stuleciu ${ }^{18}$ (ryc. 5); drugi to monumentalny X-wieczny tzw. kamień-krzyż Thorwalda z Kirk Andreas na Wyspie Man (Wielka Brytania). Przedstawiono na nich (w przypadku kamienia-krzyża Thorwalda $\mathrm{w}$ formie zsyntetyzowanej i w sposób symboliczny) walkę Thora $\mathrm{z}$ morskim potworem - Wężem Midgardu (Midgardsormem), potężnym wrogiem Asów, a zarazem jednym z głównych uczestników ostatniej bitwy nordyjskich bogów z mocami zła, poprzedzającej Ragnarök (zob. Edda poetycka, „Hymiskvida” 16-25, s. 103-104). Na kamieniu z Ardre zilustrowano też schwytanie przez Thora ojca Midgardsorma - Lokiego, kluczowego uczestnika wspomnianej bitwy, jako przywódcy złych mocy, który w czasach poprzedzających Ragnarök ukrył się przed zemstą Asów w wodospadzie Franangr, gdzie przybrał postać łososia (zob. „Lokasenna”, epilog, s. 124; Snorri Sturluson, Edda, „Gylfaginning” 50, s. 51-52).

Wizerunki ryb, potraktowane jednak bardziej schematycznie, widnieją też na płaskorzeźbionym kamieniu (fragmencie chrześcijańskiego krzyża lub grobowca) z m. Gosforth (Cumberland) w Anglii (ryc. 6), datowanym około roku 900, w scenie opisującej wspomniany pojedynek Thora z Wężem Midgardu (Shetelig 1933, s. 222-224; Wamers 1997 , s. 98-99, ryc. 10:1; Ellmers 1998, s. 489, ryc. 4:1; Słupecki 2003, s. 157). Na koniec odnotujmy osełkę (kamień probierczy?, amulet?) w kształcie ryby znalezioną w $\mathrm{m}$. Ketting w Danii, w pochodzącym z X stulecia grobie konnego wojownika (Brøndsted 1936, s. 130-131, 138, ryc. 38; Pedersen 2014 [Catalogue], s. 100, nr 347, grave II; 2014 [Text], s. 177, tab. 6.2, nr 347, s. 218).

Powyższe zabytki to okazy związane $\mathrm{z}$ elitarnym nurtem kultury normańskiej okresu wikińskiego ewidentnie inspirowanej żywiołem wodnym. Obecne wśród nich źródła ikonograficzne zawierają m.in. sceny ilustrujące bohaterskie czyny boga Thora, jakich dokonał on w wodach wodospadu Franangr bądź w kryjących Midgardsorma wodach „światowego morza”, które opływając Midgard, czyli zaludnioną ziemię, oraz Jötunheim, czyli mroźną północną siedzibę olbrzymów, wyznaczało granice boskiego i ludzkiego poznania. Dodajmy, iż według mitologii

\footnotetext{
${ }^{17}$ Skandynawski, gromowładny bóg Thor przypomina w swych bohaterskich działaniach herosów - niezwykle walecznych wojowników pochodzenia boskiego, będących niejednokrotnie hipostazą gromowładcy, których znamy z mitologii innych ludów indoeuropejskich. Tytułem przykładu odnotujmy greckiego Heraklesa, syna gromowładnego Zeusa, oraz jego 12 heroicznych prac (por. Kubiak 1997; Kempiński 2001). Na ten temat patrz też Libera 1987, s. 129, 132; Słupecki 2003, s. 129 i n.: „Podobieństwo obu tych postaci [Thora i Herkulesa - dop. M.K.], a do nich należy jeszcze dodać wedyjskiego Indrę [...], tkwi przede wszystkim w ich charakterze, miejscu, jakie zajmują w świecie bogów i w naturze przypisywanych im czynów, czyli w podobieństwie funkcji, jaką spełniają w swoich mitologiach" (s. 130).

${ }^{18}$ Na wiek X kamień datuje m.in. S. Oehrl (2012, s. 284-285, tamże dalsza literatura). W starszych opracowaniach synchronizowany jest z końcem VIII w. (np. Lindqvist 1941; 1942).
} 


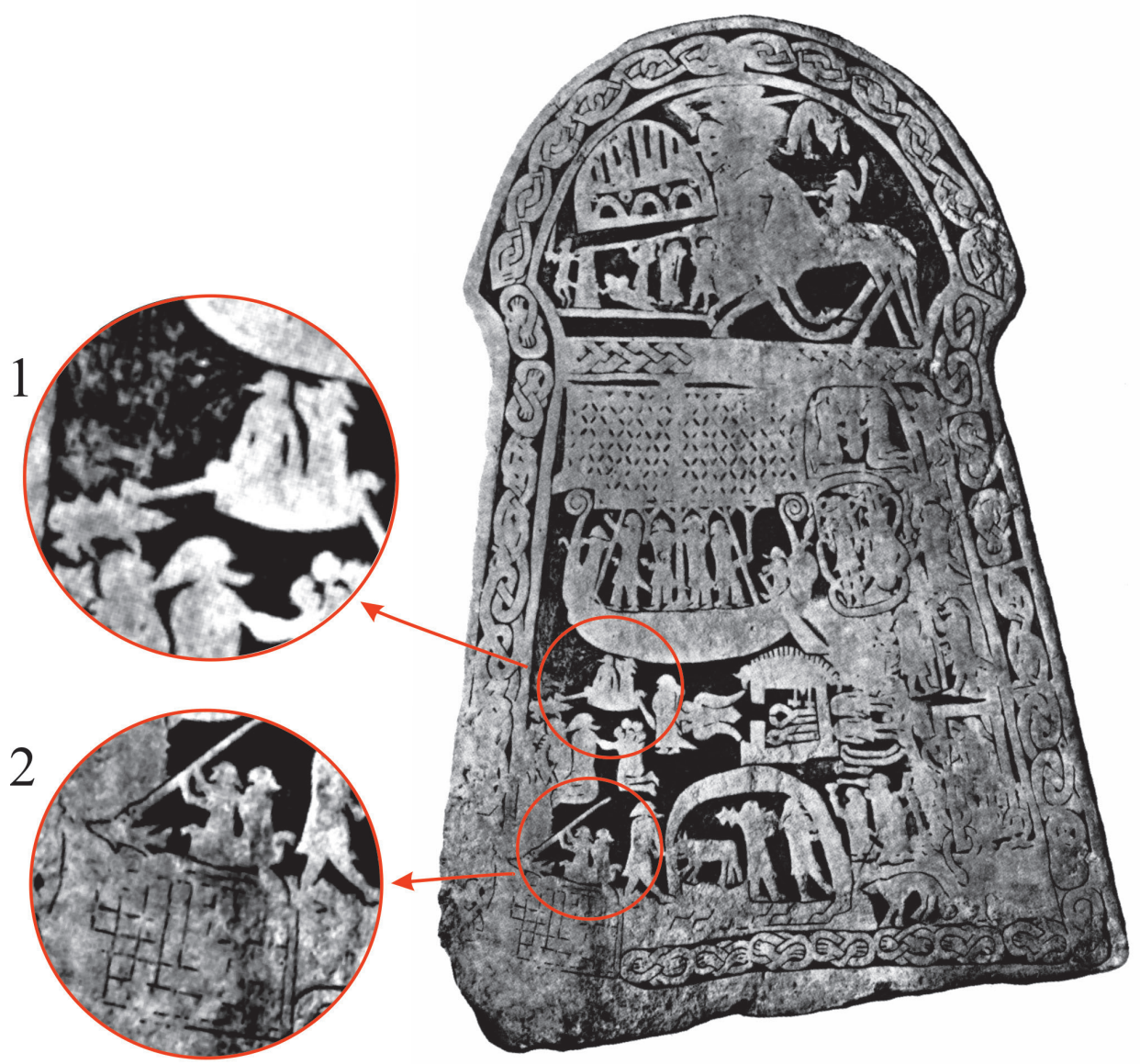

Ryc. 5. Tzw. obrazkowy kamień nr VIII z Ardre na Gotlandii (Szwecja) z X w., przedstawiający m.in. scenę połowu wielorybów przez boga Thora i olbrzyma Hymira, poprzedzającego pojedynek Thora $\mathrm{z}$ jadowitym wężem Midgardsormem (1), oraz scenę połowu siecią olbrzyma Lokiego, ukrytego pod postacią łososia w wodospadzie Franangr, przez bogów z rodu Asów, z walnym udziałem Thora (2). Opracowanie M. Kara na podstawie: Lindqvist 1941, ryc. 139; Oehrl 2012, ryc. 6; z modyfikacją. Opracowanie komputerowe J. Sawicka

skandynawskiej Midgardsorm opasywał swym cielskiem ziemię, chroniąc $\mathrm{w}$ ten sposób Midgard przed rozsunięciem, a więc zniszczeniem, które nastąpi w dniu Ragnarök ${ }^{19}$. Wspomniane przedstawienia dowodzą, iż motyw ryby, także w wersji

19 Zob. Kempiński 2003, s. 150-151, 172-173; Słupecki 2003, s. 48, 50, 57 i n. Przekonanie o istnieniu prakosmicznego morza „skuwającego" Świat, w związku z czym tworzył on jedność, było zjawiskiem ponadczasowym i ponadregionalnym. Tytułem przykładu odnotujmy obecność tego rodza- 
Ryc. 6. Płaskorzeźbiony kamień z około 900 r. (fragment chrześcijańskiego krzyża lub grobowca) z Gosforth (Cumberland) w Anglii, ze sceną połowu wielorybów przez boga Thora i olbrzyma Hymira, poprzedzającego pojedynek Thora $\mathrm{z}$ jadowitym wężem

Midgardsormem. Według Shetelig 1933, ryc. 82

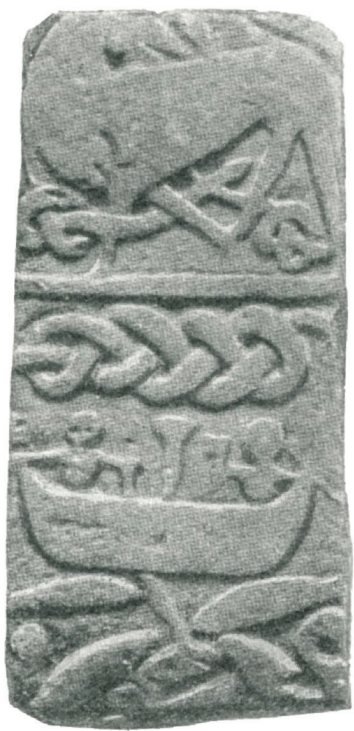

realistycznej, znany był nordyjskim twórcom doby wikińskiej, aczkolwiek w przeciwieństwie do wizerunków ptaków, węży czy stylizowanych zwierząt lądowych (por. Wilson i Klindt-Jensen 1980), nie był stosowany zbyt często. W tym miejscu warto odnotować koncepcję duńskiego archeologa B. Jensena (2013), który obecną w kulturze skandynawskiej okresu wikińskiego symbolikę zwierzęcą łączy z wnikliwą obserwacją przyrody przez ówczesne społeczności. Według Jensena wspomniana symbolika odzwierciedlać ma rzeczywisty podział na zwierzęta przyjazne człowiekowi oraz zagrażające jego egzystencji.

W tej sytuacji, zważywszy na silne relacje kulturowe i gospodarcze Normanów z wodami rzek, jezior czy mórz (zob. Leciejewicz 1979; Ellmers 1986; 1998; Roesdahl 1991), zastanawiać może niewielka frekwencja wizerunków ryb odnotowana w skandynawskich źródłach archeologicznych doby wikińskiej. Niewykluczone, że przyczyn tego zjawiska należy upatrywać w semantycznym kodzie, jaki morskiej oraz słodkowodnej rybie przypisywały we wczesnym średniowieczu ludy Europy Północnej. W panteonie ich symbolicznych wyobrażeń mógł to być znak szczególny, sprzyjający z kolei praktykom magicznym z udziałem wizerunków ryb oraz rybich kości. W odniesieniu do Skandynawów okresu wikińskiego, za tak sformułowaną hipotezą przemawiają potwierdzone źródłowo przypadki rycia magicznych run na amuletach $\mathrm{z}$ wizerunkiem ryby (np. pochodzący z XI w. okaz z m. Södra Kvinneby na Olandii-Szwecja; Jansson 1957 - zob. ryc. 7), na amuletach w kształcie ryby (np. znalezisko z Grenlandii; Nørlund 1937, s. 32 - zob.

ju wyobrażenia w dawnych wierzeniach ludów bałtyckich (zob. Suchocki 1987, s. 139 i n., zwłaszcza s. 157-158), które utrzymywały relacje kulturowe m.in. ze Skandynawami. 


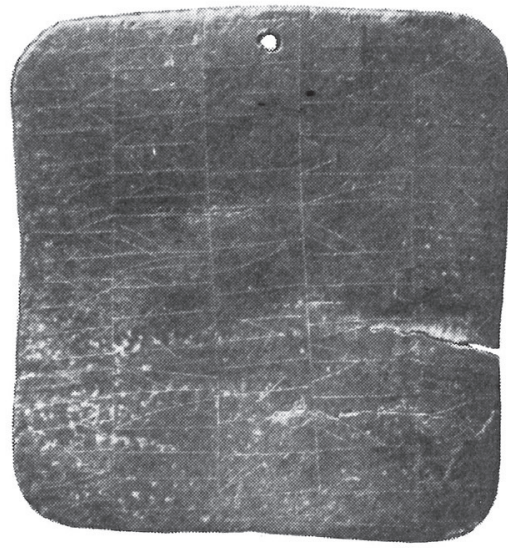

1

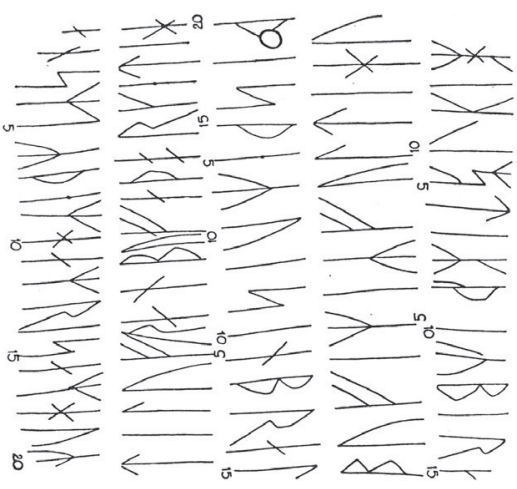

3

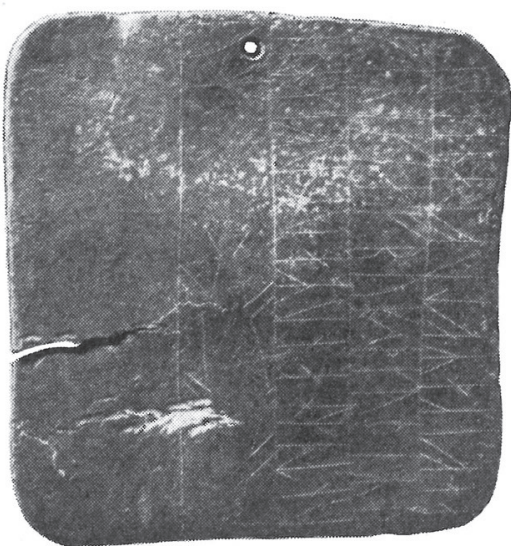

2

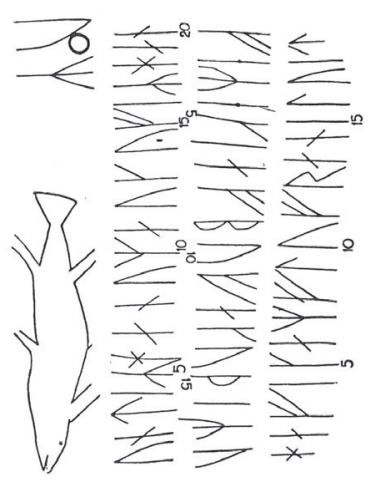

4

Ryc. 7. Fotografia wczesnośredniowiecznego amuletu w kształcie miedzianej blaszki (1-2), znalezionego w m. Södra Kvinneby na Olandii (Szwecja), wraz z przerysem napisu runicznego oraz wizerunku ryby pokrywających przedmiot (3-4). Według Jansson 1957, ryc. 1-4

ryc. 8) lub na rybich oskrzelach (vide staroislandzka Saga o Egilu, s. 174-175, $181-182)^{20}$.

${ }^{20}$ Wisiorek z kości (tarczy) jesiotra, będący zapewne amuletem, co sugerują wyryte na jednej z jego szerszych płaszczyzn znaki przypominające runy (w literaturze sugeruje się niesłusznie litery łacińskie), odkryto też w Gdańsku na Pomorzu Nadwiślańskim, w reliktach ewidentnie słowiańskiego grodu z przełomu XI i XII w. (Gdańsk, stan. 1 [Zamczysko, ul. Rycerska 4/5], warstwa 15). Zob. Jażdżewski, Kamińska i Gupieńcowa 1966, tabl. XVII:15 (nr 54/6474); Zbierski 1985, s. 256 oraz 


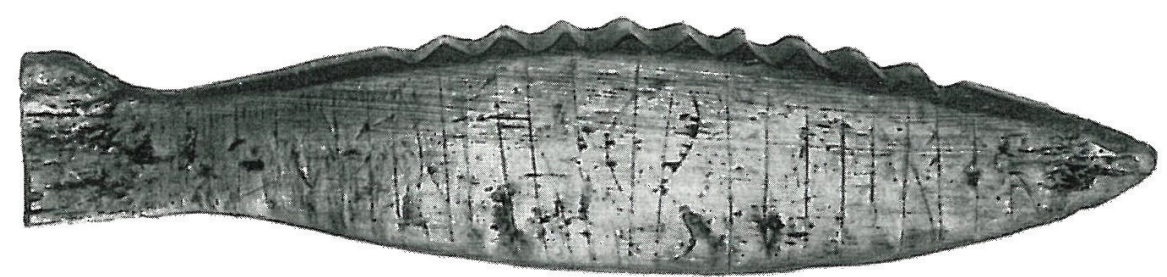

Ryc. 8. Przedmiot (zapewne amulet) w kształcie ryby z napisem runicznym, znaleziony na Grenlandii. Według Nørlund 1937, ryc. 24

Przedmiotem, który w kulturze Skandynawów wczesnego średniowiecza również traktowano w sposób szczególny, była rybacka sieć. Mitologia normańska domyślnie przypisuje ów wynalazek siłom nadprzyrodzonym, upatrując w olbrzymce Ran - władczyni morza - właścicielki misternie splecionej sieci (net), którą łowiła topielców, w związku z czym kojarzona była przez ludzi, zwłaszcza przez żeglarzy, ze światem pozagrobowym (Kempiński 2003, s. 174; Słupecki 2003, s. 297, 325; Simek 2003, s. 211-212). W tym przypadku warto zwrócić uwagę na podobnie ujętą genezę północnogermańskich run, których prymarną znajomość wspomniana mitologia przypisuje najwyższemu z nordyjskich bogów - Odinowi/ Odynowi (Edda poetycka, „Hávamál” V.138, 141, 142, s. 46-47; patrz też Kempiński 2003, s. 177-181). Rybackie właściwości sieci bogini Ran ujawniły się w zmaganiach Lokiego z karłem Andwarim. Wówczas to za pomocą wspomnianej sieci pochwycony został żywcem przemieniony w rybę Andwari, który pod postacią szczupaka strzegł złotego skarbu ukrytego w pełnym ryb wodospadzie Andwarafors (zob. Edda poetycka, „Reginsmál”, prolog, s. 251-252). Z kolei magiczne właściwości sieci, wyplecionej przez Lokiego na wzór używanej przez Ran, uwidoczniły się podczas ucieczki wspomnianego olbrzyma przed pałającymi zemstą Asami. Nieustannie wyplatając z lnianej przędzy sieć rybacką, Loki próbował zakląć w jej węzłach Los/Przeznaczenie, aby w ten sposób uniemożliwić odszukanie jego kryjówki, o czym w nieco zawoalowanej formie poinformował autor Eddy (Młodszej/Prozaicznej) - Snorri Sturluson („Gylfaginning” 50, s. 51-52). Podkreślmy, że w tym przypadku poglądy północnych Germanów wpisują się w szerszy nurt przekonań ludów tzw. tradycyjnych, w których sieć, dzięki splotom i wiązaniom, łączona jest zwykle z symboliką spowijania, pętania i pochłaniania (Cirlot

fot. amuletu na wkładce po s. 240; Makowiecki 2003, fot. 6; Kościński i Paner 2005, s. 10, tabela 1, tam zweryfikowane datowanie warstw kulturowych z wyżej wymienionego stanowiska. 
2007, s. 368; zob. też Lurker 1989, s. 211-212; Kopaliński 1990, s. 374-375; Oesterreicher-Mollwo [red.] 1992, s. 143; Kempiński 2001, s. 454 [hasło: Waru$n a])$. W tym charakterze sieć służyła $\mathrm{w}$ starożytności i średniowieczu jako narzędzie przydatne w połowach ryb i polowaniach. Ze względu na konotacje sakralne (vide Waruna, Marduk, Ea, Jahwe) sieć lub jej specyficzną odmianę - arkan, uznawano za elitarną formę broni, która pozwalała łowić lub krępować ludzi i zwierzęta, stanowiąc jednocześnie znak władzy nadprzyrodzonej, suwerennej i nieograniczonej. W związku $\mathrm{z}$ tym $\mathrm{w}$ wymiarze symbolicznym sieć postrzegano m.in. jako niewód, pochłaniający zło lub złe uczynki oczekujące sprawiedliwego sądu (zob. Biblia Tysiaclecia, „Księga Ezechiela” 17.20, s. 999). Dopiero chrześcijaństwo, począwszy od stadiów najstarszych, nadało sieci rybackiej jednoznacznie pozytywny sens symboliczny, traktując jako narzędzie działania zbawczego, przy czym w nawiązaniu do tradycji ludów nadśródziemnomorskich sięgnięto po topos udanego (szczęśliwego) połowu ryb, w tym przypadku dokonywany przez św. Piotra. W związku z tym od końca II w. sakrament chrztu zaczęto przyrównywać do połowu ryb, a wypełnioną rybami sieć traktować z czasem jako symbol Kościoła (Lurker 1989, s. 211-212).

O symbolicznej (w tym magicznej lub quasi-magicznej) atrybucji wizerunków ryb oraz rybackich sieci decydował najprawdopodobniej kojarzony z nimi różnorodny żywioł wodny (naturalne środowisko ryb), który w „tradycyjnej” kulturze ludów nie tylko indoeuropejskich uznawany jest za element świata chtonicznego - żywiołu mrocznego i przewrotnego w reakcjach (por. P. Kowalski 1998, s. 609-615; Kempiński 2001, s. 467-468). W nawiązaniu do ostatniej uwagi odnotujmy ślady tego rodzaju przekonań w pierwotnej tradycji Kościoła, który nakazywał chrzcić jedynie wodą źródlaną, czyli „wodą żywą”, wyłączając jednocześnie z sakramentalnego obrzędu chrztu wodę morską, traktowaną jako „wodę śmierci”, w nawiązaniu do wód Morza Czerwonego, jakie pochłonęły faraona oraz jego wojska podczas ucieczki Izraelitów z Egiptu (Ratzinger b.r.w., s. 196). W starożytności i wczesnym średniowieczu tryskająca z podziemi woda, skumulowana w zbiornikach oraz korytach rzek, wywoływała bowiem, podobnie jak sfera chtoniczna, $\mathrm{z}$ jednej strony zainteresowanie i szacunek, $\mathrm{z}$ drugiej zaś poczucie uzasadnionego niepokoju, ze względu na ambiwalentny charakter tkwiących w niej mocy. Woda była bowiem groźna w kontaktach fizycznych, gdy pochłaniała łodzie i/lub życie ludzkie, dla człowieka była w zasadzie niedostępna ze względu na brak powietrza, a jednocześnie posiadała walory oczyszczające. Pełna była również mrocznych, a przez to tajemniczych mocy witalnych, niezbędnych do życia, a zarazem potrafiących unicestwić inny potężny tudzież tajemniczy według ówczesnych przekonań żywioł kosmiczny, jakim był ogień. Według wczesnośredniowiecznych Skandynawów w wodzie, analogicznie jak w runach, miała zatem tkwić przewrotna siła zdolna uśmiercać, jak też oczyszczać, uzdrawiać, a nawet ożywiać, o czym w odniesieniu do magicznych (ambiwalentnych) właściwości run informuje cytowany powyżej fragment sagi islandzkiej, spisanej na początku XII w. (runy sporządzone 
nieprawidłowo nabierały złych mocy magicznych; znano też runy dobre, sprzyjające człowiekowi) ${ }^{21}$.

W odnotowany powyżej nurt konotacji symbolicznych wpisuje się również ikonografia interesującego nas grzebienia ze Stroszek. Być może na okładzinach wspomnianego okazu - ekskluzywnego wytworu kultury skandynawskiej ze środkowego okresu wikińskiego - przedstawiono złośliwego olbrzyma Lokiego pod postacią łososia (a więc dużej, drapieżnej ryby), pętanego siecią przez bogów z grupy Asów (por. Edda poetycka, „Lokasenna”, epilog, s. 124; Snorri Sturluson, $E d d a$, „Gylfaginning” 50, s. 51-52). W tej sytuacji ornamentyka mogła symbolizować nieustanną walkę bogów i stworzonych na ich podobieństwo ludzi z zagrażającymi światu mocami zła. Przypomnijmy, iż szczególny udział w pochwyceniu Lokiego miał pogromca Olbrzymów, gromowładny bóg Thor, właściciel magicznego młota zwanego Mjollnir/Mjöllnir.

Oczywiście nie jest to jedyna dopuszczalna interpretacja znaczenia ornamentyki grzebienia ze Stroszek; w świetle cytowanej Eddy poetyckiej rysują się bowiem też inne rozwiązania symboliczno-semantyczne. I tak warto zwrócić uwagę na odnotowaną w „Pieśni Grimnira” („Grimnismál” 21, s. 70) zagadkową rybę pływającą w rzece Thjodwitnir, czyli w rzece „Wielkiego Wilka” (pod tym imieniem najprawdopodobniej kryje się śmiertelny wróg nordyjskich bogów - monstrualny wilk Fenrir, syn Lokiego; patrz Kempiński 2003, s. 206), którą tłumacz wspomnianej pieśni, wybitna znawczyni literatury staroskandynawskiej - A. Załuska-Strömberg (Edda poetycka, przypis na s. 70) - utożsamia m.in. z Midgardsormem, również potwornym potomkiem Lokiego. Jest to koncepcja prawdopodobna, zważywszy na to, iż w opisie pojedynku Thora ze wspomnianym Wężem Midgardu, utrwalonym w staroeddaicznej „Pieśni o Hymirze” (Edda poetycka, „Hymiskvida” 24-25, s. 104), „Bez trwogi wyciągnął męstwem sławny Thor / Jadowitego węża na burtę, / Młotem walił łba wierzchołek wysoki, / Rąbał wilczego brata srogiego. / Przepaści ryknęły, rafy echem zawyły, / Ziemia się stara zatrzęsła: / [...] / Potem spadła ta ryba w morze [wyróżnienie - M.K.]".

Nie można zatem wykluczyć, że ornamentyce znalezionego w Stroszkach grzebienia nadane zostały określone walory magiczne, poprzez skojarzenie symboliki ukrytej w wizerunkach, pokrywających uchwyt rzeczonego grzebienia, z mitycz-

21 W literaturze sformułowano też pogląd, zakładajacy utylitarny charakter germańskich run, których miano używać wyłącznie jako liter pozbawionych statusu magicznego (na ten temat Page 1998, s. 12). Koncepcji tej nie sposób zaakceptować. U ludów tzw. tradycyjnych, posiadających kulturę opartą głównie na przekazie oralnym, zatem również u Germanów późnej starożytności i Normanów epoki wikińskiej, pismo uznawane było za dar boski, o czym wzmiankowaliśmy powyżej (patrz też Lenerz-de Wilde 1987; Simek 2003, s. 220-224; Horbowicz i in. 2011, s. 20-21). 
nymi czynami boga Thora, w których bezkompromisowo rozprawia się on z mocami zła za pomocą magicznego młota. Była to broń miotana, rzucana przez Thora $\mathrm{w}$ przeciwnika $\mathrm{z}$ niezwykłą siłą (wrodzoną, nadzwyczajną moc boga podwajał bowiem magiczny „pas krzepy” oraz para żelaznych rękawic), przy czym wspomniany młot Mjollnir/Mjöllnir, dzięki posiadaniu magicznych walorów, zawsze powracał do właściciela (Kepmiński 2003, s. 206-208; Słupecki 2003, s. 129 i n.). Istniały więc silne związki łączące Thora $\mathrm{z}$ magią.

W tym kontekście przywołajmy raz jeszcze znalezisko XI-wiecznego (?) amuletu z m. Södra Kvinneby na Olandii (Szwecja; ryc. 7). Jest to miedziana, czworokątna blaszka z zaokrąglonymi narożnikami, o wymiarach $5,2 \times 4,9 \mathrm{~cm}$ (Jansson 1957), opatrzona wizerunkiem dużej, drapieżnej ryby, którą ze względu na wyraźne przewężenie ogona można ostrożnie utożsamiać z łososiem ${ }^{22}$. Według informacji XIII-wiecznej Eddy Prozaicznej autorstwa Snorri Sturlusona („Gylfaginning” 50, s. 51-52), która to informacja - sądząc z datowania obrazkowego kamienia z Ardre (X w.) - mogła mieć starszą genezę, łososie zyskały bowiem charakterystyczne przewężenie u nasady ogona, odkąd Thor pochwycił Lokiego, przemienionego w łososia, chwytając rybę nadzwyczaj mocnym uściskiem dłoni za ogon, gdy próbowała przeskoczyć sieć rozpostartą nań przez Asów. Przypomnijmy, rzeczone wydarzenie miało miejsce podczas ucieczki Lokiego z wodospadu Franangr, opisanej w epilogu staroeddaicznej „Lokasenny” („Kłótni Lokiego”). Na blaszce z Södra Kvinneby rybę wyryto w sąsiedztwie znaków runicznych (są również na odwrotnej powierzchni amuletu). Mimo iż treść obustronnej inskrypcji jest ciągle przedmiotem naukowej dyskusji, badacze pozostają zgodni, że złożony ze 143 run napis stanowi inwokację do Thora, który „,[...] gaeti hans meR them hamri [...]”, czyli „ochrania go swym młotem” (Perkins 2001, s. 54, 80; Słupecki 2003, s. 137-138). Na uwagę zasługuje fakt, iż runiczna blaszka z Södra Kvinneby, podobnie jak grzebień ze Stroszek, nie ujawnia wyobrażeń ani boga Thora, ani młota Mjollnira/ Mjöllnira, atrybutu tegoż boga, co w przypadku znaleziska z Södra Kvinneby nie dyskredytuje bynajmniej jego funkcji jako przedmiotu magicznego o cechach „amuletu Thora". W obu przypadkach zostały natomiast naniesione wizerunki dużych, drapieżnych ryb o charakterystycznie ukształtowanym ogonie.

Przypomnijmy, iż waleczny, gromowładny bóg Thor to typowy bohater sytuacji granicznych, w których chroni z narażeniem życia nie tylko zagrożony złem świat bogów, lecz również świat ludzi. $Z$ tego względu Thor doznawał szczególnej czci wśród normańskich wojowników, którzy wyruszając na wiking w celu pozyskania żywności (m.in. ryb, zboża, soli), łupów lub cennych surowców (np. futer, kłów morsa, poroża, bursztynu, metali) bądź kierowani chęcią wymiany towarów na obcych rynkach czy potrzebą kolonizacji nowych ziem, sami uczestniczyli w sytuacjach granicznych, wymagających szczególnej opieki sił nadprzyrodzonych.

${ }^{22}$ Zwężoną nasadę ogona ma też ryba wyobrażona na okładzinie grzebienia ze Stroszek (zob. ryc. $3: 1)$. 
Praktykowana w tym celu magia miała zabezpieczać uczestników dalekomorskich wypraw przed siłami wszechobecnego niebezpieczeństwa i/lub zła, czyhającymi nań w morskiej toni, zwłaszcza w chwili katastrofy statku grożącej śmiercią załogi, jak również w obcych krainach, w sytuacji kontaktu z przedstawicielami tamtejszych wspólnot, pozostającymi pod opieką własnych bóstw. Zapewne miała też - zgodnie z przekazem Ahmada ibn Faḍlāna (Kitāb, rozdz. [210b], s. 110) - gwarantować przychylność rodzimych bogów w działaniach bieżących. Odnotujmy, że według jednej $z$ hipotez runiczny amulet $z$ wizerunkiem ryby, odkryty w Södra Kvinneby, stanowił własność żeglarza/rybaka/kupca, generalnie „,człowieka morza”, który za pomocą inwokacji do uranicznego, ciągle podróżującego boga Thora i jego cudownego młota, zapisanej na amulecie, próbował uzyskać dobre wiatry (Perkins 2001, s. 80-81; zob. też Kempiński 2003, s. 207, gdzie informacja o pierwotnych funkcjach Thora). W literaturze podkreśla się szczególny udział gromowładnego Thora oraz wyrokującego Odina w przedchrześcijańskich wierzeniach skandynawskich „ludzi morza”, twórców cywilizacji wikińskiej (Słupecki 2003, s. 96 i n.).

Funkcję instrumentów magicznych, oddających właściciela indywidualnej opiece Thora, w pewnym sensie wręcz przymuszających boga do działania, skłonni jesteśmy przypisać też ozdobnym grzebieniom z poroża - elitarnym wyrobom kultury skandynawskiej z wczesnego średniowiecza - których uchwyt, czyli element mediacyjny, łączący właściciela przyboru z pożądanymi siłami sacrum, pokrywają bądź wizerunki drapieżnej ryby, zanurzonej w otchłani wodnej i ujarzmionej siecią (vide znalezisko ze Stroszek - ryc. 3:1), bądź wizerunki ukośnej kratki lub zakreślonych rombów, wyraźnie przypominające wyplecioną sieć rybacką (np. grzebienie typu „Birka” - ryc. 9:2-4, 6). (Antycypując dalszą część wywodu, podkreślmy jednak, iż nie są to jedyne konotacje religijne wspomnianych przedmiotów). Wśród użytkowników tego rodzaju grzebieni domyślamy się członków ówczesnych elit germańskich, zwłaszcza ludzi obeznanych z wojną, żeglugą i handlem. Wyznawali oni kult Thora, Wodana/Odina i Peruna, który w okresie chrystianizacji zastępowany był przez kult Chrystusa (na ten temat Simek 2003, s. 228 i n.; Dumézil 2008, s. 264 i n.).

Tytułem przykładu odnotujmy wykonany z poroża łosia grzebień typu IB-VIII-1a lub IB-VIII-3 według E. Cnotliwego (1973), reprezentujący formę typową dla elitarnej kultury skandynawskiej epoki wikińskiej, odkryty w Sigtunie (Uppland, Szwecja) i datowany na wiek XI (Ros 1992, s. 380, nr 578). Wpisuje się on w krąg znalezisk, których obecność w Skandynawii X-1. połowy XI stulecia (okres tzw. przełomu wiary) potwierdza istnienie wśród tamtejszych elit zjawiska dostosowywania wybranych, tradycyjnych elementów kultury materialnej do wzorców nowego wyznania - religii chrześcijańskiej. Na skrajnej płytce zębatej rzeczonego grzebienia naniesiono bowiem wizerunek niewielkiej, stojącej postaci ludzkiej przyobleczonej w ornat (?), z promienistą aureolą wokół głowy (może grzywą włosów) i rozpostartymi ramionami, którą badacze interpretują jako wyobrażenie Dzieciątka 

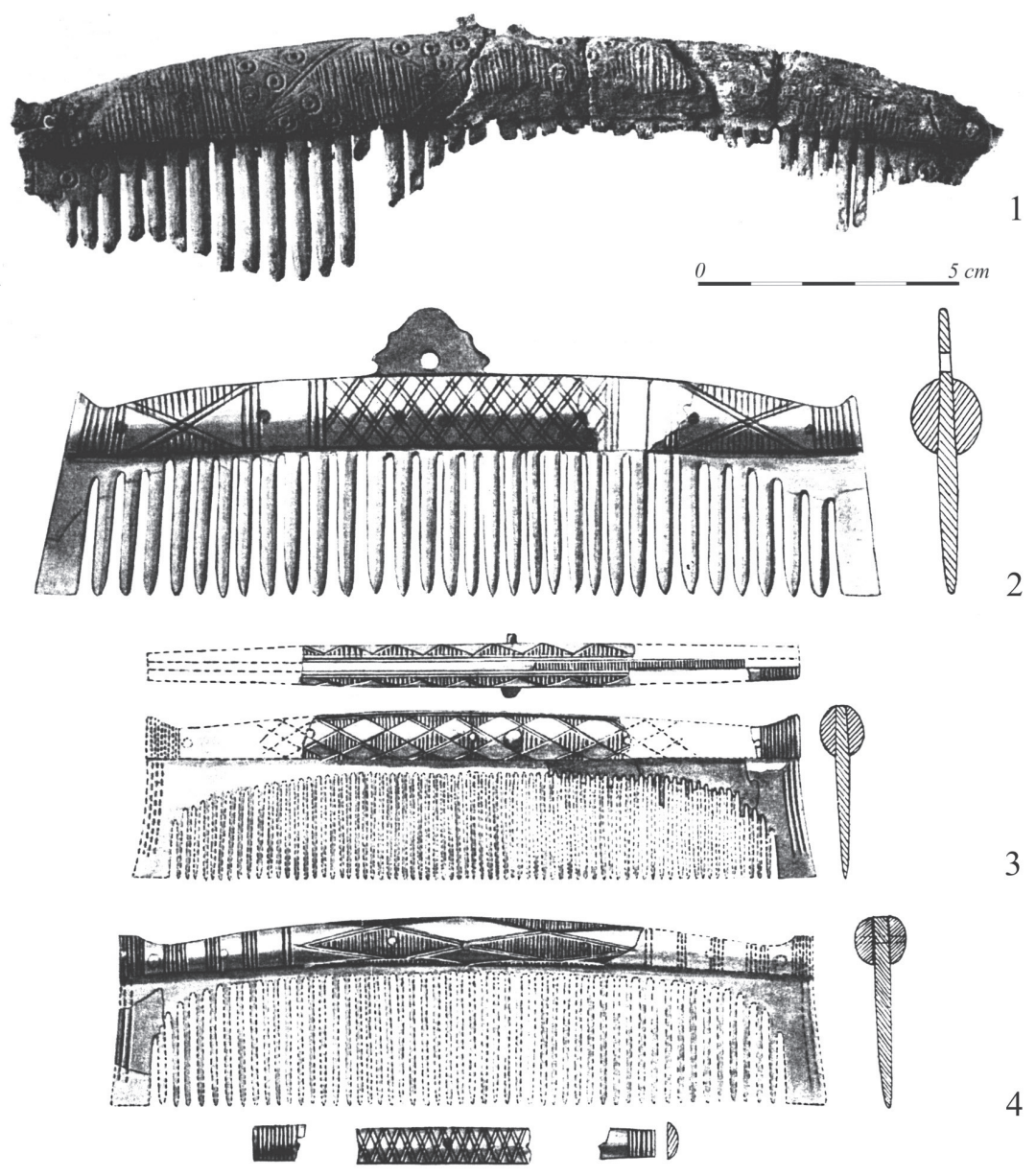

46

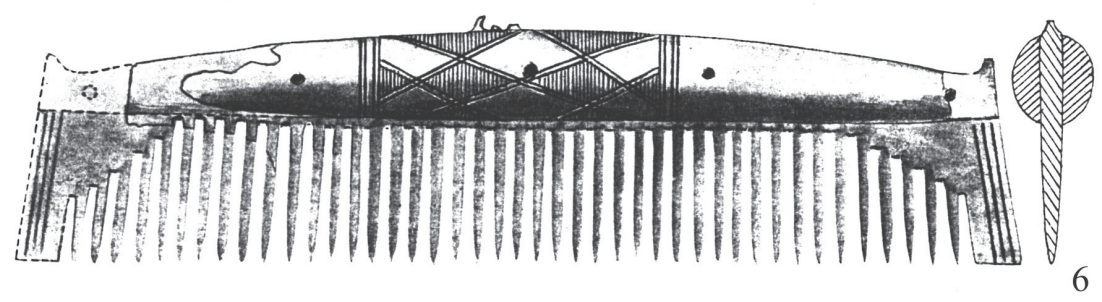

Ryc. 9. Grzebienie i domniemane zgrzebła z poroża (1-2), zdobione motywem ukośnej kratki lub zakreślonych rombów przypominających sieć, odkryte na cmentarzyskach z okresu wikińskiego w Björkö/Birce (Szwecja-Uppland); wybór znalezisk (1 - grób nr 944; 2 - grób nr 644; 3 - grób nr 209; 4-5 - grób nr 326; 6 - grób nr 581).Według Arbman 1940, tabl. 162:1-6 (z modyfikacją). Opracowanie komputerowe J. Sawicka 
Jezus (Liebgott 1992, s. 202, ryc. 1). W tym kontekście przypomnijmy obecne w kulturze skandynawskiej, począwszy od 2. połowy (?) X w., zjawisko kontaminacji wyobrażeń młota Thora z krzyżem Chrystusa, któremu towarzyszyła prawdopodobnie desemantyzacja znaku Thora, z czasem prowadząca do usunięcia tegoż z grupy symboli religijnych (na ten temat Gräslund 1983-1985; Wamers 1997; Słupecki 2003, s. 138; Hägg 2007, s. 103-104; Staecker 1999, tam m.in. polemika z poglądami Wamersa; Pedersen 2014 [Text], s. 231 i n.). Dodajmy, iż według P. Kuleszy (2007, s. 313) - zawdzięczamy mu analizę wspomnianego zagadnienia w ramach szerszych studiów problemowych - „Pojawieniu się zawieszek krzyża w Skandynawii towarzyszyła wzmożona produkcja amuletów w kształcie młota Thora. Wielu badaczy wskazuje, że jest to być może przejaw walki ideologicznej. Może być to faktycznie pozostałość po deklarujących wyraźnie swą przynależność dwóch ugrupowaniach. Jednak sprawa ta wymaga dalszych badań, szczególnie w świetle przytaczanych [...] przykładów współistnienia na jednym przedmiocie symboli młota i krzyża".

Na uwagę zasługuje też płaskorzeźbiona stela wapienna w kształcie prostopadłościanu, która pierwotnie wznosiła się na frankijskim grobie z 2. połowy VII w., odkrytym w m. Königswinter-Niederdollendorf w północnej Nadrenii-Westfalii (Niemcy; ryc. 10). Jedną z szerszych płaszczyzn steli wypełnia wyraźny, prymitywnie naniesiony wizerunek brodatego (?) mężczyzny w postawie stojącej, z długim skramasaksem u pasa (bronią, a zarazem atrybutem elitarnych wojowników frankijskich), z głową oraz górną częścią tułowia otoczoną przez próbujące pożreć go węże, ponadto z ozdobnym, podróżnym bukłakiem ustawionym przy nodze. Mężczyzna czesze prawą ręką zwisający z głowy pukiel (?) włosów. Czyni to za pomocą dużego grzebienia jednorzędowego o formie typowej dla ekskluzywnych grzebieni, znanych z frankijskiej strefy kulturowej tego czasu (por. Bertram 2002, tabl. 1F:1; 5F:2; 6A:7). Uważa się, iż wyobrażony na steli wojownik to zapewne zmarły pogrzebany w oznaczonym nią grobie, należący - wnosząc $\mathrm{z}$ formy pochówka - do zbrojnej elity ówczesnej Rzeszy Franków. Z kolei przeciwległą płaszczyznę steli zajmuje postać nagiego mężczyzny, również w pozycji stojącej, trzymającego w prawej ręce włócznię, z grzywą włosów na głowie, przypominającą promienisty wieniec (aureolę). Mężczyzna znajduje się pośrodku świetlistego nimbu, bezpośrednio na splecionych cielskach demonicznych węży (?), które depcze stopami.

Nawiązując do ustaleń J. Gieslera (2006; patrz też Piekarczyk 1979, s. 76-77), częściowo przez nas zmodyfikowanych, ostatni z wizerunków interpretujemy jako postać zmartwychwstałego Chrystusa, który upozowany na triumfującego herosa, zapewne Wodana - zwierzchniego boga wojny Germanów (por. Pesch 2015) ujarzmia siły zła, wdeptując demony w obręb Podziemia. Przywraca w ten sposób, niczym Sol invicti, właściwy porządek Światu, który w dniu śmierci Chrystusa na krzyżu został zaburzony przez tymczasowy triumf szatana.

Przeciwległy wizerunek zbrojnego mężczyzny można również odczytać w kontekście sytuacji granicznej, tym razem tożsamej z rytem przejścia $\mathrm{w}$ Zaświaty, 

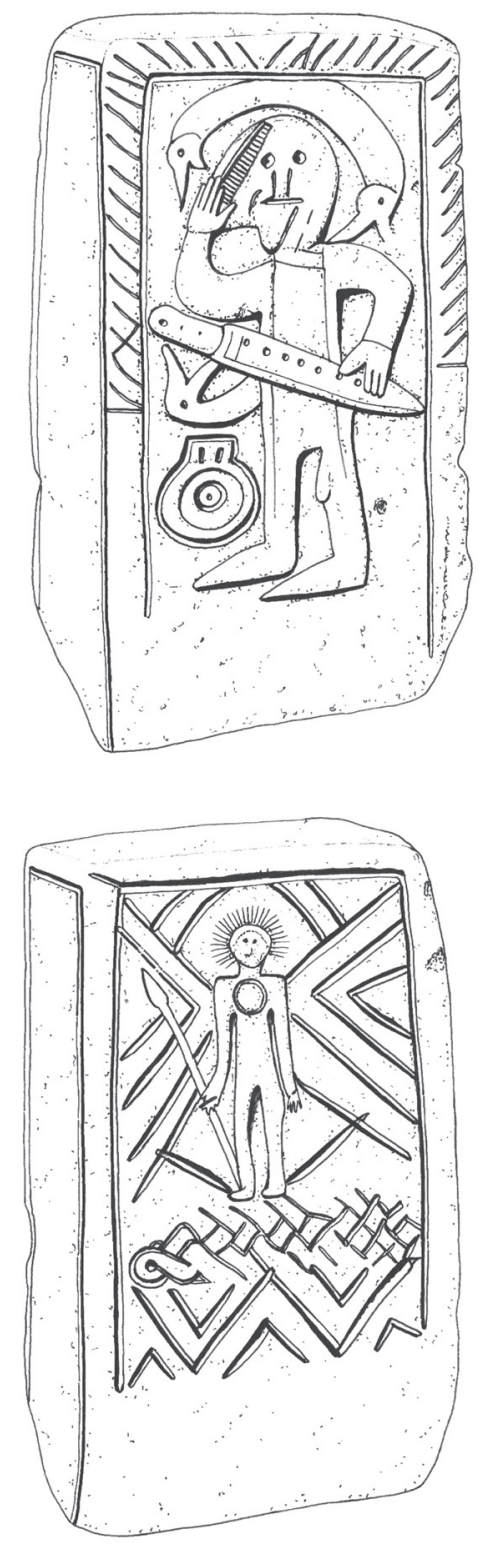

Ryc. 10. Königswinter-Niederdollendorf (Nadrenia-Westfalia, Niemcy). Uproszczony przerys płaskorzeźbionej, nagrobnej steli wapiennej z 2. połowy VII w., kultura merowińska (wymiary zabytku: wys. 53 cm, szer. 22-25 cm, gr. 16-19 cm). Według Giesler 2006, fot. na s. 107. Przerys. J. Kędelska 
który mimo chrześcijańskiego sensu (zob. sytuację opisaną powyżej, będącą dopełnieniem ikonografii nagrobka) odzwierciedla $\mathrm{z}$ pewnością starszą, pogańską symbolikę i obrzędy. Według zmodyfikowanego przez nas poglądu J. Gieslera (2006), wojownik czeszący głowę, oddaje się bowiem ewidentnym praktykom magii mającej wzmóc jego siły witalne, aby obmyty święconą wodą (?) z podręcznego bukłaka, tudzież wyposażony w potężny skramasaks, groźną w użyciu broń „białą” stosowaną do cięcia i kłucia, przygotowany był do walki z szatanem $\mathrm{w}$ chwili zmartwychwstania, gdy siły zła - w tumulcie Sądu Ostatecznego - będą usiłowały porwać odrodzonego z duszą człowieka na wieczne zatracenie.

$\mathrm{Z}$ opisanych przykładów wynika, iż grzebienie stanowić mogły jeden $\mathrm{z}$ istotnych wyznaczników cywilizacyjno-kulturowej tożsamości, budującej poczucie związku jednostki z większymi, nierzadko polietnicznymi ugrupowaniami o elitarnym charakterze (dotyczy zwłaszcza zbrojnych drużyn, a w odniesieniu do średniowiecza także „towarzystw” w typie rzemieślniczo-kupieckich gildii czy rybackich maszoperii), których członków łączyła zbliżona mentalność, a także wspólne zasady (prawo) i wierzenia, chociaż te ostatnie mogły być zróżnicowane, czego przykładem są drużyny ruskie (zob. Powieść minionych lat 18, s. 42; w tej kwestii różne jednak opinie archeologów: Musin 1999; 2005, s. 19 i n.; Michajlov 2016, s. 161-162). Dodajmy, że w interesującym nas okresie wikińskim, w tego rodzaju ugrupowaniach dominowali Skandynawowie (głównie poganie), a w okresie Vendel i początkowych stadiach starszego okresu wikińskiego (VII-1. połowa IX w.), w strukturach tych widoczni byli również kupcy-rzemieślnicy z państwa Franków, głównie Fryzowie, przynajmniej oficjalnie schrystianizowani (na ten temat Callmer 1998; Clarke i Heald 2002; Gustin 2004; Pedersen 2014 [Text], s. 223 i n., 264-267; Radtke 2017).

Tak sformułowanego poglądu nie można jednak odnosić do wszystkich segmentów społecznych „barbarzyńskich” ugrupowań wczesnośredniowiecznej Europy, zwłaszcza Germanów. Przypomnijmy, iż grzebieniami (m.in. typu „Birka”) posługiwały się także kobiety epoki wikińskiej, wchodzące wraz z mężczyznami oraz dziećmi w skład ówczesnych elit skandynawskich i ruskich (zob. Żak 1967, s. 310; Janowski 2015, s. 120, nr 348, s. 264, ryc. 90). Brakuje przesłanek, aby twierdzić, iż kult Thora praktykowały one na wzór mężczyzn ${ }^{23}$, jak również używały grzebieni wyłącznie w celach higienicznych.

Nie można zatem wykluczyć, że funkcja „rogowego” grzebienia, jako instrumentu niezbędnego dla osiągnięcia $\mathrm{w}$ określonej sytuacji granicznej zmiany „cywilizacyjnego” stanu jego posiadacza, w kulturze Germanów wczesnego średniowiecza nie zasadzała się na wyłącznych związkach symboliki przedmiotu z kultem wybranych bogów. Wynikała raczej $\mathrm{z}$ istoty grzebienia, jako przedmiotu wykonanego z poroża, mającego konotacje magiczne i/lub sakralne, który to in-

${ }^{23}$ Kwestie te, $\mathrm{z}$ uwzględnieniem interpretacji miniaturowych zawieszek w kształcie młota Thora pozyskanych z żeńskich grobów epoki wikińskiej, omawiają Gräslund 2007; Hägg 2007, s. 103 i n. 
strument, usuwając chorobotwórczy bród oraz insekty, potrafił w myśl ówczesnych przekonań skutecznie ujarzmić/zneutralizować zło, a porządkując głowę, umożliwić wzmocnienie/odrodzenie nadprzyrodzonych (pozytywnych) sił witalnych, skumulowanych w nieustannie odrastających włosach ludzkich (zagadnienie to rozwijamy poniżej). W tym przypadku tkwiąca $\mathrm{w}$ zdobnictwie grzebienia symbolika jego ikonograficznych treści mogła potęgować szczególne walory przedmiotu poprzez odwoływanie się do wybranych symboliczno-semantycznych kodów religijnych (zawartych na przykład w mitologicznych opisach czynów boga Thora), które miały istotny udział w budowaniu społecznej i etno-kulturowej tożsamości ludu. Mogła też odwoływać się do ogólniejszego sensu tejże symboliki, podzielanego niezależnie od uwarunkowań etnicznych, religijnych i temporalnych przez różne wspólnoty. I tak, w odniesieniu do rozważanej problematyki wskażmy na zakodowaną w znaku „sieci” symbolikę „,chwytania” czy ,ujarzmiania”, jak również na ukrytą w znaku ,żywiołu wodnego” symbolikę „uśmiercania” lub „oczyszczania/ odradzania", wreszcie na powszechnie zestawianą w kulturach ludzkich symbolikę „kumulowania” (jako świadectwa przychylności nadprzyrodzonych sił suwerennie zarządzających losem lub moderujących go) z przedstawieniem ryby w sieci znakiem „udanego połowu”.

Istoty opisanych zjawisk należy szukać w zbieżnościach mentalnych wczesnośredniowiecznych ludów „barbarzyńskiej” części Europy (por. Henderson 1987, zwłaszcza s. 71 i n.; Brown 1991, s. 63 i n.; Le Goff 1996, s. 42 i n.; Bates 2005, s. 13 i n.).

Według ówczesnych przekonań, Świat Ludzi funkcjonował bowiem uwikłany $\mathrm{w}$ różnorodne interakcje $\mathrm{z}$ mrocznymi mocami pochodzenia chtonicznego, łączonymi nierzadko $\mathrm{z}$ demonami, oraz $\mathrm{z}$ uranicznymi siłami sakralnymi, które przenikały towarzyszący człowiekowi Świat Natury (w zasadzie nierozpoznany i trudny do ujarzmienia), a także ekumenę tudzież samego człowieka. Zgodnie z trafną uwagą P. Browna (1991, s. 71): „Nad religijnym i intelektualnym życiem człowieka późnego antyku [i wczesnego średniowiecza - dop. M.K.] unosił się ostry odór niewidzialnej bitwy. Grzeszyć - nie znaczyło już tylko błądzić, ale dać się pokonać niewidocznym siłom. Błądzić - nie znaczyło mylić się, ale być nieświadomie kierowanym przez niewidzialną potęgę zła”. Siły sakralne zachowywały też kontrolę nad Czasem i Losem. Człowiek poruszający się w tak skonstruowanym mikrokosmosie (zarówno poganin, jak i chrześcijanin) postrzegał rzeczywistość z perspektywy homo symbolicus, próbując nie tyle określić rodzaj łączących go relacji z siłami nadprzyrodzonymi, w tym z sacrum, ile odczytując znaki, usiłował dociec ich sensu ${ }^{24}$. Mając świadomość, iż wspomniane siły tkwią ukryte pod powłoką

${ }^{24}$ Zdajemy sobie sprawę, że użyty przez nas termin homo symbolicus jest nie do końca adekwatny dla zdefiniowania człowieka wczesnośredniowiecznej Europy, który w przeciwieństwie do społeczeństw obecnych, sfery symbolicznej nie postrzegał jako autonomicznej części świata (por. Le Goff 1994; 1996; w kwestii kultury symbolicznej zob. Kmita 1982). Termin ów stosujemy jako opozycję terminu homo oeconomicus, którym człowiek wczesnego średniowiecza oczywiście też nie był. Spo- 
materii, próbował nawiązać za pomocą rytualnych obrzędów magicznych, religijnych lub religijno-magicznych szczególne kontakty z mocami pozytywnymi, w celu zapewnienia ochrony przed czyhającymi nań niebezpieczeństwem i/lub złem (zob. A.P. Kowalski 2014, s. 117-127). W tym celu posługiwał się m.in. instrumentami, których szczególne walory (magiczne, quasi-magiczne, religijne) miały ułatwić mu dostęp do magii i świata sacrum (por. Simek 2003, s. 213 i n.). Wśród nich były nie tylko paramenty i obiekty kultu, lecz również przedmioty użytkowe, które w określonych sytuacjach zyskiwały - według indywidulanych i społecznych przekonań - funkcje nadzwyczajne, m.in. o charakterze antydemonicznym. Przekształcając się samoczynnie w amulety, mogły zapewniać ochronę; jednocześnie mogły też odradzać czy wzmacniać witalne siły człowieka.

W nurt rzeczonych interpretacji wpisuje się również znaleziony w Stroszkach grzebień. Z racji wyobrażonych przedstawień okaz stanowić mógł własność zarówno poganina, jak i chrześcijanina. $\mathrm{W}$ okresie przełomu religijnego mógł pełnić też rolę tzw. zakamuflowanego identyfikatora wiary: nordyjskiej-pogańskiej lub ponadetnicznej-chrześcijańskiej. Ornamentyka grzebienia doskonale bowiem wpisuje się w symbolikę ikonograficznych schematów obu systemów religijnych ${ }^{25}$. W tym ostatnim przypadku grzebień ze Stroszek, zależnie od okoliczności, stanowić mógł znak emblematyczny, wpisujący właściciela w szersze ugrupowanie społeczne (por. dotyczące tegoż zagadnienia obserwacje etnograficzno-etnologiczne Wiessnera [1983]), przykładowo w „rzeszę” wyznawców Chrystusa. Jednocześnie mógł być źrodłem informacji, jako znak tzw. asertywny/apodyktyczny, który umożliwiał indywidualną identyfikację właściciela, m.in. w jego relacjach ze światem magii i sacrum.

Jak już nadmieniono, kultura skandynawska wczesnego średniowiecza nie ujawniła grzebieni ornamentowanych motywem ryby, mimo iż znane są tego rodzaju artefakty pochodzenia normańskiego, pokryte rytymi wizerunkami wężowatych potworów lub ozdobione plastycznymi głowami stylizowanych zwierząt-monstrów, nierzadko z otwartymi paszczami (zob. Arbman 1944, s. 14 i n., ryc. 5-9; K. Ambrosiani 1981, s. 47, ryc. 18; Gräslund 2007, s. 91-92, ryc. 2b).

łeczności wczesnośredniowieczne postrzegały świat głównie na zasadzie magiczno-mitycznej, przy czym uważa się (w zgodzie z ustaleniami etnologów-funkcjonalistów i strukturalistów), że świadomość tychże społeczności ukierunkowana była praktycznie (por. Kmita 1989, gdzie zagadnienie rozpatrywane $\mathrm{z}$ perspektywy teorii filozofii). Zob. też przypis $6 \mathrm{w}$ niniejszym artykule.

25 O mechanizmach i kulturowych przejawach chrystianizacji „,barbarzyńskich” ludów wczesnośredniowiecznej Europy (ze szczególnym uwzględnieniem Germanów) zob. Gräslund 1983-1985; 2001; Simek 2003, s. 130 i n., 228 i n.; Hägg 2007; Dumézil 2008; Pedersen 2014 (Text), s. 231 i n.; Tesch 2015; Michałowski 2016a; Pleszczyński 2016. 
Relikty dwu wczesnośredniowiecznych grzebieni z poroża, z rytym motywem ryby na okładzinach, znamy natomiast $\mathrm{z}$ terenów Fryzji, $\mathrm{z}$ obszaru sąsiadującego ze Skandynawią (Roes 1963, s. 19-20, tabl. 24:3; 32:3)26. Oba zabytki to okazy zaopatrzone w pojedynczy rząd zębów, złożone $\mathrm{z}$ trzech warstw nitowanych płytek, z których zewnętrzne - w formie litych okładzin bocznych, stanowiących uchwyt grzebienia - mają grzbiet nieznacznie trójkątny lub łukowaty, natomiast podstawę lekko wypukłą bądź nieznacznie wklęsłą.

Pierwszy grzebień (ryc. 3:2) - wykonany z białawego poroża, o całkowitej długości około $25 \mathrm{~cm}$ i maksymalnej wysokości około 3,3 $\mathrm{cm}$ - reprezentuje typ IB-VII-7b według E. Cnotliwego (1973). Jego łukowate okładziny pokrywa stylizowany motyw ryby o wyraźnie zarysowanej głowie, z wypełniającą jej tułów parą symetrycznie splecionych czterech węży. Końce wężowatych splotów wieńczy stylizowana głowa $\mathrm{z}$ otwartą paszczą, przypominająca głowy wyobrażone na okładzinach grzebienia ze Stroszek. Jest to wyrób luksusowy.

Z drugiego grzebienia (ryc. 3:3) zachowała się tylko trójkątna okładzina boczna o długości $16 \mathrm{~cm}$ i maksymalnej wysokości $2,1 \mathrm{~cm}$, którą z dużą dozą prawdopodobieństwa można uznać za fragment okazu typu IB-VII-7a lub $7 \mathrm{~b}$ według E. Cnotliwego (1973; analogie zob. Roes 1963, tabl. 21:3; 23:3; 26:1). Centralną partię płytki wypełnia motyw dużej, stosunkowo realistycznie odwzorowanej ryby (sądząc z paszczy - drapieżnej), o tułowiu pokrytym rzędem rombowatych łusek, przesłoniętym pośrodku siecią, którą wyobrażono jako regularną, ukośną kratkę złożoną z szachownicy gęsto zakreskowanych rombów. Krótsze, pionowe krawędzie sieci wyodrębnione zostały bordiurą złożoną z gęstej, ukośnej kratki w obramowaniu podwójnych linii pionowych. Grzebień ów stanowi pod względem ornamentyki najbliższą analogię do znaleziska ze Stroszek, przy czym oba okazy łączy zarówno podobieństwo $\mathrm{w}$ zakresie kompozycji, jak i w sposobie wykonania zdobnictwa (dodajmy, iż okładziny grzebieni typu IB-VII-7 oraz IB-VIII-1 są zbliżone kształtem i wymiarami).

Ustalono, iż grzebienie typu IB-VII-7a lub 7b to wyroby wyspecjalizowanych grzebienników fryzyjskich, produkowane co najmniej do końca IX w. (Cnotliwy 1973, s. 122-124, ryc. 49). Opisane powyżej grzebienie (zwłaszcza ostatni) ujawniają podobieństwo do trójwarstwowych grzebieni jednorzędowych, datowanych zasadniczo na przełom okresu merowińskiego i karolińskiego (VIII/IX w.), których okładziny boczne wypełnia ryty motyw przypominający rybę w sieci (Roes 1963, s. 18, tabl. 20:2; Schmid 1969, s. 258 i n., ryc. 2:1). Znaleziska wspomnianych grzebieni zostały również stwierdzone na terenie Fryzji, co w świetle poczynionych ustaleń uznajemy za okoliczność nieprzypadkową.

${ }^{26}$ Lista zdobionych w ten sposób wczesnośredniowiecznych grzebieni z terytorium Fryzji może być dłuższa; do analizy wybraliśmy tylko znaleziska pokryte motywami, których interpretacja nie budzi wątpliwości. 
Obecność w materiale fryzyjskim wyraźnych analogii stylistycznych do grzebienia ze Stroszek nie przesądza jednak o pochodzeniu tegoż okazu z regionu basenu Morza Północnego. Forma zabytku, technika wykonania, jak również elementy zdobnicze w postaci centralnie umieszczonego wątku ukośnej kratki, wreszcie fakt, iż motyw realistycznie wyobrażonej ryby znany był Normanom, pozwalają podtrzymać wcześniejszą opinię o skandynawskiej genezie grzebienia. Przypuszczamy, że ornamentyka okazu była inspirowana produktami grzebienników fryzyjskich z IX ewentualnie 1. połowy X w., którzy czerpali z tradycji postantycznej (por. Petković 1995), twórczo przetworzonej przez merowiński krąg kulturowy strefy frankońskiej, górno- i środkowonaddunajskiej oraz nadreńskiej (Roes 1963; Cnotliwy 1973). Grzebień z osady w Stroszkach może zatem potwierdzać tezę, sformułowaną m.in. przez E. Cnotliwego (1973; 1993) i J. Callmera (1998), o wpływach fryzyjskiego rzemiosła rogowniczego na grzebiennictwo skandynawskie okresu wikińskiego.

W kontekście przytoczonych analogii warto nadmienić też o ornamentowanym igielniku z poroża w kształcie ryby (ryc. 11), który został odkryty podczas badań archeologicznych w 2012 r. w Wolinie (Janowski 2014, s. 4 i n., zwłaszcza s. 27, fot. 37).

Igielnik zalegał w reliktach wczesnośredniowiecznego portu datowanych na wiek X. Prezentuje on typowy dla produkcji rzemieślniczej wysoki standard wykonania; być może został wyrzucony jako przedmiot zdekompletowany. W otworze igielnika brakuje bowiem „grzybkowatego” czopu, zamykającego pierwotnie pojemnik. Przed wysunięciem czop zabezpieczała pozioma zatyczka, tkwiąca w specjalnie wywierconym dlań niewielkim otworze, który nosi ewidentne ślady dawnego uszkodzenia (mogło ono zadecydować o zdekompletowaniu przedmiotu). Analiza stylistyczna igielnika pozwala łączyć go z rzemiosłem rogowniczym krajów basenu Morza Bałtyckiego lub basenu Morza Północnego. Szczególne podobieństwo w zakresie motywów zdobniczych, które pokrywają powierzchnię przedmiotu, ujawniają wyroby (m.in. grzebienie) wyspecjalizowanych rogowników wczesnośredniowiecznych z obszaru Fryzji, zwłaszcza z wczesnomiejskiej osady w Dorestad (zob. Roes 1963, tabl. 26:7; 1965, tabl. 24:184; 25:188; 26:200; 29:220). Chodzi o wykonane bardzo starannie za pomocą cyrklowatego świderka tzw. oczka, tudzież o wsuwane trójkąty, naniesione za pomocą rylca lub noża (w przypadku „wolińskiego" igielnika imitują one rybie łuski oraz karbowanie rybiej płetwy ogonowej), dalej o pasmo dookolnych żłobków sporządzone rylcem lub cienką piłką, a także o poziome nacięcia wykonane zapewne nożem, które w powiązaniu ze wspomnianymi żłobkami tworzą ozdobną bordiurę wokół otworu na czop, zamykający igielnik. Uchwycone relacje stylistyczne, wskazujące na obszar Fryzji, w połączeniu z nawiązującą do ryby formą przedmiotu, nie wydają się przypadkowe. $Z$ ostatecznymi wnioskami, co do pochodzenia igielnika, należy jednak poczekać do ukończenia przez archeologów finalnego opracowania ba- 


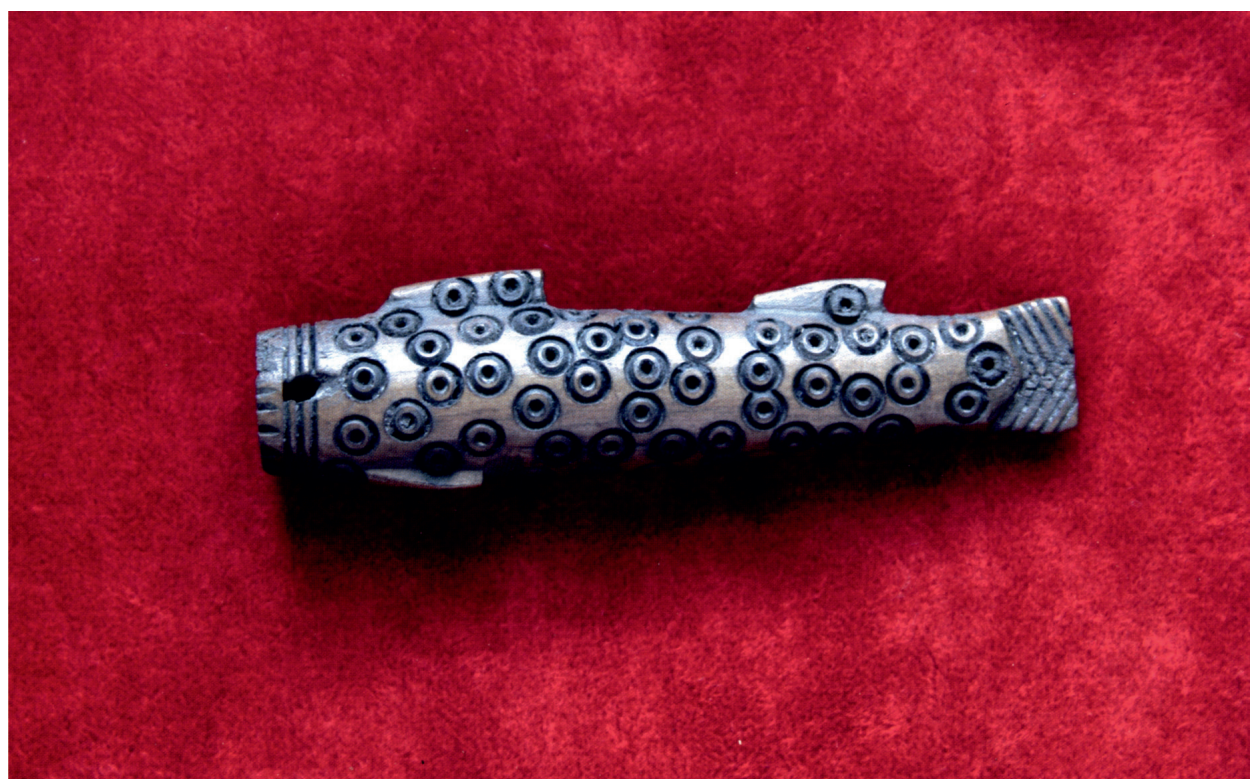

Ryc. 11. Igielnik z poroża w kształcie ryby, znaleziony w reliktach portu w Wolinie datowanych na X w. Według Janowski 2014, fot. 37. Fot. A. Janowski

dań portu $\mathrm{w}$ Wolinie ${ }^{27}$. Dodajmy, że w znanym nam materiale porównawczym nie stwierdziliśmy igielnika podobnego do okazu z Wolina (według Janowskiego [2014, s. 27] opisany zabytek to piąte tego rodzaju znalezisko znane nauce; analogii nie wyszczególnił).

Wyrobem jednostkowym lub tzw. krótkiej serii wydaje się również grzebień ze Stroszek, odbiegający ornamentyką od współczesnych mu zestandaryzowanych produktów rzemiosła rogowniczego (Brzostowicz 1996, s. 271-272). Należy zauważyć, że grzebienie potraktowane w wyżej wymieniony sposób rejestrowane są wśród znalezisk typu IB-VIII-1 według E. Cnotliwego (zob. K. Ambrosiani 1981, s. 68 i n., ryc. 36, tam okładzina grzebienia z cmentarzyska w Birce - odlana z pozłacanego brązu, zdobiona podwójną plecionką, być może przedstawiającą węże; Gräslund 2007, s. 91-92, ryc. 2b, tam grzebień z reliktów wczesnomiejskiej osady w Birce, stan. Svarta jorden - z wyrytym w skandynawskim stylu Mammen motywem splecionego węża). Są to okazy luksusowe.

We wspomniany nurt produkcji rzemieślniczej wpisuje się również jednorzędowy, trójwarstwowy grzebień z poroża, spojony żelaznymi nitami, który odkryty

27 Przygotowanie wspomnianego opracowania, które zawierać będzie również wyniki porównawczej analizy zabytków, planuje A. Janowski z Ośrodka Archeologii Średniowiecza Krajów Nadbałtyckich IAE PAN w Szczecinie. W latach 2011-2013 wspomniany badacz kierował wykopaliskami na wymienionym stanowisku (uprzejma informacja prof. A. Janowskiego, za którą bardzo dziękuję). 
został w kulturowej warstwie nr XXXII na Rynku Warzywnym w Szczecinie, także zdobiony motywem zoomorficznym (Cnotliwy 1973, s. 139, 154-155, ryc. 56a; Kowalska i Dworaczyk 2011, s. 315 oraz aneks 4, ryc. 238:6). Grzebień ma około $20 \mathrm{~cm}$ długości. Jest to wyrób luksusowy, noszący ślady uszkodzenia i prawdopodobnie doraźnie naprawiony, w związku z czym ma wtórnie skrócone okładziny boczne (?) oraz tylko jedną z dwu symetrycznie rozłożonych skrajnych płytek zębatych, wyraźnie wystającą ponad okładziny uchwytu i uformowaną w kształcie stylizowanej głowy końskiej (ryc. 12:1). W nowszej literaturze przedmiotu warstwę nr XXXII określa się jako pozostałość najstarszej zabudowy nadodrzańskiego, gospodarczego członu wczesnośredniowiecznego Szczecina, wchodzącego w skład tamtejszego ośrodka wczesnomiejskiego. Relikty datuje się na 3. dekadę $\mathrm{X}$ w., natomiast zalegające pod nimi ślady niwelacji nadbrzeżnych płycizn Odry, wraz z pozostałością łodzi klepkowej leżącej pod grubym pokładem mułu rzecznego (nadcalcowa warstwa nr XXXIII), synchronizuje się najwcześniej z 2. dekadą X stulecia (Kowalska i Dworaczyk 2011, s. 41-45, 357-371 oraz s. 27, tabela 1; patrz też Cnotliwy i Łosiński 1995; Łosiński 2008, s. 101 i n.). W literaturze omawiany grzebień uznany został za ,,[...] bezcenne znalezisko spinające grzebienie fryzyjskie z pomorskimi” (Cnotliwy 1973, s. 139). Z tego też względu, zważywszy na opisane powyżej fryzyjskie analogie grzebienia ze Stroszek, wymaga on obszerniejszej charakterystyki.

Wspomniany badacz zaliczył go do typu IB-VIII-4 (Cnotliwy 1973, s. 154-155), podkreślając, iż jest to odkrycie jednostkowe, mające tylko względne analogie w dwu grzebieniach prawdopodobnie pochodzenia skandynawskiego, stwierdzonych w Londynie i Lundzie. Grzebień określił jako hybrydę, którą wykonano około przełomu IX i X w., zapewne w rejonie ujścia Odry, pod wpływem inspiracji wyrobami grzebienników z Fryzji i Skandynawii, z udziałem określonej ornamentyki rytej, popularnej - jego zdaniem - w grzebiennictwie zachodniopomorskim tego czasu (Cnotliwy 1973, s. 139). Koncepcji E. Cnotliwego nie podważamy w ujęciu ogólnym; można jednak skorygować ją w zakresie szczegółowym, korzystając $\mathrm{w}$ tym przypadku z wyników analizy nowszych materiałów porównawczych.

Identycznie jak E. Cnotliwy, grzebień „szczeciński” uznajemy za unikatową hybrydę z końca IX lub początku X w., powstałą w wyniku adaptacji trzech elementów składowych, typowych nie tyle dla wczesnośredniowiecznego grzebiennictwa Słowian nadbałtyckich, ile dla grzebienników działających na obszarze Skandynawii, głównie w jej południowo-zachodniej części, oraz w rzemieślniczo -handlowych ośrodkach na terenie Anglii. Uważamy bowiem, iż omawiany grzebień został wykonany raczej w Hedeby lub Yorku, zapewne pod wpływem inspiracji grzebieniami franko-fryzyjskimi, co nie oznacza definitywnego odrzucenia przez nas hipotezy E. Cnotliwego. Za „,północną” proweniencją grzebienia przemawiają jednak bliskie analogie do formy jego poszczególnych elementów składowych tudzież zdobnictwa. I tak, obie okładziny boczne grzebienia „,szczecińskiego" - podobne (z wyjątkiem wymiarów) do okładzin egzemplarza ze Stro- 

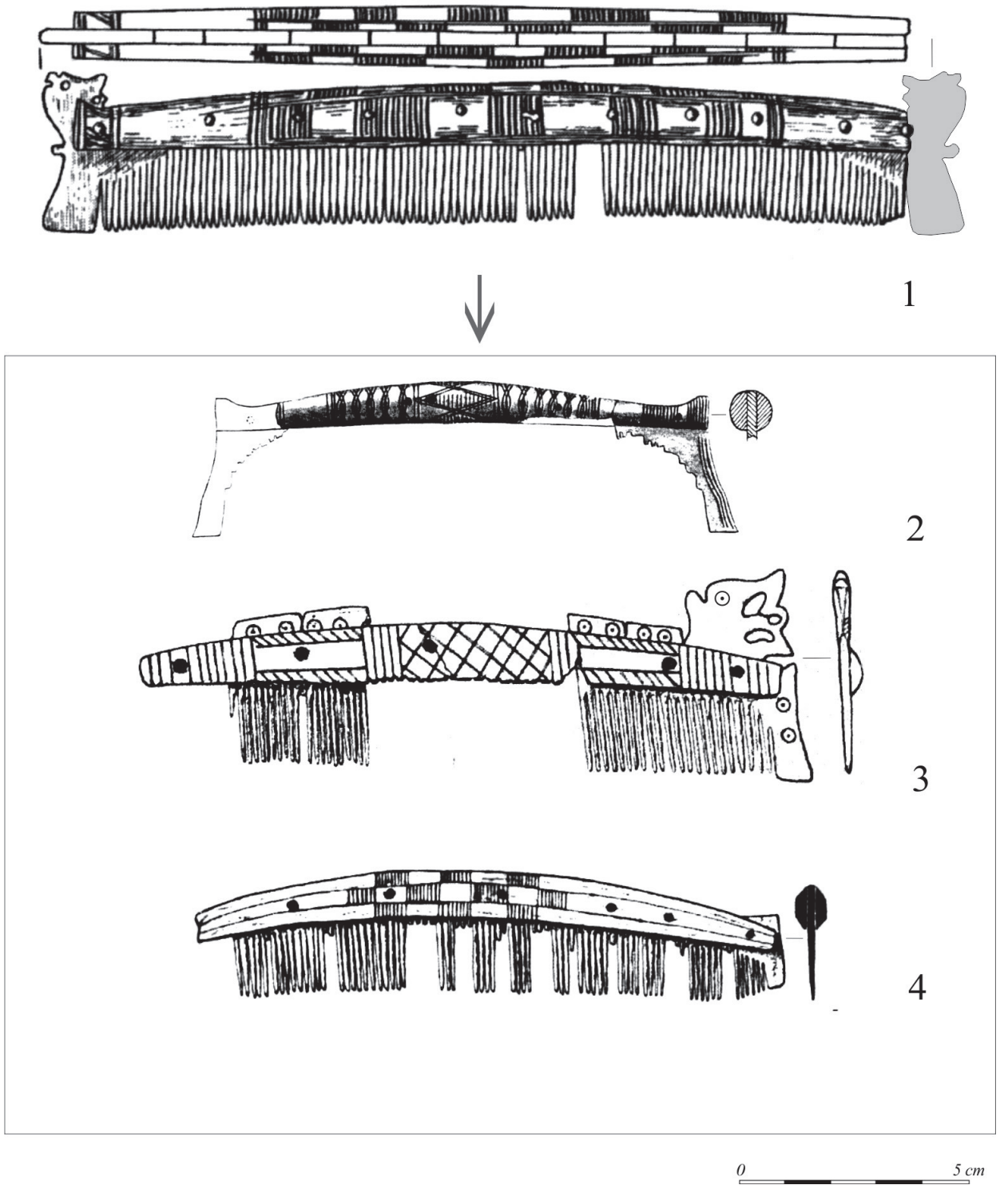

Ryc. 12. Grzebień z poroża odkryty na Rynku Warzywnym w Szczecinie (woj. zachodniopomorskie), w warstwie $\mathrm{nr} 32 \mathrm{z}$ 3. dekady X w. (1), wraz z analogiami do formy i ornamentu jego okładzin bocznych (2 - Björkö/Birka, Szwecja-Uppland, grób nr 137, środkowy okres wikiński; 4 - York, Wielka Brytania, okres wikiński), oraz analogią do jego skrajnych płytek zoomorficznych (3 - Londyn, Wielka Brytania, okres wikiński). Opracował M. Kara na podstawie: 1 - Kowalska, Dworaczyk 2011, ryc. 238:6 (z modyfikacją); 2 - Arbman 1940, tabl. 164:12; 3-4 - MacGregor 1985, ryc. 50h, i. Przerys. J. Sawicka 
szek (!) - są charakterystyczne dla skandynawskich grzebieni typu IB-VIII-1 lub 2 według E. Cnotliwego (1973; przypomnijmy: tożsame z typem „Birka” oraz grupą B:1-2 według K. Ambrosiani [1981] i typem 6 według S.P. Ashby [2010]), które synchronizuje się ze środkowym i młodszym okresem wikińskim (ryc. 12:2). Z kolei w przypadku zoomorficznej, skrajnej płytki zębatej grzebienia „szczecińskiego" bardzo wyraźne zbieżności w zakresie jej kształtu ujawnia luksusowy grzebień typu 2b według S.P. Ashby (2010; w schemacie typologicznym E. Cnotliwego [1973] jest to okaz zbliżony do typów IB-VII-6d oraz IB-VII-9b), odkryty w Londynie i pochodzący najpóźniej z przełomu starszych oraz młodszych faz wczesnego średniowiecza, zapewne wzorowany na wyrobach franko-fryzyjskich (por. Roes 1963, s. 19-22, tabl. 24:6; 25:5; 26:6) (ryc. 12:3). Z Yorku pochodzi też grzebień typu IB-VII-7b według E. Cnotliwego (1973) lub typu 7 w schemacie S.P. Ashby (2010), którego forma ma wyraźne odpowiedniki w luksusowych okazach fryzyjskich z wczesnego średniowiecza (por. Roes 1963, s. 19-21, tabl. 22-23; McGregor 1985, s. 90, ryc. 50i). Według S.P. Ashby (2007, s. 3, 5) odkryte w Yorku grzebienie typu 7 to okazy pochodzące z X i XI stulecia. Ornament ryty, pokrywający okładziny boczne wspomnianego grzebienia $z$ Yorku, jest bardzo podobny do szachownicowego ornamentu, jaki został naniesiony na okładziny grzebienia „szczecińskiego" (ryc. 12:4). Dodajmy, iż w przypadku Yorku tego rodzaju ornament notowany jest także na innych znalezionych tam grzebieniach wczesnośredniowiecznych, datowanych na X-XI wiek, m.in. na okazach typu IB-VII-7 według E. Cnotliwego (1973, s. 126; zob. również MacGregor, Mainman, Rogers 1999, ryc. 886:7572, 7579; 890:6783; Ashby 2010, s. 6, typ 8b). Podobne zdobnictwo ujawniają też grzebienie odkryte w Haithabu, łączone z okresem wikińskim (zob. Jankuhn 1943, s. 148 i n., ryc. 751; 76d, f; Tempel 1970, s. 41 i n., ryc. 4:2), a także okazy ze Srebrnego Wzgórza w Wolinie. Sądząc z chronologii znalezisk, $\mathrm{w}$ wolińskich pracowniach grzebienniczych ornament szachownicowy stosowany był raczej dopiero od końca X w. (Cnotliwy 1973, s. 109; patrz też Cnotliwy, Łosiński i Wojtasik 1986, s. 70-72 oraz tabela 1; 2, gdzie nowe datowanie warstw kulturowych wczesnośredniowiecznego Wolina) ${ }^{28}$.

Wymienione powyżej grzebienie odkryte w Birce oraz na Rynku Warzywnym w Szczecinie, informujące o szerszym kontekście kulturowym i społecznym grze-

${ }^{28}$ Z Wolina pochodzi też luksusowy grzebień z poroża, zdobiony ornamentem szachownicowym, odkryty na Rynku podczas badań archeologicznych w 1934 r. (Wilde 1953, tabl. Vb:7; Cnotliwy 1973, s. 125 , ryc. 48c, tam błędna lokalizacja zabytku). Przedmiot zalegał we wczesnośredniowiecznej warstwie kulturowej nr 4/5, którą po weryfikacji datuje się orientacyjnie na 2. połowę IX w. (Cnotliwy, Łosiński i Wojtasik 1986, s. 65-66 oraz tabela 1; 2). W schemacie taksonomicznym grzebieni, autorstwa E. Cnotliwego (1973, s. 124-128), okaz reprezentuje typ IB-VII-7f. Jest to najprawdopodobniej „import”, pochodzący z obszaru południowo-zachodniej Skandynawii (w rachubę wchodzi zwłaszcza ośrodek w Hedeby) lub z sąsiednich terenów dolnosaskich, względnie ze skandynawskich emporiów w Anglii (np. York). Za proponowaną atrybucją zabytku przemawiają materiały porównawcze (Cnotliwy 1973, s. 126, tamże dalsza literatura; Jankuhn 1943, s. 148 i n.; Tempel 1970, s. 39 i n.; MacGregor, Mainman i Rogers 1999, s. 1923 i n.). Nie można wykluczyć też ewentualności, że grzebień został wykonany w Wolinie przez obcego rzemieślnika, aczkolwiek jest to tylko spekulacja. 
bienia ze Stroszek, to okazy istotne dla naszych rozważań. Przypomnijmy, ze znaleziskiem wielkopolskim wspomniane grzebienie łączy zbliżona chronologia i proweniencja, to samo tworzywo, niemal identyczna technika i wysoki bądź dobry poziom wykonania, jak również podobieństwo formy ${ }^{29}$, wreszcie wyraźna obecność zdobnictwa zoomorficznego o różnym stopniu stylizacji. Okazy te podbudowują tezę o zaistnieniu około przełomu IX i X w. w Europie Północnej ekskluzywnych wyrobów rzemiosła rogowniczego, które z racji liczebności oraz braku standaryzacji formy i/lub zdobnictwa uznać można za produkty tzw. krótkich serii, o czym wzmiankowaliśmy powyżej. W zarysowanym układzie na szczególną uwagę zasługuje grzebień odkryty w Szczecinie, ponieważ jednoznacznie potwierdza on obecność tego rodzaju wyrobów na terenie Pomorza w 1. połowie X wieku. Dla odkrytej w Stroszkach pod Gieczem osady wczesnośredniowiecznej, funkcjonującej m.in. w X stuleciu, jest to okoliczność ważna. Dotyczy bowiem obszaru (obecna centralna Wielkopolska), którego ludność utrzymywała w tym czasie żywe relacje kulturowe, gospodarcze i polityczne z mieszkańcami Pomorza (Losiński 1999, s. 129 i n.; 2008, s. 40, 134; Kara 2009, s. 229, 253 i n.).

Dodajmy, że w kulturze ludów Europy Północnej wczesnego średniowiecza, zwłaszcza Skandynawów, fenomen produkcji krótkich serii dotyczył nie tylko ekskluzywnych grzebieni z IX/X-X/XI wieku. To samo zjawisko ujawniają też znaleziska elementów elitarnego uzbrojenia lub stroju. Dotyczy to zwłaszcza paradnych mieczów czy bogato inkrustowanych toporów oraz grotów włóczni, datowanych na środkowe i młodsze stadia okresu wikińskiego (zob. Iversen, Näsman i Vellev [red.] 1991; Kara 2016a, s. 377; 2016c, s. 119-124). Kryteria ekskluzywnych wyrobów tzw. krótkich serii spełniają też niektóre pasy skórzane pochodzące z tego czasu. Uwaga dotyczy zwłaszcza okazów zaopatrzonych na wzór koczowniczy w niewielkie, ozdobne aplikacje odlane z kolorowych metali, których koniec rzemienia wzmacnia „okucie” z wyrytym znakiem rodowym Rurykowiczów, w formie mniej lub bardziej stylizowanej tamgi (por. Hedenstierna-Jonson i Holmquist Olausson 2006; Krysztofiak 2013; Kara 2016a, s. 376-377; Yotov 2018, s. 471, 481, ryc. 8:1). Wśród wymienionych przedmiotów wcale nierzadko notuje się hybrydy powstałe w środowisku Skandynawów lub Rusów pod wpływem kultury euro-azjatyckich koczowników, Anglo-Sasów, Iro-Szkotów i/lub Bizancjum. Pod względem genezy wspomniane artefakty wpisują się w zmaterializowane nurty kultury elitarnej, odzwierciedlające przemiany cywilizacyjno-kulturowe i społeczne, jakie zachodziły w X w. na terenie Europy Północnej i Wschodniej (Kara 2016a, s. 378-379), w związku z budową przez tamtejszych charyzmatycznych wodzów scentralizowanych organizmów wczesnopaństwowych - zalążków średniowiecznych monarchii Normanów (Norwegów), Danów, Swewów i Rusów. Dodajmy, że

${ }^{29} \mathrm{~W}$ przypadku grzebienia „szczecińskiego” zbieżności w zakresie formy z okazem odkrytym w Stroszkach są najmniejsze, bo ograniczają się do kształtu okładzin bocznych. Dotyczą jednak istotnego elementu każdego grzebienia, jakim jest jego uchwyt. 
wspomniane transformacje stanowiły składowe wielowymiarowych procesów o konsekwencjach gospodarczych i kulturowych.

I tak, w VIII-IX stuleciu obraz cywilizacji obszaru Europy Północnej i nadbałtyckiej części Europy Środkowo-Wschodniej kształtowały głównie relacje gospodarcze między tamtejszymi emporiami i ośrodkami wczesnomiejskimi; relacje te determinowały też formy ówczesnej komunikacji społecznej (por. Brandt, Müller-Wille i Radtke [red.] 2002; Herrmann 2003; Müller-Wille 2003; Gustin 2004; Łosiński 2008, s. 125 i n.; Skre [red.] 2008, s. 327-355; Kleingärtner 2014). W tym nurcie kontaktów ważną rolę odgrywały zunifikowane i zestandaryzowane znaki elitarnej kultury - na przykład luksusowe, fryzo-skandynawskie grzebienie „rogowe" typu A1-A2 według K. Ambrosiani (1981, s. 25, ryc. 9), będące produktami tzw. długich serii.

Odmiennie można zinterpretować sytuację kulturową na tym obszarze w X i początkach XI wieku. Poświadczone wśród tamtejszych znalezisk ekskluzywne wyroby tzw. jednostkowe bądź krótkich serii - m.in. ozdobne grzebienie proweniencji skandynawskiej, zwłaszcza niektóre okazy typu B1:1-2 według K. Ambrosiani (1981, s. 25, ryc. 9), w zakresie formy i częściowo zdobnictwa bardzo podobne do znaleziska ze Stroszek - sugerują istnienie w granicach tegoż regionu silniejszej niż w wieku IX wymiany ceremonialnej, opartej na cyrkulacji unikatowych i drogocennych towarów-znaków między konkurującymi ze sobą przedstawicielami ówczesnej elity społecznej, w tym elity władzy. Wspomnianą wymianę kształtowały relacje natury symbolicznej, determinowane prestiżem. Uważa się, iż w ramach określonych obrzędów i rytuałów utrwalały one różnorodne układy doraźne (także polityczne, handlowe i gospodarcze) zawierane bądź między arystokracją zaangażowaną $\mathrm{w}$ etapowy handel dalekosiężny, bądź między możnymi a kupcem-wytwórcą, bądź między wodzem, władcą lub rodem panującym a jego „klientelą”, wreszcie między silnie rywalizującymi ze sobą władcami ${ }^{30}$ (por. Iversen, Näsman i Vellev [red.] 1991).

Podobną sytuację notujemy w Europie Północnej w okresie przełomu starożytności i średniowiecza, jak też w początkowych stadiach okresu Vendel (zasadniczo V-VII w. - patrz Jażdżewski 1967, tabela 5). Wówczas to w granicach wymienionego regionu stwierdza się również zjawisko wyraźnego kryzysu cywilizacyjno -kulturowego o głębokich konsekwencjach polityczno-społecznych i gospodarczych, zaistniałe w związku z zerwaniem kontaktów obszaru z północnymi prowincjami Cesarstwa Rzymskiego. Doprowadziło ono m.in. do wzrostu rywalizacji i niepokojów między lokalnymi wodzami, którzy stali na czele zhierarchizowanych wspólnot.

${ }^{30}$ Najczęściej opisane relacje sprowadzały się do prawno-zwyczajowej formuły ,yrðdhi their felagar”. Służyła ona potwierdzeniu przyjaźni i partnerstwa, głównie między kupcami i wojownikami, którzy wspólnie finansując wyprawę, umawiali się co do podziału przyszłych zysków, w tym łupów (zob. Oddr Snorrason 1, s. 23). 
Siedzib wspomnianych wodzów archeologia upatruje w reliktach osiedli określanych naukowym terminem Zentralplätze lub Reichtumszentren, co oznacza (wielofunkcyjne) ośrodki centralne bądź ośrodki bogactwa (Fabech 1997; Müller-Wille 2003; Łosiński 2008, s. 127-128, tam m.in. polemika z niektórymi poglądami Müller-Willego). Dodajmy, iż tego rodzaje miejsca znane są też z ówczesnych źródeł pisanych jako Herrenhöfe, czyli dwory (rezydencje) arystokracji/władców, przykładowo „Heorot” opisany w staroangielskim poemacie heroicznym Beowulf (50-65, s. 33, 35), czy „Ad Gefrin” (Yeavering) anglosaskiego króla Northumbrii Edwina (616-633), wzmiankowany przez Bedę Wielebnego w Historiae Ecclesiasticae gentis Anglorum (Historia ludów Anglii, II.14, s. 150-152) 31. Były to ośrodki kultu, a zarazem etapowe punkty dalekosiężnej wymiany handlowej oraz miejsca zaawansowanego rzemiosła (głównie związanego z obróbką metali), stanowiące źródła luksusowych wyrobów dla lokalnych elit. Nierzadko ośrodki te funkcjonowały przez kilka stuleci, począwszy od młodszego okresu wpływów rzymskich aż po przełom środkowego i młodszego okresu wikińskiego (X/XI w.), kiedy to w większości uległy likwidacji decyzją ówczesnych monarchów (Christensen 1991; Hårdh 2000; Hårdh i Larsson [red.] 2002; Jørgensen 2005; 2009; Herrenhöfe... 2010; Clarke i Lamm 2017; Holst, Jørgensen i Wamers 2017). Szczególnie wyraźne ślady ich użytkowania pochodzą z okresu wędrówek ludów oraz z doby merowińskiej, tudzież z przełomu starszego i środkowego oraz środkowego okresu wikińskiego. Przede wszystkim były to jednak otoczone siecią osiedli wiejskich, nie zawsze z czytelną limitacją zasięgu, miejsca pobytu ówczesnych elit, z którymi nauka łączy określone znaki prestiżu, zarówno przedmioty, jak i obiekty monumentalne (Callmer 1997).

W literaturze obserwuje się w tym zakresie poważną zgodność poglądów. I tak, do grupy obiektów informujących o pozycji wspólnoty zalicza się wielkie kurhany ziemne lub ziemno-kamienne - obiekty wzniesione wysiłkiem kolektywnym, a także duże drewniane, zwykle długotrwałe i wielofazowe budynki halowe zbudowane w konstrukcji słupowej, które zawierały obszerną, centralnie umieszczoną salę recepcyjną, często oświetloną i ogrzaną paleniskiem (Evans 1989; Christensen 1991; Schmidt 1991; Van de Noort 1993; Duczko [red.] 1996; Duczko 1997; Ljungkvist 2008; Hope-Taylor 2009; Jørgensen 2009; Hamerow 2010, s. 281, ryc. 8; Ljungkvist, Frölund, Göthberg i Löwenborg 2011; Higham i Ryan 2013, s. 126 i n.).

Z kolei wśród mobilnych wyznaczników społecznego prestiżu uwzględnia się ekskluzywne grzebienie (!) oraz elementy uzbrojenia elitarnego, zwłaszcza ozdobne, segmentowe hełmy tzw. grzebieniaste (!) ze stylizowanym nosalem (są to wyroby jednostkowe, aczkolwiek podobne pod względem techno-stylistycznym), których ranga wynikała $\mathrm{z}$ akceptowanej społecznie symboliki włosów, w europejskim Barbaricum późnej starożytności i wczesnego średniowiecza postrzeganych

31 W przypadku królewskiej rezydencji w Yeavering dysponujemy też bardzo dobrym obrazem archeologicznym stanowiska (Hope-Taylor 2009; Hamerow 2010; Higham i Ryan 2013, s. 135 i n.). 
jako jeden z istotnych znaków społecznego prestiżu i władzy (Almgren 1980; Gansum 2003).

W literaturze przedmiotu sporo uwagi poświęcono poglądom podzielanym przez różne ludy niezależnie od miejsca, czasu oraz rozwoju cywilizacyjno-kulturowego, które we włosach, głównie głowy i twarzy, a także w paznokciach i zębach, upatrują elementy ciała ludzkiego o wyjątkowych konotacjach symbolicznych (por. Kopaliński 1990, s. 469-473, 490-492; Oesterreicher-Mollwo [red.] 1992, s. 177-178; P. Kowalski 1998, s. 428-432, 602-609, 619-624; Kempiński 2001, s. 466-467; Banek 2010, s. 25 i n.).

$\mathrm{W}$ tym przypadku wskazuje się - zwykle $\mathrm{z}$ odwołaniem do informacji zawartych w mitach lub legendach o stworzeniu Kosmosu i Człowieka - na okoliczność wyrastania zębów bezpośrednio z tkanki miękkiej, a włosów tudzież paznokci ze skóry, przy czym w charakterze semantycznych odpowiedników stawia się znak równości między wspomnianymi elementami ciała ludzkiego a wyrastającymi z ziemi roślinami, drzewami oraz górami (skałami). Tytułem przykładu odnotujmy, iż według mitologii skandynawskiej epoki wikingów „Z Ymira ${ }^{32}$ ciała ziemia jest stworzona, / A z krwi jego - morze, / Góry z kości jego, lasy z włosów [wyróżnienie - M.K.], / A z czaszki - niebo. / Z rzęs olbrzyma stworzyli bogowie / Midgard dla synów człowieczych, / A z mózgu jego złowrogie uczyniono / Chmury na niebie” (Edda poetycka, „Grimnismál” 40-41, s. 74).

Podkreśla się również fakt odrastania włosów i paznokci, co przypomina cykliczne odradzanie się świata roślin w przyrodzie. Z kolei poprzez fakt ścisłego zespolenia $\mathrm{z}$ ciałem, tudzież pełnionych wobec ciała funkcji ochronnych i estetycznych, włosy jak również paznokcie uznawane są powszechnie za substytut człowieka. W tym charakterze włosy przydatne są w rytualnych działaniach jednostki lub wspólnoty, zwłaszcza w obrzędach tzw. przejścia (np. połóg, śmierć, żałoba, postrzyżyny, bierzmowanie, śluby cywilne i zakonne) oraz w różnych nurtach magii (tu też paznokcie). W wielu społecznościach uważa się bowiem, iż włosy, jak też paznokcie stanowią źródło tajemniczej, pierwotnej mocy, która decyduje m.in. o ich „permanentnym” wzroście, fenomenie trwającym również po śmierci człowieka. Wspomnianą moc czerpią one (rzecz dotyczy przede wszystkim owłosienia głowy oraz twarzy) z faktu szczególnej podatności włosów na oddziaływanie sił nadprzyrodzonych, w tym demonów należących do świata chtonicznego.

32 Był to prapierwotny olbrzym-androgyn, który powstał w praotchłani (Ginnungagap) z wód topniejącego lodu. Żywił się mlekiem boskiej prakrowy-olbrzymki Audumli/Audumbli. Jego imię wywodzi się indoeuropejskiego "iem-, co oznacza „podwójny, dwojaki, bliźniak”. Został zabity przez trzech najstarszych bogów nordyjskiego panteonu, a zarazem braci - Odina, Wilego i We - którzy z krwi oraz ciała ofiary stworzyli prabudulec świata (Kempiński 2003, s. 233). 
W myśl tych poglądów, o charakterze niescjentystycznym, owłosienie głowy, swego rodzaju miraculum, stanowi naturalny, fizyczny łącznik człowieka ze światem transcendentnym, dzięki czemu ten ostatni może w zależności od rodzaju mocy, jakie przenikają w głąb ciała albo pozostają ukryte w kędziorach lub splotach włosów, pozytywnie bądź negatywnie wpływać na stan zdrowia, sił fizycznych, płodności, urody czy charyzmy ich właściciela lub właścicielki. W tym przypadku istotną rolę przypisuje się charakterowi owłosienia oraz sposobowi jego traktowania. Te relacje decydują z kolei o postrzeganiu włosów jako ważnego znaku społecznego, który w czytelny sposób pozwala waloryzować ich posiadacza, a w odpowiednich sytuacjach określać też relacje osoby ze sferą sacrum.

W kulturze symbolicznej różnych ludów nieuporządkowane owłosienie głowy oraz brody zwykle oznacza związek człowieka „z dzikością i chaosem Natury oraz świata podziemnego" (P. Kowalski 1998, s. 602). Fryzurę uznaje się natomiast za świadectwo podporządkowania się osoby normom kultury oraz przynależności do świata ładu opartego na porząadku boskim, czyli do ekumeny. Symptomatyczne, iż w wierzeniach skandynawskich doby wikińskiej stworzenie Buriego - praprzodka Asów, bo dziada Odina, Wilego i We - opisane zostało jako akt trójstopniowy, polegający na wyłanianiu się Buriego z bryły słonego lodu: najpierw jego włosów (!), następnie głowy, dopiero w trzecim etapie reszty ciała. Akt ów miał miejsce u początków czasu (Kempiński 2003, s. 50).

Dla wyników analizy grzebienia ze Stroszek istotne znaczenie może mieć fakt, iż opisane powyżej zjawiska obserwujemy w kulturze Germanów tak kontynentalnych, jak też północnych. Przypomnijmy, że wspomniany grzebień to najprawdopodobniej dzieło skandynawskiego rogownika, działającego w środkowym okresie wikińskim, które mimo unikatowej ornamentyki nie wykracza poza znane nam normy elitarnej kultury ówczesnych ludów germańskich.

Odnotujmy więc obecność, przynajmniej od późnej starożytności, silnie zakorzenionej wśród Germanów wiary w nadprzyrodzoną, magiczną moc długich, bujnych, ufryzowanych włosów, niekiedy splecionych bądź spiętych w pukiel (np. nodus Suebicus), przy czym szczególną atencją darzono włosy jasnego koloru złociste lub rude. Tego rodzaju włosy powszechnie uznawano za atrybut ludzi wolnych, społecznie wywyższonych, jednocześnie silnych, żywotnych i zdolnych do działania, zwłaszcza piastujących władzę królewską. Przypomnijmy, iż długie włosy arystokracji celtyckiej, jak również królów germańskich (reges criniti), $\mathrm{u}$ tych ostatnich potwierdzone nie tylko w państwie Merowingów, lecz również w Skandynawii okresu wikińskiego (vide zmarły w roku 933 Harald Pięknowłosy), miały być uświęcone magiczną emanacją sił boskich (por. Lapis 1986, s. 12-13; Markale 1988, s. 76; Banek 2010, s. 27-29, 79; Kasperski 2017b, s. 165 i n.). $\mathrm{Z}$ tego też względu odgrywały one istotną rolę w sakralizacji politycznej władzy zwierzchniej, a ich posiadanie stanowiło warunek sine qua non udziału w rytaulno-prawnych mechanizmach dziedziczenia władzy. Z kolei przymusowe ścięcie włosów uznawane było za okoliczność hańbiącą zarówno wolnego mężczyznę, jak 
i kobietę. Uważano bowiem, iż nienaturalna utrata włosów, pozbawiając osobę - na zasadzie pars pro toto - właściwych jej mocy sakralnych lub magicznych, obezwładniała tudzież prowadziła do zaniku dotychczasowej tożsamości, w tym królewskiej charyzmy. Wspomniane zjawisko obowiązywać miało również w świecie bogów, o czym informują dzieje północnogermańskiej bogini Sif, której podstępem ścięto piękne, złote włosy, co było równoznaczne $\mathrm{z}$ utratą przez boginię funkcji nadprzyrodzonych. Prawdopodobnie odpowiadała ona za sferę płodności, może za obfite plony zbóż, przy czym tej ostatniej atrybucji badacze nie podzielają powszechnie (Kempiński 2001, s. 389; 2003, s. 181-182; Słupecki 2003, s. 278-280; w cytowanych pracach dalsza literatura). Przywrócenie pierwotnego statusu bogini zapewniła jej magiczna replika włosów (dzieło karłów), które przytwierdzone do głowy bogini, rosły odtąd jak naturalne.

W systemach społeczno-kulturowych ludów germańskich późnej starożytności i wczesnego średniowiecza włosy (także porastające brodę) pełniły zatem funkcję wysoce prestiżowego znaku, który w czytelny sposób informował o pozycji społecznej właściciela (co najmniej człowiek wolny i dojrzały) oraz o jego szczególnych relacjach ze światem, postrzeganym w kategorii kosmosu ${ }^{33}$. W tych relacjach istotne znaczenie miała imitacja mityczno-sakralnych wzorców jako odniesień kluczowych dla obowiązującego systemu wartości. Dokonywano jej zarówno w wymiarze społecznym, jak i w wymiarze jednostki.

W pierwszym przypadku z rzeczonych wzorców korzystano przy zakładaniu wspomnianych powyżej, wielofunkcyjnych miejsc tzw. centralnych, które fundowano z uwzględnieniem przesłanek symbolicznych, przez co wspomniane miejsca stawały się ośrodkami mikrokosmosu lokalnej wspólnoty lub grupy wspólnot (Larsson 2015). Przypuszcza się nawet, wskazując na pochodzący z przełomu starożytności i średniowiecza, dobrze rozpoznany archeologicznie ośrodek w Gudme na duńskiej wyspie Fionia (Nielsen, Randsborg i Thrane [red.] 1993; Jørgensen 2009; Grimm i Pesch [red.] 2011), iż część miejsc centralnych stanowić mogło w zakresie modelu funkcjonalno-przestrzennego naśladownictwo mitycznego Asgardu nordyjskich bogów - „Grodu Asów”, którego opis utrwalony został w mitologii skandynawskiej epoki wikińskiej (Hedeager 2001; 2002; Jørgensen 2009, s. 332).

${ }^{33}$ Warto odwołać się w tym miejscu do informacji Tacyta (schyłek I w. n.e.), iż germańscy Chattowie ,[...] gdy tylko dorosną, zapuszczają włosy i brodę, i póki nie zabiją wroga, nie pozbywają się tego wyglądu twarzy, który ślubem zaprzysięgli męstwu" (Germania 31, s. 85). W innym dziele (początek II w. n.e.) Tacyt nadmienia, że wódz plemienia Batawów, „Cywilis, który - wedle zwyczajnego barbarzyńcom ślubu - po wszczęciu z Rzymianami wojny [69-70 r. n.e. - dop. M.K.] długie swe włosy na dół zaczesywał i na rudo barwił, ściął je dopiero po dokonaniu rzezi legionów [...]" (Dzieje IV.61-62, s. 564). Podobny czyn przypisuje się panującemu w okresie wikińskim (około 870-930) królowi norweskiemu Haraldowi Pięknowłosemu, który wywodził się z mitycznej dynastii Ynglingów, biorącej początek ze szwedzkiej Uppsali. W uroczystej przysiędze zobowiązał się nie strzyc włosów ani ich nie czesać do momentu ustalenia swego jedynowładztwa w Norwegii. Informuje o tym w „Sadze o Haraldzie Pięknowłosym" staronordycka księga królów norweskich, zatytułowana Heimskringla (Kula ziemska), którą w 1. połowie XIII w. spisał na Islandii poeta i historyk Snorri Sturluson, autor cytowanej przez nas Eddy Młodszej/Prozaicznej (por. Adamus 1970, s. 239). 
Koncepcja nie jest podzielana powszechnie (Sundqvist 2011); teza o symboliczno-kosmicznej waloryzacji tego rodzaju ośrodków władzy, kultu, handlu i elitarnego rzemiosła nie została jednak podważona.

Z kolei w wymiarze jednostki udział wzorców mityczno-sakralnych przejawiał się w doborze kryteriów urody i stroju, zjawisku czytelnym zwłaszcza wśród elit (Vierck 1978), co w przypadku Germanów północnych wynikało z przekonania o podobieństwie pierwszej pary ludzi - Aska i Embli - do bogów (Kempiński 2003, s. 30-31; Słupecki 2003, s. 37-41).

Próbując określić podzielane przez Normanów kryteria urody, przypomnijmy złote włosy nordyckiej bogini Sif, które według mitologicznych przekazów miały być niezwykle piękne, m.in. z racji koloru. Odnotujmy też symptomatyczne przydomki boga Odina, przywódcy nordyckiego panteonu, z tego tytułu szczególnie czczonego przez skandynawskich wodzów oraz władców, pana poległych wojowników i suwerena wyroków, które brzmiały Langbarðr („Długobrody”), Hárbarðr („Siwobrody”) lub Hrosshársgrani („O Brodzie z Końskiego Włosia”/,Z Brodą o Końskich Włosach”) (Kempiński 2003, s. 165; Simek 2003, s. 137 i n.). Dodajmy, iż wzmiankowany już przez nas, podobnie jak Odin, nordycki bóg Thor odpowiednik starogermańskiego Donara i staroanglosaskiego Thunora, piorunowładca, jeden z najpotężniejszych w boskiej rodzinie Asów, z racji ogromnej siły fizycznej oraz ochoty do walki czczony zwłaszcza przez szeregowych wojowników, również przez żeglarzy i kupców (wikingów) - opisywany był jako mężczyzna ,wielkiego wzrostu i miłego wyglądu, z rudym zarostem" oraz rudymi włosami, które w chwilach szału stawały mu na sztorc (Słupecki 2003, s. 50, 129-158, cytat s. 132; zob. też Oddr Snorrason 59, s. 125; Krantz 1972, s. 111 i n.; Simek 2003, s. 130 i n.).

Pozostając w dotychczasowym nurcie rozważań, wskażmy też na gest dotykania brody rękoma lub ręką, który mógł - naszym zdaniem - towarzyszyć uroczystej, sakralnej przysiędze składanej przez Skandynawów podczas zawierania przymierza, pobratymstwa i/lub dobijania targu. Istnienie tego rodzaju zwyczaju w kulturze skandynawskiej i ruskiej X-XI w. sugerują stwierdzone na terenie Islandii, Skandynawii oraz Ukrainy ( $\mathrm{w}$ tym ostatnim przypadku w ewidentnej łączności z kulturą Rusów) znaleziska niewielkich figurek wczesnośredniowiecznych z brązu, bursztynu, kła lub kości morsa, które przedstawiają mężczyznę siedzącego zwykle na podkurczonych nogach, sporadycznie na ozdobnym krześle (zapewne tronie por. Hauck 1984), nadto z długą, spiczastą brodą, może zaplecioną w warkocz bądź warkocze, trzymaną w dłoni lub dłoniach (Jansson 1992; Lyngstrøm 1992; Muraseva 1992; Vilhjálmsson 1992; Wahlöö 1992; Helmbrecht 2011, s.138-139). Gest ów nasuwa skojarzenie $\mathrm{z}$ magiczno-sakralnym zwyczajem zaklinania przysięgi na brodę przez wolnych mężczyzn (chodzi o swego rodzaju poręczenie), który do chwili obecnej praktykowany jest w świecie muzułmańskim (Kopaliński 1990, s. 31). Dodajmy, że również pozycja siedząca na podkurczonych, podwiniętych lub skrzyżowanych nogach wydaje się zapożyczeniem z elitarnej kultury nomadów, 
aczkolwiek potwierdzona jest także u starożytnych Celtów, w tamtejszej figuralnej plastyce sakralnej, jak również u wyznających buddyzm ludów Indii oraz Dalekiego Wschodu, gdzie praktykowana jest na wzór medytacji Buddy przez joginów. We wszystkich wspomnianych przypadkach wyraża ona świętość, opanowanie, bogactwo i wyniosłość wynikającą z prestiżu oraz uczestnictwa w szczególnie podniosłym rytuale (Jakimowicz 1967, s. 102-103; Schlette 1987, s. 131) ${ }^{34}$.

Figurki skandynawskie interpretuje się najczęściej jako wizerunki nordyckich bogów (np. Freya lub Thora, chociaż w grę wchodzić może też Odin lub Tyr zob. Lamm 1981; Jansson 1992; Murasheva 2007, s. 98; Helmbrecht 2011, s. 139-140). Według innych domysłów przynajmniej niektóre służyć mogły jako „piony” używane w ówczesnych grach planszowych (zagadnienie to rozważa Perkins 2001, s. 135 i n.). Ta ostatnia atrybucja nie koliduje z konotacją symboliczną wspomnianych przedmiotów, zważywszy na magiczno-sakralny charakter (losowych) gier planszowych typu hneftafl w kulturze Skandynawów doby wikińskiej, wynikający z ich sakralnej genezy (chodzi o złote tablice nordyckich bogów gullnar toflur, które pozwalały rządzić przeznaczeniem; zob. Kempiński 2003, s. 236-237; Słupecki 2003, s. 42). Oczywiście gry typu hneftafl służyły też elitarnej rozrywce.

Potwierdzony źródłowo fenomen włosów w germańskich systemach społeczno -kulturowych późnej starożytności i wczesnego średniowiecza nie wynikał jedynie z faktu posiadania przez kobietę lub mężczyznę określonego owłosienia. Istotny był również sposób traktowania wspomnianych włosów, wynikający z wiary (podzielanej nie tylko przez ludy germańskie) w obecność magicznych lub quasi-magicznych mocy we włosach, zwłaszcza porastających głowę. Owe tajemnicze moce, determinujące człowieka, usiłowano kontrolować za pomocą różnorodnych praktyk, których celem było umiejętne podtrzymanie żywotności włosów, jako warunku kumulacji w ciele kobiety lub mężczyzny (przede wszystkim w głowie i piersi) nadprzyrodzonych sił, które decydowały o spiritus movens osoby ${ }^{35}$. Najprawdopo-

${ }^{34} \mathrm{~W}$ tym kontekście warto przypomnieć o istnieniu intensywnych kontaktów, głównie gospodarczych, ludów skandynawskich z Orientem w VIII-X w. (Łosiński 1988; 1993), jak również o niewielkim brązowym posążku Buddy wykonanym w Indiach w VI w. n.e., odkrytym w reliktach wczesnośredniowiecznego ośrodka typu Zentralplatz lub Reichtumszentrum w Helgö koło Birki (Szwecja, Uppland). Badacze łączą znalezisko z pozostałościami osiedla datowanymi bądź na okres Vendel (VI-VIII w.), bądź na starsze stadium okresu wikińskiego (stulecie IX), aczkolwiek nie wyklucza się ewentualności, że statuetka używana była przez ludność Helgö zarówno w okresie Vendel, jak i w starszym okresie wikińskim. Zob. Androshchuk 2007; Jørgensen 2009, s. 334-335; Clarke, Lamm 2017, według indeksu (hasło: Buddha).

${ }^{35}$ O tym, że wczesnośredniowieczni Skandynawowie postrzegali wspomniane elementy ciała ludzkiego jako „pojemniki” życiodajnej mocy, możemy domyślać się z przekazów mitologii nordyckiej, opisujących moment powstania pierwszej pary ludzi - Aska i Embli. Według Eddy poetyckiej („Völuspá” 17-18, w thumaczeniu L.P. Słupeckiego) bogowie Odin, Hönir i Lodurr/Lodur ożywili wspomnianą parę na swoje podobieństwo, dając im ducha, rozum oraz ciepło (Słupecki 2003, s. 37; zob. też Kempiński 2003, s. 30). Duch - boskie tchnienie wyrażone przez przebywającą w ciele duszę oraz oddech - przeniknął w głąb ciała zapewne przez nozdrza lub usta człowieka, czyli poprzez głowę. Również w głowie bogowie ulokowali rozum, natomiast oddech oraz tętniące krwią (życiem) 
dobniej służyły temu cykliczne zabiegi z użyciem określonych przyborów tzw. toaletowych (m.in. grzebieni), które w przypadku owłosienia sprowadzały się do czesania, fryzownia, zaplatania, przycinania, depilacji, barwienia czy mycia. Dodajmy, że czesanie włosów było równoznaczne z oczyszczaniem głowy i/lub brody z insektów. Świadczą o tym potwierdzone w znaleziskach archeologicznych przypadki grzebieni z zasuszonymi wszami ludzkimi, które tkwiły między zębami grzebienia (Rijkelijkhuizen 2011, s. 202).

Dla naszych rozważań kluczowe znaczenie ma spisana przez Ahmada ibn Faḍlāna Księga (Kitāb) - etnograficzno-historyczne dzieło arabskie z wczesnego średniowiecza. Jest to relacja $\mathrm{z}$ odbytej w latach 921-922 n.e. podróży poselstwa kalifa abbasydzkiego do króla Bułgarów kamskich (nadwołżańskich) Almiša, w której autor dzieła uczestniczył jako dyplomata (Kmietowicz, Kmietowicz i Lewicki 1985, s. 7 i n.). Wyraźnie informuje ona o istnieniu w kulturze wczesnośredniowiecznych ludów północnej i wschodniej części Barbaricum europejskiego funkcjonalnych związków między wzmiankowanymi powyżej zabiegami higienicznymi, w tym czesaniem włosów grzebieniem, a magią apotropaiczną. Księga zawiera m.in. szczegółowy i wiarygodny opis przedstawicieli zbrojnych nobilów ludu ar-Rūsīja/ar-Rūs (czyli Rusów, należących do gens Sueonum - zob. Duczko 2006, s. 21 i n.), którzy w celach handlowych przybyli na dużych łodziach (statkach) rzeką Wołgą do głównego miejsca targowego Bułgarów kamskich, które znajdowało się w okolicy późniejszego grodu Bulgar. Dodajmy, że z Rusami zetknął się tam Ibn Faḍlān osobiście. W sposób typowy dla uczonego Araba (prawdopodobnie był nawróconym na islam Grekiem) odnotował m.in. zwyczaje Rusów odmienne od cywilizacyjno-kulturowych norm obowiązujących w kalifacie (Kmietowicz, Kmietowicz i Lewicki 1985, s. 117, 192 i n.).

\footnotetext{
serce w piersiach. Być może z klatką piersiową łączyli Skandynawowie także ciepło ludzkiego ciała - kolejny dar bogów, powiązany $z$ krążącą krwią i zdrowym rumieńcem twarzy. W tym przypadku warto wskazać na podobieństwo łączące płuca z miechami kowalskimi.

${ }^{P}$ rzekonanie o mediacyjnej roli głowy, zwłaszcza oczu oraz ust, jako swego rodzaju bramy, pozwalającej wniknąć siłom dobra lub zła w głąb ludzkiego ciała, nie ograniczało się do ludów germańskich, lecz miało zasięg szerszy i ponadczasowy. Pogląd ów podzielał m.in. wczesnośredniowieczny Kościół Rzymski. Zob. S. Rosik (2007), gdzie interesujące uwagi na ten temat, w związku z analizą wydarzeń towarzyszących abrenuntiatio diaboli z terenu słowiańskiego grodu w Chockowie (obecnie Gützkow w Meklemburgii, Niemcy) w roku 1128, opisanych w Żywocie św. Ottona biskupa bamberskiego (Ebo III, 10-11). Rzecz dotyczy ogromnego roju much, które wypadły ze świątyń miejscowych bożków i dokuczliwie zaatakowały oczy oraz usta (!) zgromadzonego ludu - świadka wydarzeń próbując $\mathrm{w}$ ten sposób dokonać zemsty na niewiernych wyznawcach lub ich opętać. Z przekazu wynika jednoznacznie, iż według Ebona, pod postacią obrzydliwych owadów ukryły się demony wypędzone ze swych dotychczasowych siedzib mocą chrześcijańskiego Boga.
} 
I tak, po osiągnięciu targowiska, Rusowie cumowali łodzie na brzegu Wołgi, a następnie wznosili $\mathrm{w}$ pobliżu przystani wielkie, drewniane domy wyposażone w ławy ${ }^{36}$, gdzie podzieleni na dziesięcio- lub dwudziestoosobowe grupy mieszkali na czas trwania targu wraz z młodymi, urodziwymi niewolnicami przeznaczonymi na handel (być może każda załoga statku dysponowała własnym domostwem). $\mathrm{Z}$ zainteresowaniem godnym bogobojnego muzułmanina, skrupulatnie przestrzegającego religijnego nakazu ablucji, Ibn Faḍlān odnotował w swej relacji, iż w wymienionych domach „Każdego dnia, nieodzownie, myją oni (Rusowie - dop. M.K.) swe twarze i głowy w najbardziej plugawej i nieczystej wodzie, jaka istnieje. A [odbywa się] to tak, że każdego dnia rano przychodzi niewolnica [niosąc] ze sobą wielką misę z wodą (wyróżnienie - M.K.) i wręcza ją swemu panu. [Ten] myje w niej ręce, twarz i włosy na głowie. On je (tj. włosy) myje, czesze grzebieniem do tej miski (wyróżnienie - M.K.), potem czyści nos i spluwa do niej i wszystkie rezultaty swych plugawych czynności pozostawia w tej wodzie. A kiedy zakończy to, czego potrzebował, dziewczyna zanosi miskę do tego, który [siedzi] obok niego. I ten czyni podobnie, jak to robił jej pan, a ona nie przestaje nosić jej (tj. miski) od jednego do drugiego, aż obniesie ją wokoło do wszystkich, którzy są w tym domu, a każdy z nich smarka i pluje i myje w niej swoją twarz i włosy" (Ibn Faḍlān, rozdz. [210b], s. 110).

W literaturze przedmiotu przytoczony opis traktuje się zwykle jako źródło $\mathrm{z}$ epoki, informujące o stanie praktyk higienicznych Rusów w 1. połowie X w. (np. K. Ambrosiani 1981, s. 13). Nie negując tych ustaleń, uważamy jednak, iż relację Ibn Faḍlāna można przeanalizować też pod nieco innym kątem poznawczym.

W opisanej ablucji dopatrujemy się bowiem zbiorowego obrzędu magicznego, który w tej samej formie praktykowany był przez wspólnotę Rusów każdego poranka, przynajmniej w okresie ich pobytu na terytorium Bułgarów kamskich, czyli w sytuacji wielorakiego zagrożenia, jakie niosły ze sobą kontakty z obcym ludem oraz ich bóstwami ${ }^{37}$. Za zespołem praktyk rytualnych przemawia cykliczność oraz rytmika gestów towarzyszących oczyszczeniu rąk, twarzy, włosów głowy, ust (?)

${ }^{36}$ Chodzi zapewne o cieszące się społecznym mirem (Jørgensen 2009) obszerne budynki tzw. halowe lub w typie hal $-\mathrm{z}$ wielofunkcyjnymi ławami wzdłuż wewnętrznych krawędzi ścian - znane m.in. z datowanych około przełomu IX i X w. odkryć archeologicznych z obszaru Rusi Północnej. W przeciwieństwie do budynków wzmiankowanych przez Ibn Faḍlāna, gdzie należy domyślać się konstrukcji doraźnych, były to obiekty bardzo solidne. Badacze łączą je z elitarnymi ugrupowaniami kupców-wojowników. Zob. odsłonięte w Starej Ładodze drewniane relikty przyziemia tzw. dużego domu (,,bol`šoj dom”), interpretowanego jak wyżej, który ujawnił luksusowe przedmioty, m.in. grzebień, miniaturowy żelazny toporek o funkcji kultowej (emblemat Thora lub Peruna?), odważniki wagowe, „kamienie” do gry, w tym figurę zwaną królem - Černych 1985, s. 76, 79-80 („,bol“šoj dom”); Rjabinin 1985, s. 39 i n., ryc. 11; Rjabinin i Černych 1988, s. 91-93, 98, ryc. 8.

37 Zauważmy, że w sporządzonej przez Ibn Faḍlāna relacji o napotkanych nad Wołgą Rusów, zaraz po opisie porannej ablucji członków grupy, znalazła się obszerna informacja o ich praktykach religijnych. Dotyczy ona obrzędów, jakich Rusowie dokonywali bezpośrednio po wkroczeniu na ziemię Bułgarów (Ibn Faḍlān, rozdz. [210b], s. 110). Istotą wspomnianych praktyk były modlitwy zanoszone 
oraz nosa przez dokonujących ablucję, kategoryczny charakter ich działań, szczególny wybór miejsca oraz czasu podejmowanych czynności (wnętrze hali o poran$\mathrm{ku}$ ), wreszcie obecność ściśle określonej grupy, składającej się z osób obojga płci o sprecyzowanych zadaniach, wieku, statusie społeczno-prawnym, a nawet urodzie. Przypomnijmy, że byli to dorodni, zbrojni uczestnicy dalekosiężnej wyprawy handlowej $^{38}$, jednocześnie żeglarze, ludzie wolni, którzy w grupie liczącej około 10-20 osób wypełniali wnętrze hali, zajmując najprawdopodobniej ławy ulokowane wzdłuż ścian budynku. Uczestnicy ablucji tworzyli zatem figurę geometryczną przypominającą okrąg, który w kulturach różnych ludów, wraz z ,pokrewnym” mu kołem, posiada wyraźne odniesienia symboliczno-magiczne.

W tym przypadku na szczególną uwagę zasługują ustalenia antropologii kulturowej, które rytualny ruch obrotowy oraz powiązane z nim antropogeniczne figury koła lub okręgu wpisują w logikę mityczno-symbolicznego obrzędu przejścia, typową dla społeczności o myśleniu tradycyjnym („nieoswojonym”). Służy on osiągnięciu określonej zmiany, umożliwiając jednostce lub wspólnocie zamknięcie sytuacji, poprzez jej rytualne uśmiercenie, oraz otwarcie nowego stanu, poprzez odrodzenie kolejnej sytuacji na kole „Historii”. W związku z tym obrzęd przejścia zawiesza Czas na okres swego trwania, a w określonych sytuacjach, wyrażonych inwersją ruchu obrotowego, cofa nawet jego bieg w wymiarze symbolicznym, zwracając uczestników obrzędu ku Przodkom, czyli w Przeszłość. Wspomniane obrzędy wpisują się w mit „wiecznego powrotu” (por. Eliade 1998), aczkolwiek nie zawsze muszą wiernie odzwierciedlać jego ideę. W określonych sytuacjach pozwalają jednak zbliżyć się do świata sacrum, czyli do sfery jednolitej, transcendentnej, logicznie uporządkowanej, statycznej - odpornej na upływ czasu i skażenie, odznaczającej się powszechnym pokojem, dobrobytem, sprawiedliwością i brakiem uciążliwej pracy. Służą temu, odtwarzane rytualnie w obrzędzie przejścia, kulturowe warunki pozwalające zaistnieć sytuacji wzorcowej, którą powszechnie uznaje się za typową dla „rajsko-sakralnych” początków świata. Dla członków wspólnoty jest to archetyp organizujący społeczność (na ten temat Wasilewski 1978; 1987; P. Kowalski 1998, s. 231-234, 461; Kempiński 2003, s. 237 [hasło: „Złoty wiek”]; w tych pracach dalsza literatura).

W opisanym przez Ibn Faḍlāna zgromadzeniu Rusów uczestniczyła też młoda kobieta; była to niewolnica należąca prawdopodobnie do właściciela statku, a zarazem gospodarza hali. Usługiwała ona mężczyznom, podając każdemu, według

przez Rusów do wizerunków własnych bóstw, w celu wyjednania ich opieki w transakcjach handlowych z obcymi kontrahentami.

W nawiązaniu do informacji Ibn Faḍlāna o dokonywanej każdego poranka ablucji Rusów, połączonej z czesaniem włosów, odnotujmy wzmiankę z XIII-wiecznej kroniki Jana z Wallingford. Tamże, w odnoszącym się do początku XI stulecia opisie Duńczyków, zamieszkujących Anglię w czasach panowania Ethelreda II Gnuśnego (978-1016), stwierdzono, iż czeszą oni włosy każdego dnia, biorą kąpiel w każdą sobotę i często zmieniają odzież (za: K. Ambrosiani 1981, s. 13).

38 Wzmiankuje o tym Ibn Faḍlān (rozdz. [210a], s. 109) w charakterystyce Rusów, która poprzedza opis ablucji. 
określonego porządku, misę z wodą. Przypomnijmy, iż w analizowanych praktykach oczyszczających istotną rolę odgrywały: osobisty grzebień każdego z mężczyzn oraz wspomniana misa, zapewne własność przywódcy grupy, wypełniona od momentu rozpoczęcia obrzędu ciągle tą samą wodą ${ }^{39}$. Było to naczynie przechodnie, które krążąc rytualnie między uczestnikami zgromadzenia, wytwarzało wśród nich poczucie wspólnoty. Podobne zjawisko potwierdzają źródła pisane w odniesieniu do biesiad skandynawskich elit wczesnośredniowiecznych, podczas których wypełniony piwem lub miodem puchar (albo róg) krążył między ucztującymi w hali wojownikami ${ }^{40}$.

Wydaje się, iż w opisanym obrzędzie ablucji wypełniona wodą misa tworzyła z grzebieniem zespół funkcjonalny. W tym układzie misa, ze względu na konotacje $\mathrm{z}$ wodą oraz kierunkiem dolnym, wydaje się mieć relacje $\mathrm{z}$ tzw. sferą chtoniczną. Z kolei grzebień - wskutek ewidentnych relacji z głową, najwyżej ulokowaną częścią ciała ludzkiego - zdaje się ujawniać związki ze sferą niebiańską (uraniczną). Za tak sformułowaną hipotezą przemawia też połyskliwość oraz kolor poroża jeleniowatych, konkretnie twardej kompakty znajdującej się pod korą wieńca jelenia lub łopaty łosia czy renifera, z której wykonywano grzebienie używane w wczesnym średniowieczu w Europie Północnej i Środkowo-Wschodniej (zob. Cnotliwy 1973; Ulbricht 1978; Smirnova 2005). Jest on zwykle tożsamy z odcieniami jasnego (ciepłego) brązu lub jasnej żółci, które w zakresie semiotyczno-symbolicznym nasuwają skojarzenia ze słońcem ewentualnie ogniem (por. Libera 1987, zwłaszcza s. 126 i n.; Kopaliński 1990, s. 126-127; Kowalska 1998, s. 47 i n.; P. Kowalski 1998, s. 223-224, 227-229). Dodajmy, iż wykonywane grzebieniem podczas czesania włosów cykliczne ruchy o kierunku „góra - dół - góra”, w układzie symbolicznym mogły odzwierciedlać tradycyjne przekonania ówczesnych ludzi o konieczności konstytuowania ładu ekumeny (także w wymiarze mikrokosmosu) na podstawie zasad mitu „wiecznego powrotu”, czyli do początków

${ }^{39}$ W relacji Ahmada Ibn Faḍlāna wymieniony został tylko jeden grzebień, którego właściciel (inicjujący obrzęd mężczyzna) używał do czesania swych włosów bezpośrednio po ich umyciu. Pod koniec relacji Ibn Faḍlān nadmienił jednak, że również pozostali uczestnicy ablucji postępowali podobnie. Na tej podstawie sądzimy, iż wzorem przywódcy także oni czesali swe włosy. Nie można jednak wykluczyć, że grzebieniem posługiwał się tylko gospodarz hali, a pozostali członkowie zgromadzenia nie czesali włosów względnie gładzili mokre włosy rękoma. Obie sytuacje, zważywszy na istotę ablucji opisanej przez Ibn Faḍlāna (oczyszczenie ważnych dla człowieka części ciała z brudu i insektów), uważamy jednak za mało prawdopodobne.

${ }^{40} \mathrm{Nie}$ jest to jedyna analogia z ucztą książęcą lub królewską, która we wczesnym średniowieczu europejskim, jak również w starożytności, miała głęboki sens społeczno-symboliczny, a ze względu na obecność w zespołach sakralno-pałacowych lub budynkach halowych z ulokowanym pośrodku paleniskiem - także konotacje z sacrum (Kempiński 2001, s. 322). W analizowanym obrzędzie ablucji misę z wodą podawała mężczyznom młoda kobieta. Także w biesiadach uczestniczyły niewiasty, które m.in. rozlewały trunki względnie (jak walkirie w Walhalli) usługiwały ucztującym mężczyznom, podając im naczynie lub naczynia z alkoholem (Kempiński 2003, s. 220-221; Słupecki 2003, s. 246; Holst, Jørgensen, Wamers 2017, s. 96 i n.). 
nieskażonych złem (na ten temat P. Kowalski 1998, s. 149 [Granica i centrum], 503 [Wyprawy w dót rzeki]; Toporow 2003, s. 59 i n.).

Sytuacja nasuwa skojarzenie ze starożytnym, asyryjskim obrzędem oczyszczenia (kataraktycznym), wykorzystującym moce magii ochronnej, który stosowany był również przez Hetytów. Nakazywał on królowi w sytuacji zagrożenia zdrowia starannie zgolić włosy na całym ciele, a następnie zamknąć je w opieczętowanym naczyniu, które należało pozostawić na granicy wrogiego kraju, czyli poza własną ekumeną. Tam winny one szkodzić nieprzyjaciołom, ponieważ żywiono przekonanie o ukrytej we włosach magicznej nieczystości - źródle choroby. W ramach rytuałów substytucyjnych, służących ochronie króla przed wywróżonym mu złem, odłączone od ciała włosy i/lub paznokcie, naznaczone zmazą, można było wrzucić też - jako substytuty monarchy - do rzeki (wykluczone zostały źródła!), aby uwięzione w bieżącej wodzie wraz ze złem jak najdalej odpłynęły od króla. Hetyci praktykowali również wyczesywanie magicznych nieczystości grzebieniem podczas obrzędów leczniczych, w których nawiązywano do kosmologicznego mitu ,rajskiego początku", przywołując pozytywne rezultaty czesania owiec przez Słońce i boginięczarodziejkę tudzież uzdrowicielkę Kamrusepę (Popko 1982, s. 52 i n., 68). Z tych samych powodów włosy usuwali też Sumerowie, uważając, iż zabieg ów skutecznie zabezpieczy ich przed szkodliwym działaniem złych duchów. Ponieważ te przypominać miały dym, mogły zatem łatwo ukryć się we włosach (Cirlot 2007, s. 455).

W opisanych sytuacjach nieczystość nie była definiowana w sensie biologicznym, lecz stanowiła zjawisko motywowane logicznie, jako fenomen o niejasnym statusie. W mentalności ludów tzw. tradycyjnych brak czystości skutkuje bowiem brakiem porządku, który naruszał harmonię pierwotnego ładu sakralnego zarówno w wymiarze jednostki, jak i wspólnoty. W tym przypadku mamy do czynienia ze znanymi antropologii zjawiskami kulturowej rozłączności oraz integralności, określanymi mianem zasad, które wpisują się w podstawy pojęcia religijnej zmazy. Są one wzajemnie powiązane. I tak, zasada rozdziału ma na celu skuteczne usunięcie tabuizowanej nieczystości, w związku z przekonaniem, iż wszystkie istoty żywe (dotyczy zwłaszcza człowieka) winny odzwierciedlać formę nieuszkodzoną, czyli zgodną z wizją sił sakralnych, objawioną w ,arkadyjskim” modelu świata. Z kolei zjawisko integralności tożsame jest z próbą osiągnięcia przez jednostkę lub wspólnotę - uczestniczącą w rytualnym obrzędzie oczyszczenia - sytuacji zbliżonej do wzorca pierwotnego ładu sakralnego. Polega ona na integracji człowieka oraz istot żywych z sacrum, w celu uzyskania pomyślnego losu oraz zabezpieczenia się przed skutkami działania demonicznych mocy pochodzenia chtonicznego (na ten temat Wasilewski 1987, tamże dalsza literatura, zwłaszcza ważne dla problematyki prace M. Douglas, E. Leacha, V. Turnera).

Wydaje się, iż wiarę w istnienie groźnych demonów - istot nadprzyrodzonych tkwiących bądź we włosach, bądź w ludzkim ciele, i wywołujących m.in. przenośne choroby - powiązaną z przekonaniem o działaniu określonych praktyk magii oczyszczającej, jako skutecznego antidotum na wpływy groźnych mocy chtonicz- 
nych, podzielali również wczesnośredniowieczni Germanie i Rusowie. Odnotujmy, iż według spisanej w 2. połowie XII w. duńskiej Chronicon Lethtrense (VI, s. 51; polskie thumaczenie dzieła zob. Kronika królów z Lejre) legendarny król Snyo (Śniegu) - władca okrutny, pyszny, ponad miarę złośliwy, dumny i niesprawiedliwy - zmarł zgodnie z przepowiednią olbrzyma Lae (była to swego rodzaju wywróżona klątwa) pogryziony przez wszy. Kronikarz stwierdził, iż „Wyszły [one - dop. M.K.] z nosa i uszu jego i całe ciało pokryły" (za Kronika królów z Lejre 6, s. 27-28) ${ }^{41}$. O złych duchach przepoczwarzonych w muchy - chorobotwórcze owady budzące niepokój i wstręt, o czym w odniesieniu do słowiańskiego Chockowa, wzmiankowaliśmy powyżej - informuje z kolei Historia Longobardów Pawła Diakona (VI.6, s. 309-310), relacjonując spotkanie króla Kunikperta Pobożnego (panował w latach 688-700) ze złym duchem, który zgodnie z chrześcijańską wymową dzieła utożsamiony został $\mathrm{z}$ diabłem. Może dlatego opisani przez Ibn Faḍlāna Rusowie, podobnie jak starożytni Hetyci i Asyryjczycy, nie usuwali do źródlanej wody brudu z rąk, twarzy oraz włosów, jak również wydzielin z nosa oraz ust (?), a być może też wyczesywanych wszy, lecz skrupulatnie gromadzili je w naczyniu. $Z$ treści asyryjskiego przekazu wynika jednoznacznie, iż niezależnie od uwarunkowań utylitarnych, użycie pojemnika w rycie oczyszczenia determinowały czynniki symboliczne, czytelne również $\mathrm{w}$ opisie przyczyny śmierci duńskiego króla Snyo.

Konotacji symbolicznych należy domyślać się także w przypadku misy użytej w obrzędzie ablucji Rusów. Przypomnijmy, iż wspomnianą misę, naczynie dużych rozmiarów, wypełniono wodą, która wskutek kontaktu z brudem usuwanym z ludzkiego ciała oraz porastających głowę włosów zmieniała swój charakter, przeistaczając się - jak trafnie zauważył Ibn Faḍlān - z substancji naturalnie czystej w wyjątkowo plugawą i nieczystą. (Skażeniu wskutek kontaktu $\mathrm{z}$,,chorobotwórczymi” włosami króla uległo też naczynie użyte w obrzędzie asyryjskim; zyskało ono złe moce, w związku z czym, jako niebezpieczne w kontakcie, musiało zostać opieczętowane.). W sensie symbolicznym wypełniona wodą misa wyobrażała najprawdopodobniej zbiornik wodny, w którym topiono nie tyle usuwane $\mathrm{w}$ trakcie ablucji wydzieliny, brud oraz robactwo, ile ukryte w nich demony względnie substytuty wspomnianych demonów w postaci wytworzonego przez nie brudu, wydzielin oraz insektów. Do misy z wodą mogły trafić też przypadkowo wyczesane włosy, które w myśl przekonań ludzi średniowiecza stanowiły wraz z paznokciami substytuty człowieka o istotnym znaczeniu dla jego egzystencji, zwłaszcza dla zdrowia oraz życia. Uważano bowiem, iż odcięte włosy tudzież paznokcie są wyjątkowo podatne na praktyki magii sympatycznej, w związku z czym, w zgodzie z ówczesnymi normami kultury, były niszczone bądź ukrywane w miejscach

${ }^{41}$ Opisana historia przypomina odnotowaną w kronice Galla Anonima (I.1, 3, s. 11-14) opowieść o marnym końcu żywota gnieźnieńskiego księcia Popiela, który - będąc władcą niegodnym - zginął zagryziony przez myszy (zob. Banaszkiewicz 2010, s. 175 i n.). 
o utrudnionym dostępie, jako substancje tabuizowane, czyli niebezpieczne społecznie ze względu na ich potencjalne możliwości magiczne. $\mathrm{Z}$ kolei do tabuizacji wydzielin oraz zwierzęcych pasożytów ludzkiego ciała mógł przyczynić się odnotowany przez antropologię w kulturach ludów tzw. tradycyjnych czynnik fascynacji wspomnianymi substancjami, które intrygowały jako elementy kulturowo dwuznaczne, ponieważ należały do ciała, a jednocześnie traciły z nim kontakt. W tym charakterze funkcjonowały one jako obiekty graniczne, stanowiące przedmiot najsilniejszego tabu (Wasilewski 1987, s. 26 i n.).

Być może wymienione czynniki stanowiły przyczynę, dla której krążąca między Rusami misa, wypełniona wodą, mimo widocznego zanieczyszczenia, nie była opróżniana w trakcie kolejnych, analogicznych cyklów obrzędu. Pamiętajmy też o poglądach, w kulturach ludowych Europy podzielanych jeszcze niedawno, które głosiły odwieczny, tajemniczy charakter zbiorników oraz cieków wodnych, pełnych pierwotnego chaosu, w związku z czym zgromadzoną w nich wodę postrzegano jako żywioł o szczególnych walorach magiczno-sakralnych (por. P. Kowalski 1998, s. 609-615).

Wydaje się, iż po usunięciu wspomnianych nieczystości z ciała ludzkiego usiłowano skrupulatnie przywrócić je sferze chtonicznej, czyli powiązanemu z wodą Podziemiu, którego nie uznawano za ekumenę. Ludy tzw. indoeuropejskie, w tym Skandynawowie doby wikińskiej, traktowali bowiem świat chtoniczny jako naturalną, budzącą grozę siedzibę m.in. demonów, potworów oraz wszelkiego rodzaju plugastwa ożywionego przez złe moce ${ }^{42}$. Znamienne, iż w analizowanym przypadku ani demonów, ani ich substytutów nie próbowano zniszczyć (uśmiercić), może ze względu na przekonanie o związkach wspomnianych istot $\mathrm{z}$ odwiecznymi mocami tajemniczej genezy, których unicestwienie nastąpi dopiero $\mathrm{w}$ dniu ostatecznym, czyli według Skandynawów w dniu wypełnienia się „Losu bogów”, zwanego Ragnarök (por. Kempiński 2003, s. 172-174; Słupecki 2003, s. 57 i n.). Przypomnijmy, iż w opisanym powyżej obrzędzie asyryjskim naczynie $\mathrm{z}$ nasyconymi chorobą włosami króla zostawiono poza granicą ekumeny, bo tak zapewne należy rozumieć informację o pograniczu wrogiego kraju. Niestety, nie dysponujemy danymi o miejscu deponowania przez Rusów wody zanieczyszczonej w trakcie kolejnych cyklów ablucji oraz czesania włosów. Raczej nie wylewano jej w obrębie hali, kierując się względami higienicznymi oraz symbolicznymi walorami tego rodzaju budynków (por. Jørgensen 2005; 2009). Można zakładać, że usuwano ją

${ }^{42} \mathrm{~W}$ związku z tym Kościół posługuje się w swych obrzędach wodą święconą. Dodajmy, że w średniowieczu zbiorniki, akweny oraz cieki wodne były oczyszczane przez Kościół z zamieszkujących je złych duchów w momencie usuwania z zawłaszczanego przez chrześcijaństwo miejsca (tożsamego z mikrokosmosem) śladów starych, plugawych kultów pogańskich. Zjawisko doskonale ilustruje opisany przez Thietmara (VII.72 [52], s. 570) przypadek Reinberna, biskupa nadbałtyckiego Kołobrzegu, który zapewne w 1000 r., czyli po objęciu diecezji, uroczyście utopił w morzu cztery kamienie pomazane świętym olejem oraz pokropione święconą wodą. W ten sposób, według relacji tudzież opinii Thietmara, będącego również biskupem, Reinbern oczyścił morze z przebywających tam złych duchów. 
poza granicami własnego terytorium (czyli przynajmniej poza granicą hali) bądź wylewając do wyżłobionego w ziemi dołka albo do koryta pobliskiej Wołgi, w tym przypadku w specjalnie wybranym ku temu miejscu. Druga ewentualność wydaje się bardziej prawdopodobna, zważywszy na graniczny bądź transgraniczny charakter rzek, wyraźnie odnotowany w przekazach mitologicznych większości ludów tzw. indoeuropejskich, m.in. Skandynawów, przez co wody rzek, jak również ich brzegi oraz znajdujące się w dolinach cieków - wyspy lub półwyspy, spełniały kryteria potencjalnych miejsc ofiarnych bądź miejsc mediacji (por. P. Kowalski 1998, s. 502-508, 612-613; Chudziak 2009; Chudziak, Pranke i Kaźmierczak 2014). Za ustronnym pograniczem, zwłaszcza brzegiem rzeki, ewentualnie „prastarym” lasem, przemawia też sygnalizowany powyżej lęk ludzi średniowiecza przed utratą skutecznej kontroli nad istotnymi dla ludzkiej egzystencji magicznymi substytutami ciała, reprezentowanymi przez odcięte (odgryzione) paznokcie oraz wyczesane, wyrwane lub odcięte włosy.

Mając na uwadze symbolikę ,pogranicza”, warto wskazać na jeszcze jeden aspekt analizowanego obrzędu Rusów. Ablucja, w tym interesujący nas gest czesania włosów, dokonywała się rano, czyli w momencie rozgraniczającym mroczną, budzącą grozę noc, okres szczególnie podatny na działanie sił chtonicznych, zwłaszcza potworów i demonów, od jasnego dnia, czyli okresu wypełnionego działaniem bardziej pozytywnych dla ludzi, bo uranicznych (niebiańskich) mocy sakralnych $^{43}$. W tym przypadku pod „sztafażem” zwykłych, porannych zabiegów higienicznych należy domyślać się rytu tzw. przejścia, który poprzez oczyszczenie ciała, łącznie z uporządkowaniem włosów głowy za pomocą grzebienia (tzw. operatora zmiany), w magiczny, a zarazem czytelny sposób wyłączał człowieka z chaosu Nocy, jednocześnie wprowadzał w ustalony boskimi wyrokami porządek czekających go za Dnia obowiązków oraz czynności. Za powyższą interpretacją przemawia fakt, iż w różnych kulturach Europy starożytnej i średniowiecznej Poranek, Południe, Zmierzch oraz Północ traktowane były jako cykliczne odcinki czasu, wymagające od ludzi nadzwyczajnej czujności oraz szczególnych reakcji ochronnych w momentach granicznych (marginalnych), wspartych każdorazowo praktykami magii i/lub religii. Wynikało to z przejściowego charakteru wymienionych przedziałów czasu, które niosąc ze sobą temporalny oraz kulturowy chaos o skutkach trudnych do przewidzenia, wywoływały w społecznościach poczucie różnorodnych zagrożeń. Interesujący nas ryt winien zatem zabezpieczać człowieka przed działaniem zła lub innych groźnych mocy (m.in. czarnej magii), jednocześnie

${ }^{43}$ Por. P. Kowalski 1998, s. 460-465. W tym kontekście wagi nabiera informacja przekazana przez staronordycką Eddę poetycka, dzieło spisane ostatecznie w XIII w., iż „Bogowie wszyscy sejm wielki zwołali, / I Nieśmiertelni tak nad sprawą radzili: / Miesiącowi na nowiu i Nocy imię dali, / Poranek nazwali i Południe takoż, / I Podwieczerz i Wieczór [wyróżnienie - M.K.], by móc liczyć lata” („Völuspá” 6, s. 4-5). Zatem obliczanie czasu, mierzone cyklami księżyca oraz wędrówką słońca po nieboskłonie, według mitologii normańskiej było dziełem bogów. Fazy dnia i nocy miały więc sakralny wymiar, co czyniło je podatnymi na działanie mocy nadprzyrodzonych. 
winien pobudzać w człowieku wrodzone siły życiowe oraz charyzmatyczne przymioty pomocne w egzystencji (w przypadku przywódcy ważne też dla bytu wspólnoty), na przykład odwagę, spryt, tężyznę fizyczną, zdrowie, płodność, mądrość, rozwagę, urodę czy pobożność.

Wnosząc $\mathrm{z}$ opisu ablucji Rusów, kluczową rolę $\mathrm{w}$ tamtejszym rycie przejścia odgrywał moment czesania grzebieniem umytych włosów głowy. W sekwencji gestów towarzyszących oczyszczeniu (naliczyliśmy ich sześć) była to czynność kulminacyjna, rozgraniczała bowiem czynności mycia rąk (1), twarzy (2) oraz włosów (3) od czynności usuwania wydzielin z nosa (5) oraz prawdopodobnie z ust (6). Dla prawidłowego przebiegu rytu nie wystarczało zatem umycie wybranych partii ciała. Warunkiem koniecznym, pozwalającym skutecznie odseparować się od wpływu złych mocy, a jednocześnie otworzyć na działanie pozytywnych sił sakralnych (?), było uporządkowanie osobistym grzebieniem umytych uprzednio włosów w określoną fryzurę, którą traktowano zapewne jako czytelny znak dopełnienia obrzędu (rytu przejścia).

Znamienne, iż do tej samej zasady odwoływał się w średniowieczu także Kościół Rzymski. W jednym z rytuałów nakazywał on celebransowi, bezpośrednio przed rozpoczęciem mszy świętej, uczesać włosy za pomocą grzebienia tzw. liturgicznego, który stanowił najprawdopodobniej element wyposażenia ołtarza (Schnitzler 1960; K. Ambrosiani 1981, s. 13; Górecki 2000; Merhautová 2000). Kapłan oczyszczał w ten sposób swe myśli z grzechów, a jednocześnie wyłączał się $\mathrm{z}$ chaosu życia codziennego i wprowadzał w stan ładu, który umożliwiał mu kontakt z sacrum podczas ofiary mszy świętej. Świadczy o tym formuła modlitwy zawarta w Missale Lundense z początku XII w. (Lund należał wówczas do Danii), odmawiana przez księdza podczas czesania głowy: „Corripe me, Domine, in misericordia tua” (zob. Tesch 1992, tamże dalsza literatura). Wierzono, że Chrystus wnikał w kapłana poprzez uczesaną głowę, przy czym warunkiem zaistnienia tej szczególnej relacji z Bogiem było oczyszczenie włosów grzebieniem tudzież ich uporządkowanie w określoną fryzurę, wsparte cytowaną modlitwą. W tym przypadku grzebień pełnił ważną rytualnie funkcję tzw. operatora zmiany (instrumentu znanego etnologii i etnografii - zob. P. Kowalski 1998, s. 609), którego użycie prowadziło do przewartościowania statusu osoby uczestniczącej w rytuale oraz jej kontekstu kulturowego. Warto nadmienić też o możliwości stosowania w średniowiecznym Kościele katolickim ozdobnych grzebieni, wykonanych zwykle z kości słoniowej, w liturgii mszy pontyfikalnej oraz w obrzędzie konsekracji biskupa, konkretnie w akcie pomazania głowy kandydata olejami świętymi (Frutaz 1952; Schnitzler 1960; K. Ambrosiani 1981, s. 13; Muhl 1990, s. 126-127). Dzięki wspomnianemu sakramentowi spływała na biskupa łaska oraz moc Boga, czyniące zeń pomazańca. Dodajmy, że w przypadku kanonizacji biskupa, użyty podczas konsekracji grzebień tzw. liturgiczny zyskiwał status relikwii drugiego stopnia jako przedmiot zwierający cząstkę mocy świętego. Wspomnianą moc zyskiwał grzebień już za życia biskupa wskutek kontaktu z jego włosami. 
W świetle powyższych ustaleń nie sposób wątpić w magiczne konotacje zabiegów higienicznych, zwłaszcza mycia rąk i twarzy oraz czesania włosów głowy, jakie praktykowali wczesnośredniowieczni Rusowie. Wspomniane czynności, powiązane z rytem tzw. przejścia, gdzie pełniły funkcję magiczno-sprawczych gestów i/lub znaków kulturowego stanu, najprawdopodobniej realizowane były w okolicznościach nieprzypadkowych, czyli w trakcie ustalonych pór doby (np. poranna ablucja), jak też w określonych sytuacjach granicznych o trudnych do przewidzenia skutkach (np. przed wyprawą na łowy, na połów, na handel, do obcego kraju, przed pojedynkiem lub bitwą, w momencie zagrożenia śmiercią lub chorobą, w momencie przygotowania zwłok do pogrzebu).

Istnienie podobnego zjawiska należy dopuszczać też w systemach społeczno -kulturowych innych ludów, w tym Skandynawów okresu wikińskiego. Instruktywny w tym względzie wydaje się przekaz Wieszczej Pieśni Wölwy, zawarty w staronordyckiej Eddzie poetyckiej, według której po tragicznej śmierci boga Baldra jego przyrodni brat Wali, syn boga Odina, „Rąk nie mył wcale ni włosów nie czesał, / Póki nie przywiódł na stos wroga brata [...]” („Völuspá” 34, s. 12). Niezależnie od interpretacji, upatrujących w Walim bądź młodzieńca tuż po rytualnej inicjacji społecznej, bądź jednodniowego noworodka, sens dokonanego przez boga gestu czyni zeń bohatera klasycznego rytu przejścia. $Z$ chwilą umycia rąk oraz uczesania włosów Wali przeszedł ze stanu typowego dla dzikiej Natury, w jakim tkwił, zanim nie dokonał pomsty, do stanu uspołecznionego, który zaczął mu przysługiwać dopiero jako herosowi.

W podobny sposób wymienione wyżej stany waloryzowane są w kulturze ludowej Słowian, co świadczy o powszechności zjawiska. Wyniki badań etnograficznych wskazują, iż w słowiańskiej mentalności ludowej istnieje przekonanie o semantycznych relacjach łączących kolory włosów człowieka z maścią zwierząt udomowionych, przy jednoczesnych antyrelacjach wspomnianego ubarwienia z sierścią zwierząt dzikich. Owłosienie uznaje się bowiem za cechę wspólną ludzi i zwierząt; w tym przypadku wskazuje się zwłaszcza na konie, wilki, psy, świnie i niedźwiedzie (Banek 2010, s. 218 i n.; patrz też Słupecki 2011). O ile owłosienie normalne i uporządkowane, zgodne z obowiązującymi normami społeczno-kulturowymi, sytuuje człowieka bliżej zwierząt udomowionych, o tyle nadmierne, brudne i zmierzwione zbliża właściciela zarówno do zwierząt dzikich i nieoswojonych, jak i do istot demonicznych, owłosionych na sposób zwierzęcy. Wzorem zwierząt udomowionych, które w opisach świata ludów tzw. tradycyjnych lokowane są zwykle na pograniczu Natury i Kultury, także włosy cechuje ewidentny status materii mediacyjnej. Panuje przekonanie, iż w zależności od sposobu potraktowania, włączają one człowieka w sposób czytelny i społecznie aprobowany w świat Cywilizacji bądź oddają go dzikiej i groźnej sferze Natury (Libera 1987, s. 118 i n., tamże dalsza literatura).

Do poczynionych uwag dodajmy jeszcze jedną, tym razem sformułowaną na podstawie obserwacji obyczajów starożytnych Spartan. I tak w opisie przygotowań 
wojsk helleńskich do obrony Termopil przed Persami (sierpień roku 480 p.n.e.), pióra Herodota (VII.207-211, s. 187-188), znajdujemy informację, iż Lecedemończycy, zanim przystąpili do śmiertelnego boju, gimnastykowali się i czesali włosy, czyniąc to $\mathrm{w}$ formie zbiorowego obrzędu. W ten sposób, w zgodzie $\mathrm{z}$ własnym obyczajem, niezrozumiałym dla Persów (!), szykowali się na ryzyko utraty życia w krwawej bitwie. Nie ulega wątpliwości, że również w opisanym przypadku mamy do czynienia $\mathrm{z}$ wstępną fazą sytuacji granicznej. Wprawdzie pod względem uwarunkowań ontologicznych jest ona odmienna od sytuacji opisanych powyżej, przygotowuje bowiem wojowników (potencjalnych herosów) do spodziewanego momentu przejścia $\mathrm{z}$ oswojonego świata Kultury do nieznanego świata Śmierci i niepewności eschatologicznego losu, to jednak pozostaje z nimi zbieżna w zakresie celu zastosowanego obrzędu czesania włosów i porządkowania ciała. Obrzęd ów miał zapewne ułatwiać uczestnikom rytuału - niczym chrześcijański viatyk zmianę ich stanu w momencie śmierci, czyli w sytuacji granicznej, a zarazem uodporniać na wszelkie niepokoje i zagrożenia, których można doświadczyć w momencie przejścia $\mathrm{w}$ Zaświaty.

Kontakt z włosami - magiczną materią ludzkiego ciała - sprawiał zatem, iż przybory toaletowe, zwłaszcza grzebienie, traktowane były przez różne ludy (por. Kwapiński 1998, s. 99 i n., tamże dalsza literatura), w tym przez Skandynawów wczesnego średniowiecza, jako przedmioty o znaczeniu szczególnym, związane m.in. $\mathrm{z}$ wierzeniami eschatologicznymi. $\mathrm{Z}$ tego powodu grzebiennictwo germańskiej strefy kulturowej, zwłaszcza nurtu typowego dla wczesnośredniowiecznych Fryzów oraz Skandynawów, które w sposób zasadniczy oddziaływało na rzemiosło rogownicze Słowian Zachodnich, głównie nadbałtyckich, od początku miało charakter elitarny. Dodajmy, że grzebienie, nożyce, brzytwy, pincety oraz misy należą do znalezisk często rejestrowanych $\mathrm{w}$ grobach arystokracji germańskiej późnej starożytności i wczesnego średniowiecza, w tym uznawanych za pochówki władców, aczkolwiek notowane są również w kulturze funeralnej innych ludów. Uważa się, iż w grobach były deponowane z przyczyn symbolicznych (zob. Vierck 1972, s. $34-40)^{44}$.

${ }^{44}$ W tym kontekście warto odwołać się do dwu odkrytych w Björkö/Birce grobów tzw. komorowych, kryjących szczątki kobiet, które pogrzebano w rycie inhumacji. Grób nr 581 pochodzi z początku lub 1. połowy X w. (zawierał m.in. dirhem samanidzkiego emira Nasra ibn Ahmada wybity w latach A.D. 913-933), natomiast obiekt nr 854 synchronizowany jest z IX stuleciem (Arbman 1943, s. $188-190,326-330$, ryc. 143; 274-275). Każdy z pochówków ujawnił w pobliżu kości stóp szkieletu ornamentowany, uszkodzony grzebień z poroża, leżący w sąsiedztwie dużej misy brązowej. Grzebień z grobu nr 854 zamknięty był wraz ze szklanym tzw. gładzikiem w okutej skrzynce drewnianej. Jest to jedyny tego rodzaju przypadek stwierdzony w Birce. Z kolei grzebień z grobu nr 581 reprezentuje ten sam typ, co okaz ze Stroszek, a jego okładzinę zdobi umieszczony w centralnej partii motyw misternie wyrytej quasi-sieci, czym również przypomina wspomniany grzebień (ryc. 9:6).

Odnotujmy, że kobieta pochowana w grobie nr 581 (chodzi o osobę w wieku co najmniej 30 lat, której biologiczną płeć ustalono metodą analizy kopalnego DNA) pogrzebana została w pozycji tzw. siedzącej, typowej m.in. dla kultury funeralnej elit birczańskich i ruskich (Gräslund 1980), w ekskluzywnej czapce wschodniej proweniencji (swego rodzaju kołpaku-koronie?), z luksusowym uzbrojeniem 
(!), rzędem końskim, dwoma końmi i odważnikami wagowymi (zapewne kośćmi do rzucania w grze losowej) tudzież planszową grą hnefi, prawdopodobnie w typie szachów (ryc. 13). Sądząc z inwentarza grobowego, należała ona do najwyższych kręgów ówczesnej arystokracji, której członkom, jak również zbrojnym członkiniom, przysługiwała - zdaniem badaczy - szczególna pozycja w strukturze hirdu, osobistej drużyny normańskich królów, królowych lub jarlów (Hägg 2002, s. 200 i n.; Hedenstierna-Jonson i in. 2017; Price i in. 2019; patrz też Oddr Snorrason 8, s. 38-39). Dodajmy, iż według skandynawskich źródeł pisanych okresu średniowiecza, w społecznościach normańskich epoki wikińskiej funkcjonowały nierzadko niewiasty, które w świetle wspomnianych przekazów literackich, głównie o charakterze legendarnym, brały czynny udział w zbrojnych starciach $\mathrm{z}$ mężczyznami bądź uczestniczyły u ich boku - niczym walkirie Odina - w krwawych bitwach, gdzie m.in. niosły znaki/ proporce (zob. np. Kronika królów z Lejre 9, s. 32). Tej funkcji nie jesteśmy skłonni przypisać kobiecie pochowanej w grobie nr 581; domyślamy się jednak jej szczególnej pozycji w ówczesnej społeczności jako zbrojnej członkini hirdu. Kluczowe znaczenie dla proponowanej hipotezy ma, naszym zdaniem, stwierdzona w wymienionym grobie pozostałość losowej gry hnefi, typowej dla kultury Skandynawów okresu wikińskiego, której archetyp być może stanowily wspomniane w staroeddaicznej Wieszczbie Wölwy („Völuspá” 61, s. 17) złote tablice Asów, pozwalające rządzić przeznaczeniem. Z tego powodu wspomniana gra hnefi mogła służyć przewidywaniu przyszłości, a z racji podobieństwa planszy do użytej przez Lokiego sieci rybackiej, o czym pisaliśmy powyżej (zob. ryc. 5:2), mogła być też przydatna w zaklinaniu (pętaniu) Losu/Przeznaczenia, a tym samym wymuszaniu zwycięstwa w bitwie. Tego rodzaju działania, łącznie ze złożeniem krwawej ofiary z osoby bliskiej, jako ostatecznego sposobu zyskania przychylności sił nadprzyrodzonych, Normanowie uznawali za powinność wodza lub króla - przywódcy hirdu (zob. np. Oddr Snorrason 18, s. 61). W tym kontekście warto przywołać odnotowaną przez Pawła Diakona historię Rodulfa, króla północnogermańskich Herulów, który podczas krwawej bitwy stoczonej z Longobardami w 508 r. n.e. prawdopodobnie nad dolnoaustriacką lub południowomorawską rzeką Morawą, będąc wodzem przezornym, próbował uzyskać zwycięstwo od sił wyższych, grając z Losem w grę, którą prowadził przy własnym stole (Historia Longobardów I.20, s. 210; zob. też Kasperski 2017a; Banaszkiewicz 2018a). I. Lewandowski, thumacz cytowanego dzieła Pawła Diakona, domyśla się we wspomnianej grze tzw. damki, odmiany szachów (Historia Longobardów, s. 338, przypis 48), a J. Banaszkiewicz (2018a) gry losowej polegającej na rzucaniu kośćmi. Nie wykluczamy zatem, iż uwidoczniona w pochówku nr 581 z Birki szczególna pozycja pogrzebanej tam niewiasty, złożonej zgodnie z rytuałem przysługującym elitarnym wojownikom konnym tych czasów, wynikała $\mathrm{z}$ jej profetycznych umiejętności, które ujawniała przed lub w trakcie bitwy, grając w hnefi z Losem o zwycięstwo jako realny lub symboliczny wódz hirdu (por. Kara 2016a, s. 378, gdzie podobne ustalenia dotyczące żeńskich pochówków z okresu wikińskiego, zawierających składane wagi szalkowe). Dodajmy, że w myśl ówczesnych przekonań umiejętności magiczne przypisywane były zwłaszcza dziewczętom i kobietom, także wywodzącym się z najwyższych kręgów władzy (zob. Price 2002; Gräslund 2007).

Bliską analogią do pochówka nr 581, w zakresie rodzaju oraz charakteru inwentarza, jest męski grób komorowy z okresu wędrówek ludów, odkryty w m. Högom w Norrland, w północnej części środkowej Szwecji (Ramqvist i Müller-Wille 1988). Na szczególną uwagę zasługuje odnotowany we wspomnianym grobie jednorzędowy grzebień z poroża, który został ulokowany w obrębie dużej misy brązowej, przy czym zębami zwrócony był w kierunku zwłok. Misę ustawiono w pobliżu nóg zmarłego, prawie na osi ciała (z niewielkim odchyleniem w kierunku prawej strony), czyli podobnie jak w grobie nr 581 z Birki, z tym że w tym ostatnim na osi ciała znajdował się tylko grzebień zwrócony zębami w kierunku zwłok, a misa spoczywała tuż przy nogach i grzebieniu, po ich prawej stronie. Mimo ewidentnych różnic, także dotyczących chronologii pochówków, stwierdzone między nimi zbieżności w zakresie obrządku pogrzebowego są bardzo wyraźne, co nie wydaje się okolicznością przypadkową.

Z przytoczonych względów zdeponowane w elitarnych grobach z obszaru Skandynawii misy brązowe skłonni jesteśmy - wraz z towarzyszącym im grzebieniem - zestawiać ze zreferowaną powyżej informacją Ibn Faḍlāna o wielkiej misie wypełnionej wodą, do której brud z włosów wyczesywali uczestniczący w obrzędzie ablucji zamożni Rusowie. Bardzo prawdopodobne, że analizowane zjawisko miało szerszy kontekst etno-kulturowy. Świadczą o tym datowane na okres merowiński szkieletowe, bogato wyposażone groby m.in. komorowe, kryjące zwłoki uzbrojonych mężczyzn, z grzebieniem we wnętrzu dużej misy brązowej lub w jej pobliżu, odkryte na terenie Niemiec zachodnich (zob. Thieme, Laux i in. 1978, s. 666-678, nr 450; Müller-Wille 1980, s. 150 i n.). W tym nurcie rozważań mieści się też znalezisko stwierdzone w słynnym anglosaskim grobie łodziowym z m. Sutton Hoo (Suffolk) w Wielkiej Brytanii. Natrafiono tam na kanelurowaną misę srebrną, zawierającą m.in. dwa grzebienie 
Podsumujmy zatem poczynione ustalenia. Pozwalają one uznać „rogowy” grzebień z wczesnośredniowiecznej osady w Stroszkach pod Gieczem, zalegający w obiekcie nr 164, za ekskluzywny wyrób rzemiosła skandynawskiego - tzw. jednostkowy lub krótkiej serii, pochodzący ze środkowego okresu wikińskiego. Jego ornamentyka ujawnia bliskie podobieństwo do zdobnictwa grzebieni zapewne fryzyjskich z IX względnie początku X stulecia. Reprezentuje on typ IB-VIII-1a według klasyfikacji E. Cnotliwego, popularny w IX/X-X/XI w. przede wszystkim w regionie basenu Morza Bałtyckiego (Cnotliwy 1973; 1993; 2013). Wnosząc z datacji analogii (m.in. fryzyjskich), interesujący nas grzebień wykonano najprawdopodobniej na przełomie IX i X lub w 1. połowie X wieku. W jamie nr 164 (zapewne pozostałość obiektu mieszkalnego) współwystępował on z zespołem ceramiki naczyniowej charakterystycznym dla faz $\mathrm{B} / \mathrm{D}_{0}-\mathrm{D}_{0}$ wczesnego średniowiecza w centralnej Wielkopolsce, których górną granicę chronologii wyznacza 3. ćwierć X stulecia (Kara 2009, s. 253 i n.). Homogenny charakter zespołu pozwala określić ramową metrykę obiektu na koniec IX-początek 2. połowy X w. (por. Brzostowicz 1996, s. 272, tam zbliżona datacja).

Grzebień ze Stroszek wpisuje się zatem w ten sam przedział czasu (generalnie X w.), co okazy typu IB-VIII-1 oraz IB-VIII-2 według E. Cnotliwego (tożsame z typem „Birka” wymienionego badacza), które w liczbie 11 egzemplarzy, w tym 1 bardzo niepewny ${ }^{45}$, zarejestrowano na Pomorzu Zachodnim w reliktach rzemieślniczo-handlowych lub wczesnomiejskich ośrodków w Wolinie, Kamieniu Pomorskim oraz Kołobrzegu-Budzistowie, bądź w ich najbliższym sąsiedztwie (Wrzosowo, pow. Kamień Pomorski), jak również na przyległej do Pomorza Wysoczyźnie Elbląskiej - tam w pozostałościach wczesnośredniowiecznego emporium stwierdzonego w Janowie (Pomorskim), przekonująco łączonego z historycznym Truso (zob. Cnotliwy 1973, s. 148-154, ryc. 63; 1993, s. 355 i n., ryc. 16; 2013, s. 75-76, ryc. 41).

Należy podkreślić, iż wspomniane grzebienie są - jak dotąd - jedynymi tego rodzaju znaleziskami w dorzeczu Odry i Wisły, które koncentrują się wyłącznie w przybrzeżnej partii Pomorza oraz na jego wschodniej peryferii. Rysujący się związek dotyczy z jednej strony luksusowych i charakterystycznych wyrobów kul-

oraz fragment splecionego warkocza z włosów (Vierck 1972, s. 24-25, ryc. 2.A1:8-9). Grób, ze względu na zbieżności z elitarną kulturą Szwecji wcześniejszego średniowiecza (zob. Sandwall [red.] 1980), datowany jest na starsze stadium okresu Vendel. Pochówek nie ujawnił szczątków ludzkich. Przypuszcza się, iż był to grób przygotowany dla Raedwalda, „króla” wschodniej Anglii, który zmarł około roku 624/625 (Evans 1989).

Dodajmy, iż według interpretacji D. Ellmersa (1964/1965), pochodzace z okresu wikińskiego misy brązowe, m.in. odkryte na cmentarzyskach w Birce, to prawdopodobnie naczynia używane do mycia rąk. Nie jest to jednak pogląd powszechny w nauce (zob. Trotzig 1984, s. 226-228).

${ }^{45}$ Chodzi o uszkodzoną skrajną płytkę zębatą grzebienia odkrytą w Wolinie, którą E. Cnotliwy (1973, s. 150, ryc. 51a) zaliczył do typu IB-VIII-1. 


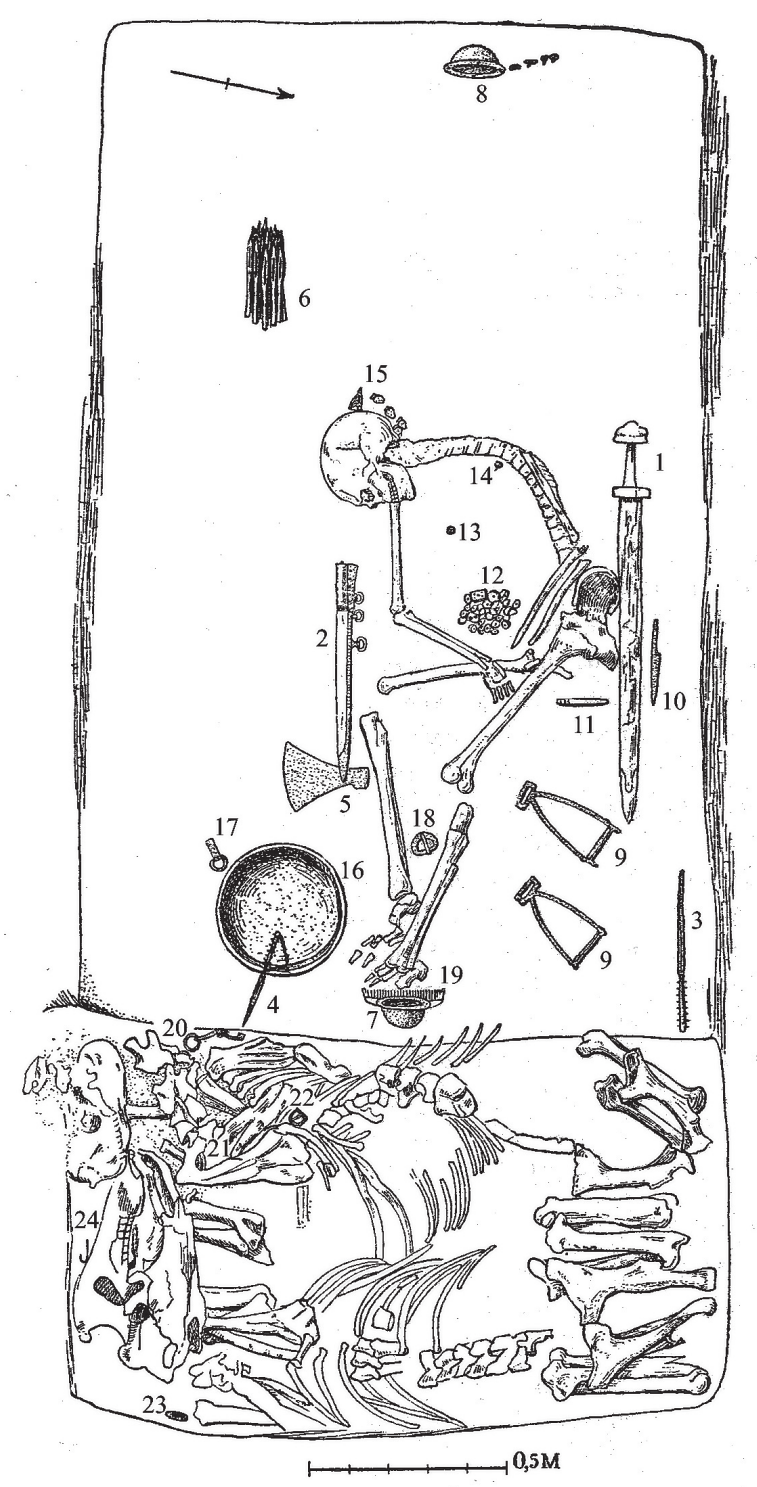

Ryc. 13. Datowany na 1. połowę X w. komorowy grób nr 581 z Björkö/Birki (Szwecja-Uppland), zawierający szkielet kobiety pogrzebanej w tzw. pozycji siedzącej, z dwoma końmi, na sposób typowy dla elitarnych wojowników (1-8 - uzbrojenie; 9, 18, 20-24 - elementy rzędu końskiego; 10 - żelazny nóż; 11 - osełka lub kamień probierczy; 12 - piony i kości do gry hneftafl wraz z odważniakmi wagowymi; 13 - dirhem arabski z A.D. 913-933; 14 - żelazna szpila lub zapinka pierścieniowata; 15 - srebrne elementy nakrycia głowy w typie kołpaka; 16 - reperowana misa brązowa; 17 - żelazna przewleczka rzemienia lub pasa; 19 - grzebień z poroża). Według Arbman 1943, ryc. 143 (z modyfikacją). Opracowanie komputerowe J. Sawicka 
tury skandynawskiej ze środkowego okresu wikińskiego, z drugiej zaś osiedli lub rejonu z potwierdzonymi archeologicznie śladami wysoce prawdopodobnej obecności Normanów wśród miejscowych społeczności zachodniosłowiańskich, a w przypadku Truso w obrębie pogranicza słowiańsko-pruskiego (Łosiński 1994; 2008; Jagodziński 2010; Jöns i Kowalska 2018).

Niewielka liczebność znalezisk wyklucza raczej udział interesujących nas grzebieni (jako liczącego się importu) w wymianie handlowej między wczesnomiejskimi, polietnicznymi ośrodkami Skandynawii (Hedeby, Birka), może też między emporiami wschodniej części Wysp Brytyjskich (przede wszystkim York) a ludnością wczesnomiejskich lub rzemieślniczo-handlowych osiedli zlokalizowanych na południowym wybrzeżu Bałtyku, którą na podstawie analizy źródeł sygnalizują archeolodzy (na ten temat Łosiński 2008; odmienne ujęcie zob. Sindbæk 2007).

Więcej przemawia za związkiem wspomnianych grzebieni z popularną wśród ludów ówczesnej Europy Północnej i Środkowo-Wschodniej instytucją wymiany tzw. ceremonialnej, której stron - w przypadku wyżej wymienionych osiedli pomorskich - upatrywać należy wśród członków lokalnych elit słowiańskich oraz trudniących się m.in. handlem przedstawicieli świata wikingów z Europy Północnej i Rusi, głównie Skandynawów. Nie można wykluczyć też wśród wspomnianych grzebieni okazów zagubionych lub wyrzuconych przez przybyszów z powodu destrukcji. Niezależnie od specyfiki „,importu”, grzebienie pochodzenia germańskiego w zetknięciu z kulturą Słowian twórczo oddziaływały na miejscową produkcję grzebienniczą.

Należy zakładać, iż w dorzeczu Odry i Wisły, zwłaszcza u Słowian nadbałtyckich, których kultura - identycznie jak Normanów - była wyraźnie powiązana z żywiołem wodnym, zwłaszcza z morzem, wczesnośredniowieczne grzebienie posiadały atrybuty podobne lub identyczne $\mathrm{z}$ atrybutami grzebieni używanych ówcześnie przez Germanów, mimo dzielących oba ugrupowania etniczne różnic w zakresie wyznawanej wiary pogańskiej ${ }^{46}$. W tym przypadku w grzebieniach, niezależnie od ich funcji utylitarnej (utensylia pomocne w utrzymaniu higieny ciała), domyślamy się również przyborów o funkcji antydemonicznej, których przydatność ujawniała się w sytuacjach granicznych, zwłaszcza w momentach różnorodnych zagrożeń, łącznie $\mathrm{z}$ groźbą utraty życia (zwłaszcza na morzu), jak również $\mathrm{w}$ różnorodnych obrzędach przejścia, na przykład związanych z postrzyżynami czy pogrzebem. W tym ostatnim przypadku grzebienie mogły pełnić zespolone funkcje magicznych operatorów zmiany oraz apotropaicznych instrumentów tzw. kolczych, na przykład jako narzędzia przydatne w toalecie zwłok tudzież w zarysowaniu granicy grobu, jednocześnie skuteczne w odstraszaniu złych mocy,

${ }^{46}$ W kwestii pogańskich kultów Germanów i Słowian zob. opracowanie M. Müller-Willego (1999), prezentujące zagadnienie z perspektywy archeologicznej. Por. też Steinsland 1992; Simek 2003. 
z racji swych kolczych uwarunkowań ${ }^{47}$. Być może z powodu przekonania o szczególnych związkach łączących je z magią, czyli sferą chtoniczną, grzebienie ukrywane były - jako przedmioty potencjalnie niebezpieczne, a zarazem podatne na uszkodzenie - w woreczkach lub pochewkach ${ }^{48}$. Nadzwyczajne funkcje grzebieni winny zatem objawiać się w momentach, gdy ich właściciele szczególnie pożąda-

47 Jeszcze do niedawna wytyczenie granicy grobu uznawane było w Europie za czynność typowo apotropaiczną. W sensie symbolicznym można przyrównać ją do praktykowanego również w Europie zwyczaju ochrony stada zwierząt hodowlanych przed wilkami, które powszechnie uznawano za istoty quasi-demoniczne. Według tegoż zwyczaju, mającego charakter obrzędu, należało przed pierwszym wypasem otoczyć w celach ochronnych stado magicznym kręgiem, zaznaczając granicę na przykład zębami brony, czyli przedmiotem ,pokrewnym” grzebieniowi (Moszyński 1967, s. 321-323, tam pojęcie koła magicznego; P. Kowalski 1998, s. 602).

48 Nie można wykluczyć, że część grzebieni odkrytych na cmentarzyskach ludności wczesnomiejskiej osady w Birce, zarejestrowanych w pobliżu tułowia lub w rejonie bioder osób zmarłych, zwykle po prawej stronie, pierwotnie mogły być nakryte obszerną peleryną lub płaszczem, mogły też znajdować się w niewielkich sakwach lub mieszkach przytwierdzonych do pasa (zob. męski grób nr 955, gdzie stwierdzony w rejonie prawej [?] kości miednicy ozdobny grzebień, zaopatrzony w żelazną wkładkę zapewne do krzesania ognia, leżał wraz z nożem, osełką, skałką, resztką skórzanego woreczka [?] i szpilą tzw. pierścieniowatą, służącą do spinania szat, głównie płaszczy - Arbman 1940, tabl. 163:11; 1943, s. 379-380). Do tej grupy należy dodać grzebienie odkryte w dwu grobach kobiecych: nr 964 oraz nr 980. Pierwszy został położony przy prawym kolanie zmarłej, drugi przypuszczalnie pod plecami, na styku z prawym biodrem - czyli w miejscach nietypowych (Arbman 1943, s. 389, 406-408).

Z faktu zalegania grzebieni „,birczańskich” na kościach miednicy szkieletu lub w jej pobliżu, zwykle po prawej stronie zwłok, tożsamej z pozytywną pod względem symbolicznym stroną ciała ludzkiego (zob. Wasilewski 1978; P. Kowalski 1998, s. 218-219; Kempiński 2001, s. 358-359; de Chapeaurouge 2014, s. 57-66; Banaszkiewicz 2018c), można wnioskować, iż pierwotnie stanowiły one elementy stroju zawieszone u pasa, na szyi (?) (np. męski grób nr 495 - Arbman 1943, s. 142-143) lub podwieszone do kolii (?) (np. żeński grób nr 978 - Arbman 1943, s. 404-406). Zapewne były to przedmioty osobistego użytku. Tę okoliczność sugeruje z kolei obecność niektórych grzebieni - pierwotnie zawieszonych u pasa (?) - na kościach dłoni lub bezpośrednio pod kośćmi nadgarstka (zob. groby nr 628, 1097 - Arbman 1943, s. 208-209, ryc. 166:10, s. 458), co przywodzi na myśl praktykowany powszechnie gest posiadania lub zawłaszczania czegoś na własność. Zob. też przypis 15 w niniejszym artykule.

$\mathrm{Z}$ analizy wspomnianych grzebieni wynika jeszcze jedna istotna dla naszych rozważań konstatacja. Były to przedmioty długo i/lub bardzo intensywnie użytkowane. Uwaga ta dotyczy również okazu odkrytego w Stroszkach, który podobnie jak większość grzebieni znalezionych w „barbarzyńskiej” części wczesnośredniowiecznej Europy (chodzi o okazy pochodzące nie tylko z cmentarzysk, lecz również z reliktów osad oraz grodów), ujawnia ślady wyraźnych uszkodzeń, głównie w obrębie płytki zębatej (ryc. 9). Skala tudzież podobieństwo destrukcji interesujących nas grzebieni nie wydają się przypadkowe. Być może przynajmniej części z nich celowo nie naprawiano. Wprowadzone do użytku grzebienie zyskiwały bowiem indywidualne moce właściciela włosów, co według norm kultury magicznej przeistaczało je w swego rodzaju substytuty człowieka, chronione w sposób szczególny przed szkodliwą ingerencją osób postronnych (przypomnijmy, w opisanym przez Ibn Faḍlāna obrzędzie ablucji Rusów, przechodnia misa z wodą, służąca poszczególnym uczestnikom zgromadzenia do mycia rąk oraz głowy, krążyła między nimi za pośrednictwem niewolnicy, a jej pan czesał się własnym [!] grzebieniem). Na tej podstawie można przypuszczać, iż do grobów trafiały osobiste grzebienie zmarłych, w większości przypadków wyraźnie uszkodzone podczas ich użytkowania (podobnie K. Ambrosiani 1981, s. 12-15). Wśród grzebieni „,birczańskich” notuje się jednak i takie egzemplarze (np. znalezione w grobach nr 86, 467A, 944, 978 - Arbman 1940, tabl. 161:6, 7, 9; 164:3; 1943, s. 37-38, 134, 368-371, 404-406, ryc. 321:10), które mogły zostać celowo zdekompletowane poprzez usunięcie wszystkich zębów. Przyczyna zjawiska, o ile trafnie odczytaliśmy jej charakter, jest trudna do ustalenia. 
li reakcji pozytywnych sił nadprzyrodzonych, jako gwarancji poprawy bieżącego losu, a jednocześnie skutecznej ochrony przed złem.

W proponowany nurt złożonej interpretacji funkcjonalnej grzebieni z obszaru wczesnośredniowiecznego Barbaricum europejskiego wpisują się również znaleziska z ziem polskich. Chodzi o stwierdzone w dorzeczu Odry i Wisły (zwłaszcza na Pomorzu Zachodnim i w sąsiedniej Wielkopolsce) okazy ekskluzywnych grzebieni z poroża, zaliczone do typu IB-VII-5b według E. Cnotliwego (1973, s. 104 i n.), które w centralnej partii okładzin posiadają krótkie, wyryte pasmo ukośnych linii lub ukośnej kratki w wąskim obramowaniu linii pionowych, wyraźnie przypominające motyw kratki-sieci znany ze skandynawskich grzebieni typu IB-VIII-1-2, w tym z okazu odkrytego w Stroszkach (ryc. 9; 14). W literaturze grzebienie typu IB-VII-5b uznaje się za formy charakterystyczne dla grzebiennictwa Wolina (Cnotliwy 1973, s. 113-115; Zamelska-Monczak 2014, s. 54-55). Ich wytwórczość - w świetle zweryfikowanej chronologii rzeczonego ośrodka, zwłaszcza pracowni rogowniczych odkrytych w dzielnicy „Srebrne Wzgórze” (Cnotliwy, Łosiński i Wojtasik 1986) - należy łączyć najpóźniej z 4. ćwiercią X wieku.

Związek tak ornamentowanych grzebieni ze sferą chtoniczną (powszechnie uznawaną za domenę magii, profetyzmu, bogactwa, śmierci, odradzania oraz demonów - zob. np. Kempiński 2001, s. 168-169 [hasło: Hades], 346 [hasło: Persefona]; Bates 2005) nie wydaje się przypadkowy. Sugerują go również zasoby leksykalne języków słowiańskich, w których stosowany w języku polskim rzeczownik „grzebień” (prawdopodobnie zapożyczony z języka czeskiego - Romaniak 2016), mający dobre odpowiedniki leksykalne we wszystkich językach słowiańskich (np. cerkiewno-bułgarski/serbski „,гребен” [,greben”], czeski „hřeben”, łużycki „grjebjeń”, rosyjski „гребень” [,greben“”]), nawiązuje pod względem

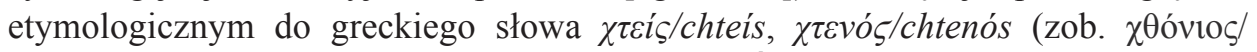

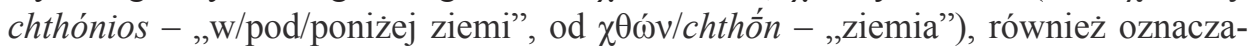
jącego grzebień. Rzeczownik „grzebień”, tudzież pokrewne mu słowo „zgrzebło”, łączą się bowiem z czasownikiem ,grzebać/grabić”, który w języku polskim zastąpił pierwotną odmianę „grześć”, ,grzeć” lub „grzebę”, co oznaczało „grzebienie ciał”, „pogrzebę”, „pogrzebł”, czyli generalnie akt porządkowania, również w sensie zasypywania ziemią (grzebania) ciała osoby zmarłej bądź usuwania go (w rozumieniu oddzielania - zob. „grób”, „grzonąć”, „odgrzonąć”) z obrębu ekumeny, co stanowi symboliczną istotę pogrzebu jako obrzędu przejścia (Reallexikon 1917-1923, s. 554-557 [hasło: Kamm]; Brückner 1927). Nie wykluczamy zatem, że w przyswojonej przez Słowian nazwie grzebienia należy domyślać się swoistej metonimii. Nazwa zjawiska o podłożu symboliczno-magicznym mogła bowiem zadecydować o nazwie przedmiotu używanego w obrzędach związanych $\mathrm{z}$ tymże zjawiskiem. Rozstrzygnięcie tegoż zagadnienia, o ile domysły nasze są trafne, pozostawić należy specjalistom.

W kontekście przywołanych uwag warto przypomnieć też o odnotowanym przez Galla Anonima (I.1-4, s. 11-16) szczególnym stosunku wczesnopiastowskiej elity 

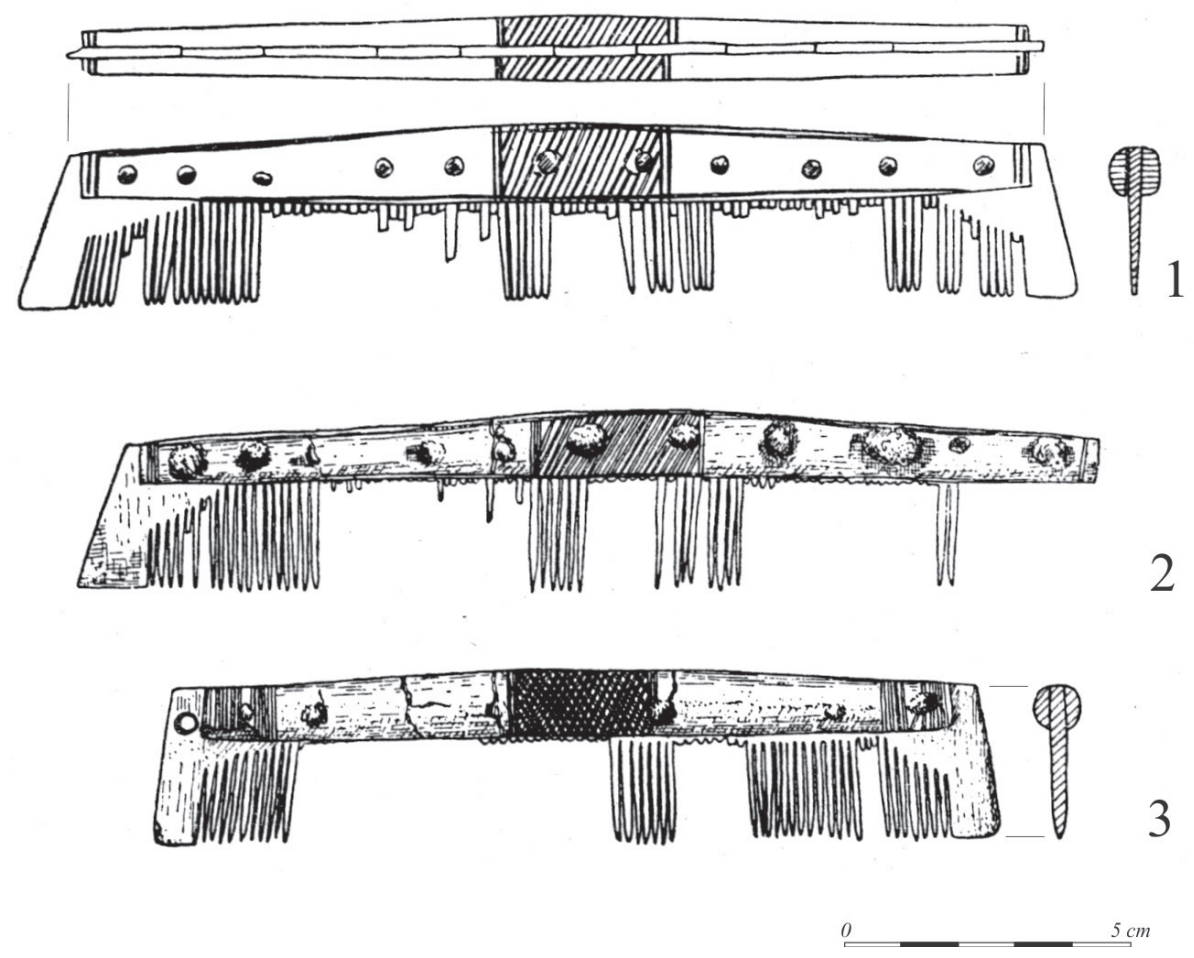

Ryc. 14. Wolin, stan. 1 (centrum osadnicze), gm. loco, woj. zachodniopomorskie. Wybór ornamentowanych grzebieni z poroża znalezionych w wykopie badawczym $\mathrm{nr} 4$, w warstwie nr XV z 4. ćwierci X w. Według Cnotliwy 1973, ryc. 39a-c (z modyfikacją). Przerys. J. Sawicka

do bujnych włosów męskich, jak również do obrzędu postrzyżyn dorastających chłopców. W pierwszym przypadku chodzi o znak władzy zwierzchniej - w sensie reges criniti władców merowińskich - w postaci „kosy”, to jest długich, specjalnie trefionych włosów, które należy traktować jako świadectwo podzielanej przez Słowian troski o szczególną pielęgnację głowy (por. Strzelczyk 1998, s. 55-56 [hasło: Chościsko], Banaszkiewicz 2010, s. 45 i n.). W przypadku postrzyżyn rzecz dotyczy „klasycznego” obrzędu przejścia o konotacjach sakralnych, wprowadzającego chłopców w świat dorosłych oraz w męskie struktury społeczne, jednocześnie zamykającego (uśmiercającego w sensie symboliki obciętych włosów) ich dotychczasowy etap życia, upływający pod kuratelą kobiet, i oddający postrzyżonego pod opiekę sił nadprzyrodzonych, w czym istotną rolę odgrywała znowu symbolika odciętych włosów, tym razem jako ofiary (Banaszkiewicz 2010, s. 143-174, zwłaszcza s. 173; przegląd starszych koncepcji zob. Gąsiorowski 1970, s. 249-250). Jakkolwiek uwagi Galla, zawarte w tzw. legendzie dynastycznej Piastów, odnoszą się 
wyłącznie do mieszkańców ówczesnej Polski, zwłaszcza do rodu panującego, aczkolwiek w przypadku księcia Mieszka I - tylko domyślnie, to jednak nie sposób wątpić, iż posiadały one szerszy kontekst słowiański.

$\mathrm{Z}$ poczynionymi ustaleniami nie kolidują wyniki analizy znaleziska ze Stroszek. Nie licząc odkrytego w środkowych Czechach - w m. Tursko koło Pragi - ekskluzywnego okazu typu IB-VIII-1 według E. Cnotliwego (Cnotliwy 1973, s. 152, przypis 199, ryc. 63:29; Sláma 1977, s. 165-167, nr 204C, ryc. 40:7), to jedyne - jak dotąd - najdalej na południe wysunięte znalezisko tego typu grzebieni, zlokalizowane poza granicą zwartego zasięgu ich występowania (ryc. 4). Z tego powodu, jak również ze względu na rodzaj pokrywającej grzebień ikonografii, dokonane w Stroszkach odkrycie ma charakter wyjątkowy.

Sądząc z materiałów archeologicznych stwierdzonych na osadzie w Stroszkach, zwłaszcza w obiekcie nr 164, omawiany przedmiot stanowił własność osoby wywodzącej się zapewne z miejscowego środowiska słowiańskiego, która powiązana była z osadniczo-funkcjonalnym okręgiem wczesnośredniowiecznego grodu w Gieczu. Jak już sygnalizowaliśmy, przemawia za tym położenie osiedla w niewielkiej odległości od wymienionego grodu - obiektu współczesnego osadzie, jednego z kilku ośrodków tzw. centralnych najstarszego władztwa Piastów.

Rysuje się możliwość przynależności właściciela/właścicielki rzeczonego grzebienia do wyznawców Chrystusa. Domysłu nie wyklucza symbolika ornamentyki tegoż przedmiotu, o czym już też wzmiankowaliśmy, jak również chronologia znaleziska (w 966 r. nastąpił chrzest księcia Mieszka - pierwszego historycznego władcy z rodu Piasta, zapewne z udziałem dworu i drużyny ${ }^{49}$ ). Wspiera go również odnotowane $w$ nauce zjawisko przenikania nowych idei oraz cywilizacyjno-kulturowych wzorców w obręb aglomeracji tzw. centralnych grodów wczesnopiastowskich, $\mathrm{z}$ czasem przekształconych $\mathrm{w}$ zespoły wczesnomiejskie, w związku z napływem ludności, także obcego pochodzenia (Kara 2009, s. 290 i n.; 2016, s. 100 i n.). W przypadku Giecza możliwa jest obecność wśród mieszkańców $\mathrm{X}$-wiecznej aglomeracji tegoż grodu przedstawicieli społeczności krajów nadbałtyckich, zwłaszcza ze Skandynawii i Rusi. Wskazują na to charakterystyczne ,importy" nagromadzone w nawarstwieniach stanowiska nr 4 w Gieczu w ilości niespotykanej $\mathrm{w}$ reliktach innych ośrodków grodowych tego czasu, przynajmniej w Wielkopolsce, które w Gieczu współwystępują z przyborami kupieckimi oraz srebrnymi monetami orientalnymi i zachodnioeuropejskimi, w tym z dirhemami emitowanymi w 1. połowie X w. przez emirów z dynastii Samanidów (zob. Krysztofiak 2007; 2013; 2015; 2016; b.r.w.).

Unikatowy charakter znalezionego w Stroszkach grzebienia - ekskluzywnego wyrobu kultury skandynawskiej z X w. - wskazuje na związek ,importu” z wy-

${ }^{49}$ Zob. Strzelczyk 1992, s. 97 i n. W toczonej obecnie dyskusji na temat miejsca i okoliczności chrztu wspomnianego władcy zdecydowanie opowiadamy się za koncepcją M. Matli (2017, s. 52) i T. Jasińskiego (2018), którzy ostrożnie lokalizują wspomniane wydarzenie w państwie Mieszka. 
mianą tzw. ceremonialną, która zasadzała się na emocjonalnych relacjach indywidulanych. Poprzez wzajemną, rytualną dystrybucję wyjątkowych towarów (zwykle o porównywalnych wartościach) strony zawiązywanej umowy (również w sensie pobratymstwa) honorowały się bez nadwątlenia prestiżu, utrwalając w ten sposób własny autorytet. Ceremonia podbudowywała jednocześnie zawierany kontrakt społeczny. Uzyskane przedmioty o wyjątkowym charakterze traktowano bowiem jako dary nasycone sakralną mocą, będące świadectwem dopełnienia uświęconych tradycją rytuałów i obrzędów (Gaul 1979; 1982; Markale 1988, s. 79; Dzieduszycki 1995, s. 64 i n.; A.P. Kowalski 1999; 2014, s. 219-230; Smith 2008, s. 175 i n.; Banaszkiewicz 2018c). W tym charakterze, jako znaki prestiżu, mogły być przechowywane przez członków rodu, mogły być przekazywane dalej, stanowiąc krążący między przedstawicielami elit ekskluzywny dar umacniający relacje społeczne, mogły też z powodu destrukcji być usuwane z obrębu ekumeny. (Przykładowo uszkodzony grzebień $\mathrm{z}$ osady w Stroszkach zalegał w zasypisku obiektu - opuszczonego bezpowrotnie domostwa - może jako swego rodzaju ofiara złożona „duchom” likwidowanego budynku przez jego właścicieli50). Miejsca ceremonialnej wymiany $\mathrm{w}$ przypadku interesującego nas grzebienia domyślamy się zarówno na ziemi gieckiej (patrz wymienione wyżej przesłanki świadczące za tą ewentualnością), jak i w którymś z rzemieślniczo-handlowych ośrodków nadbałtyckich, łącznie ze skandynawskim Hedeby, Birką czy Truso. Tego rodzaju obrzęd mógł finalizować interesy handlowe (np. zakup wysokiej jakości mieczów, por. Cnotliwy 2013, s. 79-82), mógł też wiązać pobratymstwo przedstawiciela gieckiej elity z wodzem drużyny wikińskiej. Wśród czynników sprzyjających nawiązaniu kontaktów międzyludzkich upatrujemy zbieżności mentalne łączące ówczesnych Słowian i Germanów, które przejawiały się w magiczno-mitycznym myśleniu o świecie, ukierunkowanym praktycznie. Przypuszczamy, że w przypadku milites o komunikacji społecznej decydowały również podzielane przez ludy „barbarzyńskiej" części Europy przekonania o honorze, odwadze i męstwie tudzież nieśmiertelnej sławie, jako wartościach najwyżej cenionych przez każdego wojownika.

W nawiązaniu do ostatnich uwag odnotujmy, że odkryty w Stroszkach grzebień wyraźnie wpisuje się w nurt odtworzonych przez archeologię przemian kulturowych, osadniczych i społecznych, które synchronizowane są z organizacyjnym procesem najstarszego państwa Piastów (Kurnatowska 2002, s. 60 i n.; 2008, s. 319 i n.; Kara 2009, s. 203 i n.; 2018). Odtworzony horyzont zjawisk kulturowych ujawnia zapożyczenia z kultury elit strefy nadbałtyckiej, po części też z elitarnej kultury strefy tzw. południowej (ściślej - naddunajskiej), która czerpała z dorobku Wielkich Moraw oraz cesarstwa Karolingów i Ottonów. Z istotnej dla naszych rozważań strefy nadbałtyckiej w granice ziemi gnieźnieńskiej trafiały m.in. ozdobne grzebienie uformowane z poroża.

\footnotetext{
${ }^{50}$ Obiekt nr 164 należał do młodszej (końcowej) fazy osiedla.
} 
Interesujący nas horyzont kulturowo-osadniczy, wyróżniony na ziemi gnieźnieńskiej i tożsamy z najstarszym horyzontem grodowym w tej części obecnej Wielkopolski, datowany jest $\mathrm{w}$ przedziale 1. połowa X-początek 2. połowy X w. (faza $\mathrm{D}_{0}$ wczesnego średniowiecza). Pobudowane $\mathrm{w}$ tym czasie warownie wyznaczają funkcjonalno-przestrzenną sieć złożoną z dwu segmentów grodów: tzw. poznańskiego na zachodzie i gnieźnieńsko-gieckiego (!) na wschodzie, która łącznie obejmowała obszar około $5000 \mathrm{~km}^{2}$, wyodrębniony prawobrzeżnymi dopływami środkowej Warty (ryc. 2). Należy podkreślić, że wszystkie grody wzniesiono nad ciekami bądź zbiornikami wodnymi połączonymi z Wartą, a grody w Poznaniu i Lądzie zbudowano w pobliżu brodów warciańskich położonych na przeciwległych peryferiach ziemi gnieźnieńskiej (Kara 2009 s. 282 i n.; 2016, s. 96 i n.). Kontrolowano $\mathrm{w}$ ten sposób dostęp $\mathrm{w}$ głąb wspomnianego terytorium zarówno od zachodu (Poznań), to znaczy od strony Pomorza Zachodniego (Nadodrzańskiego), Połabia i cesarstwa Ottonów oraz sąsiadującego z Czechami i Morawami Śląska, jak i od wschodu (Ląd), czyli od strony Mazowsza i Małopolski. Dodajmy, że w granicach Wysoczyzny Gnieźnieńskiej, począwszy od lat 40. X w. aż po stulecie XII, miała miejsce intensywna kumulacja srebrnego kruszcu (Kara 2018, s. 315, ryc. 3). Świadczą o tym skarby zakopywane w pobliżu współczesnych im grodów leżących nad wymienionymi ciekami, które pełniły wówczas funkcję arterii komunikacyjnych.

Akcentowane $\mathrm{w}$ ustaleniach archeologii znaczenie rzek oraz przepływowych jezior dla budowy pierwotnego patrimonium Piastów (obszar ich prymarnego władztwa oraz społecznej akceptacji, tożsamy z wyżej wymienionym terytorium grodowym) - jako szlaków transportu, włączonych w szerszy, transregionalny układ komunikacyjny - wiązało się również z uprawianiem przez tamtejsze wspólnoty rozwiniętej żeglugi śródlądowej (por. Kurnatowscy 1996; 2001; Kara 2016) (51 $^{51}$ Tłumaczy to naszym zdaniem wyraźną obecność „nadbałtyckich” grzebieni (w tym znaleziska ze Stroszek) w elitarnym nurcie kultury najstarszego państwa Piastów. Dodajmy, chodzi o najstarsze wczesnośredniowieczne znaleziska tego rodzaju przedmiotów w centralnej części obecnej Wielkopolski (Kara 2009), co pozwala domyślać się również funkcjonalnej adaptacji wspomnianych przyborów przez elity wczesnopiastowskie, mentalnie zbliżone do ówczesnych elit normańskich i ruskich. Jak bowiem trafnie skonstatował P. Brown (1991, s. 234): „Ludzie wczesnego średniowiecza [...] byli [...] pewni, że nad wszystkimi, którzy przestrzegają zwyczajów swych przodków, roztaczają opiekę - jak nad dzieckiem w kołysce - niewidzialni opiekunowie". Chcąc sprowokować ich do działania, sięgano m.in. po grzebień i czesano nim włosy.

51 W kwestii patrimonium podzielamy poglądy J. Banaszkiewicza (2015). Uważamy też, iż archeologia dysponuje metodą pozwalającą odtwarzać w rekonstrukcji dziejów państwa - w sensie organizmu kulturowego, osadniczego, gospodarczego i społecznego - zasięg oraz chronologię, jak również mechanizm formowania patrimonium rodu panującego. Nie jest to pogląd podzielany powszechnie. 


\section{BIBLIOGRAFIA}

\section{Źródła}

Beda Wielebny, Historia ludów Anglii; przekład i opracowanie H. Pietruszczak, Zgorzelec 2015.

Beowulf; przekład i opracowanie J.R.R. Tolkien, red. Ch. Tolkien; przekład na j. polski K. Staniewska „Elring”, A. Sylwanowicz „Evermind”, Warszawa 2015.

Biblia Tysiąclecia - Pismo Święte Starego i Nowego Testamentu w przekładzie z języków oryginalnych. Biblia Tysiaclecia; opracował zespół biblistów polskich z inicjatywy benedyktynów tynieckich, wyd. III, Poznań 1982.

Chronicon Lethtrense, w: Scriptores historiae Danicae minores, wyd. M. C. Gertz, København 1917.

Ebo, Żywot św. Ottona biskupa bamberskiego; wydanie krytyczne przygotował J. Wikarjak, wstęp i komentarz K. Liman; Monumenta Poloniae Historica, seria 2, t. 7, cz. 2, Warszawa 1969.

Snorri Sturluson, Edda; przekład na j. angielski i opracowanie A. Faulkes, London 1995.

Edda poetycka; przekład i opracowanie A. Załuska-Strömberg, Wrocław 1986.

Gall Anonim - Anonim tzw. Gall, Kronika polska; przekład R. Grodecki, opracowanie M. Plezia, wyd. 5, Wrocław 1982

Herodot, Dzieje, t. II; przekład i opracowanie S. Hammer, wyd. II, Warszawa 1959.

Ibn Faụlān, Kitāb-Księga (na podstawie Rękopisu meszhedzkiego), w: Źródła arabskie do dziejów Stowiańszczyzny, t. 3, opracowali A. Kmietowicz, F. Kmietowicz, T. Lewicki, Wrocław 1985.

Kronika królów z Lejre; przekład i opracowanie M. Janik, Sandomierz 2015.

Oddr Snorrason, Saga o Olafie Tryggvasonie; przekład i opracowanie A. Waśko, Kraków 2013.

Paweł Diakon, Historia Longobardów; przekład i opracowanie I. Lewandowski, Warszawa 1995.

Powieść minionych lat; przekład i opracowanie F. Sielicki, Wrocław 1999.

Saga o Egilu; przekład A. Załuska-Strömberg, posłowie G. Labuda, Poznań 1974.

Saga o Völsungach; przekład i opracowanie R. Leśniakiewicz, Sandomierz 2009.

Tacyt, Dzieje - Tacyt, Dzieła: Roczniki, Dzieje, Germania, Żywot Juliusza Agrykoli, Dialog o mówcach; przekład S. Hammer, wyd. 2, Warszawa 2004.

Tacyt, Germania - P. Cornelius Tacitus, Germania / Publiusz Korneliusz Tacyt, Germania; przekład T. Płóciennik, wstęp i komentarz J. Kolendo, Poznań 2008.

Thietmar - Kronika Thietmara; tekst łaciński i polski, przekład i opracowanie M.Z. Jedlicki, wyd. 1, Poznań 1953.

\section{Literatura}

Abramowicz A. 1962, Uwagi o roli hipotez w archeologii (na marginesie dyskusji K. Godtowskiego $z$ A. Gardawskim), „Prace i Materiały Muzeum Archeologicznego i Etnograficznego w Łodzi”, seria archeologiczna, nr 8, s. 103-114.

Adamus M. 1970, Tajemnice sag i run, Wrocław.

Ahrens C. (red.) 1978, Sachsen und Angelsachsen. Ausstellung des Helms-Museums Hamburgisches Museum für Vor- und Frühgeschichte 18. November 1978 bis 28. Februar 1979, Veröffentlichungen des Helms-Museums, nr 32, Hamburg.

Almgren B. 1980, Hjälmar, kronor och stridsrockar - från kejsargardets Rom till Upplands hövdingar, w: A. Sandwall (red.) 1980, s. 158-166.

Ambrosiani B. 1981, Birka, w: L. Thunmark-Nylén (red.) 1981, s. 22-24.

Ambrosiani K. 1981, Viking Age Combs, Comb Making and Comb Makers in the Light of Finds from Birka and Ribe, Stockholm Studies in Archaeology, t. 2, Stockholm.

- 1984, Kämme, w: G. Arwidsson (red.) 1984, s. 161-176.

Androshchuk F. 2007, The Rural Vikings and the Viking Helgö, w: U. Fransson, M. Svedin, S. Bergerbrant, F. Androshchuk (red.) 2007, s. 153-163.

Arbman H. 1940, Birka, t. I: Die Gräber. Tafeln, Uppsala. 
- 1943, Birka, t. I: Die Gräber. Text, Uppsala.

- 1944, Hornsnidare som konstnärer, „Situne Dei”, t. 3, s. 7-20.

Arwidsson G. (red.) 1984, Birka, t. II:1: Systematische Analysen der Gräberfunde, Stockholm.

Ashby S.P. 2007, Bone and Antler Combs, w: The Finds Research Group AD 700-1700. Datasheets, t. 2, FRG 40.

- 2009, Combs, Contact and Chronology: Reconsidering Hair Combs in Early-Historic and Viking-Age Atlantic Scotland, „Medieval Archaeology”, t. 53, s. 1-33.

- 2010, A Typological Guide for the Spot-Identification of Medieval Bone / Antler Combs from the British Isles and Northern Europe, Unpublished Datasheet of the ICAZ Worked Bone Research Group; źródło internetowe (dostęp: 23.05.2019): http://www.wbrg.net/images/stories/typology/ashby_comb_typology_2010.pdf.

- 2011, An Atlas of Medieval Combs from Northern Europe, „Internet Archaeology”, nr 30; źródło internetowe (dostęp: 23.05.2019): https://doi.org/10.11141/issn.1363-5387.

- 2013, Making a good comb: mercantile identity in 9th- to 11th-century England, w: D.M. Hadley, L. ten Harkel (red.), Everyday Life in Viking-Age Towns. Social Approaches to Towns in England and Ireland, c. 800-1100, Oxford, s. 193-208.

Ashby S.P., Batey C.E. 2012, Evidence of Exchange Networks: the Combs and other Worked Skeletal Material, w: J.H. Barrett (red.), Being an Islander: Production and Identity at Quoygrew, Orkney AD 900-1600, Cambridge, s. 229-243.

Banaszkiewicz J. 2010, Podanie o Piaście i Popielu. Studium porównawcze nad wczesnośredniowiecznymi tradycjami dynastycznymi, wyd. 2 (poszerzone), Warszawa.

- 2015, Parę uwag bardzo ogólnych o problematyce poznańskiej debaty nad początkami ,wczesnych państw”, w: J. Banaszkiewicz, M. Kara, H. Mamzer (red.), Instytucja „,wczesnego państwa” w perspektywie wielości i różnorodności kultur, wyd. 2 (poprawione), Poznań, s. 425-430.

- 2016, Giecz na Gallowej liście wielkich grodów Bolestawa Chrobrego, w:

M. Kara, T. Krysztofiak, A.M. Wyrwa (red.) 2016, s. 75-90.

- 2018a, Rodulf, król Herulów, który grat (Pawet Diakon, Hist. Long., I, 20), w: J. Banaszkiewicz 2018b, s. 264-275.

- 2018b, W stronę rytuatów i Galla Anonima, Kraków.

- 2018c, Zlota ręka komesa Żelisława (Gall, II, 25; Kadtubek, II, 24, 26), w: J. Banaszkiewicz 2018b, s. 210-243.

Banek K. 2010, Opowieść o wlosach. Zwyczaje - rytuaty - symbolika, Warszawa.

Barthes R. 1970, Mit i znak. Eseje, Warszawa.

- 2009, Podstawy semiologii, Kraków.

Bates B. 2005, Magia, mity i tajemnice średniowiecza, Warszawa.

Bertram M. 2002, Die frühmittelalterlichen Gräberfelder von Pocking-Inzing und Bad ReichenhallKirchberg. Rekonstruktion zweier Altgrabungen, Museum für Vor- und Frühgeschichte, Staatliche Museen zu Berlin, Bestandskataloge, t. 7, Berlin.

Bieniak J. 1963, Rola Kujaw w Polsce Piastowskiej, „Ziemia Kujawska”, t. 1, s. $27-71$.

Brandt K., Müller-Wille M., Radtke Ch. (red.) 2002, Haithabu und die frühe Stadtentwicklung

im nördlichen Europa, Schriften des Archäologischen Landesmuseums Schloß Gottorf, t. 8, Neumünster.

Brather S. 2010 (2015), The early medieval emporium Janów Pomorski (Truso). Characteristics and comparison based on excavations 2004-2008, „Archaeologia Polona”, t. 48, s. 229-243.

Brown P. 1991, Świat późnego antyku. Od Marka Aureliusza do Mahometa, Warszawa.

Brøndsted J. 1936, Danish Inhumation Graves of the Viking Age. A Survey, „Acta Archaeologica”, t. 7, s. $81-228$.

Brückner A. 1927, Stownik etymologiczny języka polskiego, Kraków.

Brzostowicz M. 1996, Grzebień rogowy z osady wczesnośredniowiecznej w Stroszkach, gm. Nekla, woj. poznańskie, stanowisko 1, w: Z. Kurnatowska (red.) 1996, s. 269-274.

Buchholz H.G. 1984-1985, Ägäische Kämme, „Acta Praehistorica et Archaeologica”, t. 16-17, s. 91-142.

Buko A. (red.) 2016, Bodzia. Elitarny cmentarz z początków państwa polskiego, Warszawa.

Burszta W. 1987a, Etnonauka, w: Z. Staszczak (red.) 1987, s. 105-107.

- 1987b, Strukturalizm, w: Z. Staszczak (red.) 1987, s. 331-334. 
Callmer J. 1995, Handwerksproduktion, Gesellschaftsveränderungen und Besiedlung.

Betrachtungen aus Südost-Skandinavien von ca. 600 bis 1100 n. Chr., „Ethnographisch-Archäologische Zeitschrift", t. 36, nr 1, s. 100-124.

- 1997, Aristokratiskt präglade residens från yngre järnåldern i forskningshistorien och deras problematik, w: J. Callmer, E. Rosengren (red.) 1997, s. 11-18.

- 1998, Archaeological Sources for the Presence of Frisian Agents of Trade in Northern Europe ca. $A D$ 700-900, w: A. Wesse (red.) 1998, s. 469-481.

Callmer J., Rosengren E. (red.) 1997, „...Gic Grendel att söka det höga huset...”. Arkeologiska källor till aristokratiska miljöer i Skandinavien under yngre järnålder, Rapport från ett seminarium i Falkenberg 16-17 november 1995, Slöinge Projektet, t. 1, Halmsta.

Chapeaurouge D. de 2014, Symbole chrześcijańskie, Kraków.

Christensen T. 1991, Lejre Beyond Legend - The Archaeological Evidence, „Journal of Danish Archaeology", t. 10, s. 163-185.

Chudziak W. 2009, Wyspa w Żóltym na Jeziorze Zarańskim - na pograniczu rzeczywistości i transcendencji, w: T. Sawicki (red.), Studia nad dawna Polska, t. 2, Gniezno, s. 47-70.

Chudziak W., Pranke P., Kaźmierczak R. 2014, Socio-cultural functions of the island in Żółte, w: W. Chudziak, R. Kaźmierczak (red.), The Island in Żółte on Lake Zarańskie. Early Medieval Gateway into West Pomerania, Toruń, s. 441-450.

Cirlot J.E. 2007, Stownik symboli, Kraków.

Clarke D., Heald A. 2002, Beyond Typology: Combs, Economics, Symbolism and Regional Identity in Late Norse Scotland, „Norwegian Archaeological Review”, t. 35, nr 2, s. 81-93.

Clarke H., Lamm K. 2017, Helgö Revisited. A new look at the excavated evidence for Helgö, central Sweden, Schleswig.

Cnotliwy E. 1973, Rzemiosło rogownicze na Pomorzu wczesnośredniowiecznym, Wrocław.

- 1993 (1994), Uwagi o rzemiośle rogowniczym w strefie nadbaltyckiej w VII-XIII wieku, „Archeologia Polski”, t. 38, nr 2, s. 337-369.

- 2013, Przedmioty z poroża i kości z Janowa Pomorskiego, w: M. Bogucki, M.F. Jagodziński (red.), Studia nad Truso / Truso Studies, t. 2, Elbląg, s. 13-181.

Cnotliwy E., Łosiński W. 1995, Szczecin/Stettin. Vom frühstädtischen Zentrum zur Lokationsstadt, „Slavia Antiqua", t. 36, s. 73-92.

Cnotliwy E., Łosiński W., Wojtasik J. 1986, Rozwój przestrzenny wczesnośredniowiecznego Wolina $w$ świetle analizy porównawczej struktur zespołów ceramicznych, w: J. Gromnicki (red.), Problemy chronologii ceramiki wczesnośredniowiecznej na Pomorzu Zachodnim, Studia i Materiały PKZ, Warszawa, s. 62-117.

Černych N.B. 1985, Dendrochronologija drevnejšich gorizontov Ladogi (po materialam raskopok Zemljanogo gorodišča), w: V.V. Sedov (red.) 1985, s. 76-80.

Dobosz J., Strzelczyk J., Matla M. (red.) 2016, Chrystianizacja „Młodszej Europy”, Uniwersytet im. Adama Mickiewicza w Poznaniu, seria Historia, nr 228, Poznań.

Duczko W. 1997, Gamla Uppsala - svearnas maktcentrum $i$ äldre och nyare forskning, w: J. Callmer, E. Rosengren (red.) 1997, s. 71-81.

- 2006, Ruś Wikingów. Historia obecności Skandynawów we wczesnośredniowiecznej Europie Wschodniej, Warszawa.

Duczko W. (red.) 1996, Arkeologi och miljögeologi i Gamla Uppsala. Studier och rapporter, t. 2, Occasional Papers in Archaeology, t. 11, Uppsala.

Dumézil B. 2008, Chrześcijańskie korzenie Europy. Konwersja i wolność w królestwach barbarzyńskich od V do VIII wieku, Kęty.

Düwel K. 1986, Zur Ikonographie und Ikonologie der Sigurddarstellungen, w: H. Roth (red.) 1986, s. 221-271.

Dymaczewska U., Dymaczewski A. 1967, Wczesnośredniowieczny Santok. Wyniki badań wykopaliskowych we wnętrzu grodu w latach 1958-1961, „Slavia Antiqua”, t. 14, s. 185-241.

Dzieduszycki W. 1995, Kruszce w systemach wartości i wymiany społeczeństwa Polski wczesnośredniowiecznej, Poznań.

Eliade M. 1998, Mit wiecznego powrotu, Warszawa. 
Ellmers D. 1964/1965, Zum Trinkgeschirr der Wikingerzeit, „Offa”, t. 21/22, s. 21-43.

- 1986, Schiffsdarstellungen auf skandinavischen Grabsteinen, w: H. Roth (red.) 1986, s. 341-372.

- 1998, Fischhandel, Fischereifahrzeuge und ihre Besatzungen auf Bilddenkmälern der Vendel- und Wikingerzeit, w: A. Wesse (red.) 1998, s. 483-495.

Evans A.C. 1989, The Sutton Hoo Ship Burial, London.

Fabech Ch. 1997, Slöinge i perspektiv, w: J. Callmer, E. Rosengren (red.) 1997, s. 145-160.

Fransson U, Svedin M., Bergerbrant S., Androshchuk F. (red.) 2007, Cultural interaction between east and west. Archaeology, artefacts and human contacts in northern Europe, Stockholm.

Frutaz A.P. 1952, Pettine, w: Enciclopedia Cattolica, t. 9, Città del Vaticano, kolumna 1305-1306.

Gadamer H.G. 1993, Prawda i metoda. Zarys hermeneutyki filozoficznej, Kraków.

Gałęzowska A. 2005, Osady kultur pomorskiej, przeworskiej $i$ wielbarskiej w Stroszkach w powiecie wrzesińskim, „Fontes Archaeologici Posnanienses”, t. 40, s. 281-454.

Gansum T. 2003, Hår og stil og stilig hår: Om langhåret maktsymbolikk, „Universitetets kulturhistoriske museer. Oslo", skrifter nr 2: Snartemofunnene i nytt lys, s. 191-221.

Gaul J. 1979, Upieniężnienie wymiany w zachodniej części strefy battyckiej w 2 połowie V-VI w. n.e., „Wiadomości Numizmatyczne”, t. 23, nr 2 (88), s. 69-86.

- 1982, Pochodzenie a obieg złota u schytku starożytności w strefie zachodniobattyckiej, „Wiadomości Numizmatyczne", t. 26, nr 1-2 (99-100), s. 48-54.

Gąsiorowski A. 1970, Postrzyżyny, w: G. Labuda, Z. Stieber (red.), Stownik Starożytności Stowiańskich. Encyklopedyczny zarys kultury Stowian od czasów najdawniejszych do schyłku wieku XII, t. 4, nr 1, Wrocław, s. 249-250.

Giesler J. 2006, Die fränkische Grabstele von Niederdollendorf, w: T. Otten, S. Ristow (red.), Von den Göttern zu Gott. Frühes Christentum im

Rheinland - Katalogbuch zur Ausstellung im Rheinischen LandesMuseum Bonn des Landschaftsverbandes Rheinland (14.12.2006-15.04.2007), Tübingen, s. 106-107.

Górecki J. 2000, Rzeźbiony grzebień z Ostrowa Lednickiego. Próba interpretacji, „Studia Lednickie”, t. 6 , s. 13-44.

Gräslund A.S. 1980, Birka, t. IV: The Burial Customs. A study of the graves on Björkö. Stockholm.

- 1983-1985, Den tidiga missionen i arkeologisk belysning - problem och synpunkter, „Tor”, t. 20, s. 291-313.

- 2001, Ideologi och Mentalitet. Om religionsskiftet i Skandinavien från en arkeologisk horisont, Occasional Papers in Archaeology, t. 29, Uppsala.

- 2007, Some Viking-age Amulets - the Birka Evidence, w: U. Fransson, M. Svedin, S. Bergerbrant, F. Androshchuk (red.) 2007, s. 90-96.

Grimm O., Pesch A. (red.) 2011, The Gudme / Gudhem Phenomenon, Schriften des Archäologischen Landesmuseums Schloss Gottorf. Ergänzungsreihe, t. 6, Neumünster.

Gustin I. 2004, Mellan gåva och marknad. Handel, tillit och materiell kultur under vikingatid, Lund Studies in Medieval Archaeology, t. 34, Malmö.

Hamerow H. 2010, Herrenhöfe in Anglo-Saxon England, w: Herrenhöfe... 2010, s. 275-283.

Hauck K. 1984, Formenkunde der Götterthrone des heidnischen Nordens. (Zur Ikonologie der Goldbrakteaten, XXIX), „Offa”, t. 41, s. 29-39.

- 1986, Methodenfragen der Brakteatendeutung. Erprobung eines Interpretationsmusters für die Bildzeugnisse aus einer oralen Kultur. (Zur Ikonologie der Goldbrakteaten, XXVI), w: H. Roth (red.) 1986, s. 273-296.

Hägg I. 2002, Aussagen der Textilfunde zu den gesellschaftlichen und wirtschaftlichen Verhältnissen frühstädtischer Zentren in Nordeuropa - die Beispiele Haithabu und Birka, w: K. Brandt, M. Müller-Wille, Ch. Radtke (red.) 2002, s. 181-218.

- 2007, Some Archaeological Aspects of Christian and Pagan Symbols in the Period of Christianisation, w: U. Fransson, M. Svedin, S. Bergerbrant, F. Androshchuk (red.) 2007, s. 101-106.

Hårdh B. 2000, Uppåkra - a centre in south Sweden in the 1st millennium AD, „Antiquity”, t. 74, nr 285, s. $640-648$.

Hårdh B., Larsson L. (red.) 2002, Central Places in the Migration and Merovingian Periods. Papers from the 52nd Sachsensymposium Lund, August 2001, Uppåkrastudier 6, Acta Archaeologica Lundensia, series in $8^{\circ}, \mathrm{nr} 39$, Lund. 
Hedeager L. 1998, Cosmological Endurance: Pagan identities in Early Christian Europe, „European Journal of Archaeology", t. 1, nr 3, s. 382-396.

- 2001, Asgard Reconstructed? Gudme - a 'Central Place' in the North, w: M. de Jong, F. Theuws, C. van Rhijn (red.), Topographies of Power in the Early Middle Ages, Leiden, s. 467-507.

- 2002, Scandinavian 'Central Places' in a Cosmological Setting, w: B. Hårdh, L. Larsson (red.) 2002, s. 3-18.

Hedenstierna-Jonson C., Holmquist Olausson L. 2006, The Oriental Mounts from Birka's Garrison. An expression of warrior rank and status, Antikvariskt arkiv 81, Stockholm.

Hedenstierna-Jonson C. i in. (Hedenstierna-Jonson C., Kjellström A., Zachrisson T., Krzewińska M., Sobrado V., Price N., Günther T., Jakobsson M., Götherström A., Storå J.) 2017, A female Viking warrior confirmed by genomics, „American Journal of Physical Anthropology”, t. 164, s. 853-860.

Helmbrecht M. 2011, Wirkmächtige Kommunikationsmedien. Menschenbilder der Vendel- und Wikingerzeit und ihre Kontexte, Acta Archaeologica Lundensia, series Prima in $4^{\circ}, \mathrm{nr} 30$, Lund.

Helmers M. 1939, Zur Deutung der Ornamentik auf einer Amphore der Walternienburger Keramik, „Mannus”, t. 31, nr 2, s. 225-230.

Henderson G. 1987, Wczesne Średniowiecze, Warszawa.

Hensel W., Hilczer-Kurnatowska Z. 1987, Studia i materialy do osadnictwa Wielkopolski wczesnohistorycznej, t. 6, Wrocław.

Herrenhöfe... 2010 - Herrenhöfe und Hierarchie der Macht im Raum südlich und östlich der Nordsee von der Vorrömischen Eisenzeit bis zum frühen Mittelalter und zur Wikingerzeit / Herrenhöfe and the Hierarchy of Power in the Region to the South and East of the North Sea from the Pre-Roman Iron Age until the Early Middle Ages and the Viking Age. Gedächtnis-Kolloquium / Memorial Colloquium Werner Haarnagel (1907-1984), 11.-13. Oktober 2007, Burg Bederkesa in Bad Bederkesa, Siedlungs- und Küstenforschung im südlichen Nordseegebiet / Settlement and Coastel Research in the Southern North Sea Region, t. 33, Rahden/Westf.

Herrmann J. 2003 (2004), Seehandelsplätze des 8. Jahrhunderts an der südwestlichen Ostseeküste und deren slawisches Hinterland. Eine Problemsicht, „Bodendenkmalpflege in Mecklenburg-Vorpommern", t. 51, s. 437-448.

Higham N.J., Ryan M.J. 2013, The Anglo-Saxon World, London.

Hilczerówna Z. 1961, Rogownictwo gdańskie w X-XIV wieku, w: J. Kamińska (red.), Gdańsk wczesnośredniowieczny, t. 4, Gdańsk, s. 41-144.

Holst S., Jørgensen L., Wamers E. 2017, Odin, Thor und Freyja. Skandinavische Kultplätze des 1. Jahrtausends n. Chr. und das Frankenreich. Eine Ausstellung des Archäologischen Museums Frankfurt und des Dänischen Nationalmuseums Kopenhagen, Regensburg.

Hope-Taylor B. 2009, Yeavering. An Anglo-British centre of early Northumbria, Swindon.

Horbowicz P. i in. (Horbowicz P., Kreutzer G., Maciejewski W., Skrzypek D.) 2011, Runy, Acta Sueco -Polonica, Monografie 2, Warszawa.

Informator Archeologiczny 1983. Badania rok 1982, Warszawa.

Informator Archeologiczny 1985. Badania rok 1984, Warszawa.

Informator Archeologiczny 1986. Badania rok 1985, Warszawa.

Informator Archeologiczny 1987. Badania rok 1986, Warszawa.

Iversen M., Näsman U., Vellev J. (red.) 1991, Mammen. Grav, kunst og samfund i vikingetid, Jysk Arkæologisk Selskabs Skrifter, t. 28, Aarhus.

Jagodziński M.F. 2010, Truso. Między Weonodlandem a Witlandem / Truso. Between Weonodland and Witland, Elbląg 2010.

Jakimowicz A. 1967, Sztuka Indii. Szkice, Warszawa.

Jankuhn H. 1943, Die Ausgrabungen in Haithabu (1937-1939). Vorläufiger Grabungsbericht, BerlinDahlem.

Janowski A. 2014, $W$ wolińskim porcie... / In Wolin's port..., Wolin.

- 2015, Groby komorowe w Europie Srodkowo-Wschodniej. Problemy wybrane, Szczecin.

Jansson I. 1992, Freyr-Statuette (Rällinge, Lunda Ksp., Södermanland, Schweden), w: Wikinger... 1992, s. 276, nr 182.

Jansson S.B.F. 1957, Ett nyfunnet öländskt runbleck, „Fornvännen”, t. 52, s. 74-76. 
Jasiński T. 2018, Historyczne aspekty Christianitatis w początkach polskiej państwowości, w: A. Stempin (red.), Blask Christianitatis. Akademia Genius loci - zapis zgromadzonych materiałów (album wystawy), Poznań, s. 63-69.

Jażdżewski K. 1967, Tabele chronologiczne do pradziejów Europy środkowej i środkowo-wschodniej (w szczególności Polski) / Chronologische Tabellen zur Urgeschichte Mittel- und Mittel-Ost-Europas (im besonderen Polens), „Prace i Materiały Muzeum Archeologicznego i Etnograficznego w Lodzi”, seria archeologiczna, nr 14, s. 5-28.

Jażdżewski K., Kamińska J., Gupieńcowa R. 1966, Le Gdańsk des X'e-XIII siècles, w: W. Hensel (red.), Archaeologia urbium, t. 1, Warszawa.

Jensen B. 2013, Chronospecificities: Period-Specific Ideas about Animals in Viking Age Scandinavian Culture, „Society \& Animals”, t. 21, s. 208-221.

Józefowiczówna K. 1963, Z badań nad architektura przedromańska i romańska w Poznaniu, Polskie badania archeologiczne, t. 9, Wrocław.

Jöns H., Kowalska A.B. 2018, Z badań nad obecnościa Skandynawów na poludniowym wybrzeżu Bałtyku w poczatkach średniowiecza, „Slavia Antiqua”, t. 59, s. 121-130.

Jørgensen L. 2005, Tissø, w: R. Müller (red.), Reallexikon der Germanischen Altertumskunde von Johannes Hoops, t. 30, wyd. II, Berlin, s. 619-624.

- 2009, Pre-Christian cult at aristocratic residences and settlement complexes in southern Scandinavia in the $3^{r d}-10^{\text {th }}$ centuries $A D$, w: U. von Freeden, H. Friesinger,

E. Wamers (red.), Glaube, Kult und Herrschaft. Phänomene des Religiösen im 1. Jahrtausend n. Chr. in Mittel- und Nordeuropa, Akten des 59. Internationalen Sachsensymposions und der Grundprobleme der frühgeschichtlichen Entwicklung im Mitteldonauraum, Bonn, s. 329-354.

Kara M. 2006a, Nowe w archeologii Wielkopolski wczesnośredniowieczne - 15 lat później, w: W. Chudziak, S. Moździoch (red.), Stan i potrzeby badań nad wczesnym średniowieczem w Polsce - 15 lat później, Toruń, s. 207-244.

- 2006b, W kwestii pochodzenia wczesnośredniowiecznych osetek z fyllitu odkrytych na ziemiach Polski pótnocno-zachodniej-glos w dyskusji, w: M. Dworaczyk,

A.B. Kowalska, S. Moździoch, M. Rębkowski (red.), Świat Słowian wczesnego średniowiecza, Szczecin, s. $395-404$

- 2009, Najstarsze państwo Piastów - rezultat przełomu czy kontynuacji? Studium archeologiczne, Poznań.

- 2010 (2015), Medieval historical studies and medieval archaeology about the origin of the Piast State. An overview, „Archaeologia Polona”, t. 48, s. 37-58.

- 2015, Kultura elitarna mieszkańców grodu w Santoku we wczesnym średniowieczu na podstawie materiałów archeologicznych z wykopu II (ar 297). Opracowanie naukowe (mps w IAE PAN w Poznaniu; praca wykonana w związku z projektem NPRH nr 11H 110184 80/2012-2017, kierowanym przez Z. Hilczer-Kurnatowską i K. Zamelską-Monczak).

- 2016a, Organizacja przestrzeni grzebalnej, rytuat i obrzadek pogrzebowy, w: A. Buko (red.) 2016, s. 329-380.

- 2016b, Relikty osadnictwa ze starszych faz wczesnego średniowiecza oraz przełomu faz starszych i młodszych (od około VI/VII do pierwszej połowy XI w.) z obszaru obecnej tzw. matej aglomeracji miasta Poznania. Próba zarysu przemian osadniczych wedlug nowszych ustaleń archeologii, w: M. Kara, M. Makohonienko, A. Michałowski, Przemiany osadnictwa i środowiska przyrodniczego Poznania i okolic od schytku starożytności do lokacji miasta, Poznań s. 71-132.

- 2016c, Uzbrojenie, w: A. Buko (red.) 2016, s. 115-130.

- 2017, Multidyscyplinarna konferencja naukowa w Poznaniu ,, Od archeologii Józefa Kostrzewskiego do wspótczesnych nauk o przeszłości społecznej”. Przegląd poruszonej problematyki, „Slavia Antiqua", t. 58, s. $179-188$.

- 2018, Transformations of Elite Culture in Wielkopolska Related to the Process of the Piast State Formation (with a Particular Emphasis on Strongholds). An Archaeological Perspective, w: P. Kouřil, R. Procházka i in., Moravian and Silesian Strongholds of the Tenth and Eleventh Centuries in the Context of Central Europe, Spisy Archeologického ústavu AV ČR Brno, t. 57 , Brno, s. 307-318. 
Kara M., Krysztofiak T., Wyrwa A.M. (red.) 2016, Gród piastowski w Gieczu. Geneza - funkcja - kontekst, Poznań.

Kasperski R. 2017a, Kilka uwag o dwóch opowieściach o zwycięstwie Longobardów nad Herulami (Pawet Diakon, Historia Longobardorum, I, 20 i Prokopiusz z Cezarei, De Bellis, VI, 14), „Studia Źródłoznawcze", t. 55, s. 11-25.

- 2017b, Reges et gentes. Studia nad dyskursem legitymizującym władzę nad wspólnotami wyobrażonymi oraz strategiami ich konstruowania we wczesnym średniowieczu (VI-VII w.), Warszawa.

Kempiński A.M. 2001, Encyklopedia mitologii ludów indoeuropejskich, Warszawa.

- 2003, Ilustrowany leksykon mitologii wikingów, Poznań.

Kleingärtner S. 2014, Die frühe Phase der Urbanisierung an der südlichen Ostseeküste im ersten nachchristlichen Jahrtausend, Studien zur Siedlungsgeschichte und Archäologie der Ostseegebiete, t. 13, Neumünster.

Kmietowicz A., Kmietowicz F., Lewicki T. 1985, Źródła arabskie do dziejów Słowiańszczyzny, t. 3, Wrocław.

Kmita J. 1982, O kulturze symbolicznej, Warszawa.

- 1989, Dziedzictwo magii w nauce, w: H. Kozakiewicz, E. Mokrzycki, M.J. Siemek (red.), Racjonalność - nauka - spoleczeństwo, Warszawa, s. 50-66.

Kondrat'eva O.A. 1999, „Jazyk grebnja”. K. voprosu o semiotičeskom statuse vešči, w: E.N. Nosov (red.) 1999, s. 80- 88.

Kopaliński W. 1990 (1991), Stownik symboli, Warszawa.

Kościński B., Paner H. 2005, Nowe wyniki datowania grodu gdańskiego. Stanowisko 1, wykopy I-V, w: R. Barnycz-Gupieniec, Planigrafia materialu zabytkowego z osady podgrodowej wczesnośredniowiecznego Gdańska (stanowisko 1), Gdańsk, s. 9-12.

Kowalska A.B., Dworaczyk M. 2011, Szczecin wczesnośredniowieczny. Nadodrzańskie centrum, Origines Polonorum, t. 5, Warszawa.

Kowalska M. 1998, O rytualnym charakterze sztuki ludności kultury pomorskiej, „Pomorania Antiqua”, t. 17 , s. $31-54$.

Kowalski A.P. 1998, Estetyczne problemy badań nad ikonografia prahistoryczna. Przyklad sztuki tzw. kultury pomorskiej, „Pomorania Antiqua”, t. 17, s. 55-78.

- 1999, Dar, import i obcość. Szkic z prahistorycznej etnologii kontaktu kulturowego, w: S. Kukawka (red.), Szkice prahistoryczne. Źródła - metody - interpretacje, Toruń, s. 13-32.

- 2014, Antropologia zamierzchlych znaczeń, Toruń.

Kowalski P. 1998, Leksykon. Znaki świata. Omen, przesąd, znaczenie, Warszawa.

Kóčka-Krenz H. 2008, Najstarszy Poznań - wcią̇ odkrywany, w: T. Sawicki (red.), Studia nad dawna Polska, t. 1, Gniezno, s. 35-53.

Kóčka-Krenz H., Kara M., Makowiecki D. 2004, The Beginnings, Development and the Character of the Early Piast Stronghold in Poznan, w: P. Urbańczyk (red.), Polish Lands at the Turn of the First and the Second Millennia, Warsaw, s. 125-166.

Krantz R. 1972, Structures de la Mythologie Nordique, Paris.

Krąpiec M., Krysztofiak T. 2003, Potwierdzenie plemiennej genezy grodu w Gieczu, „Wielkopolskie Sprawozdania Archeologiczne", t. 6, s. 32-51.

Krysztofiak T. 2007, Rozwój wczesnośredniowiecznego ośrodka grodowego w Gieczu w świetle źródeł archeologicznych, w: A. Grygorowicz, K. Milecka, K. Tobolski (red.), Architektoniczno-przestrzenne i przyrodnicze podstawy rekonstrukcji wczesnośredniowiecznych zatożeń obronnych Giecza, Poznań, s. $15-39$.

- 2009, Giecz. Gródek przedpaństwowy - wczesnopiastowski gród centralny - ośrodek kasztelański, w: A.M. Wyrwa (red.), Custodia Meomoriae. Muzeum Pierwszych Piastów na Lednicy. XL lat istnienia (1969-2009), Lednica, s. 111-139.

- 2013, Okucie ze znakiem Ruryka znalezione w Gieczu, „Archeologia Polski”, t. 58, nr 1-2, s. 115-127.

- 2015, Stanowisko nr 4 w Gieczu w świetle badań archeologicznych, w: T. Krysztofiak, A.M. Wyrwa (red.), Monety ze stanowiska $n r 4$ w Gieczu, t. 1, Fontes. Biblioteka Studiów Lednickich, seria B1, t. 6:1, Lednica, s. 17-57. 
- 2016, Ośrodek grodowy w Gieczu w okresie przed- i wczesnopaństwowym, w: M. Kara, T. Krysztofiak, A.M. Wyrwa (red.) 2016, s. 115-154.

- b.r.w., Terra Sancta. Giecz w monarchii piastowskiej. Przewodnik - stała wystawa muzealna, Giecz. Kubiak Z. 1997, Mitologia Greków i Rzymian, Warszawa.

Kucypera P., Wadyl S. 2012, Kultura materialna, w: S. Tabaczyński i in. (red.) 2012, s. 614-626.

Kulesza P. 2007, Normanowie a chrześsijaństwo. Recepcja nowej wiary w Skandynawii w IX i X wieku, Wrocław.

Kurnatowscy Z. i S. 1996, Znaczenie komunikacji wodnej dla spoteczeństw pradziejowych $i$ wczesnośredniowiecznych w Polsce, w: Z. Kurnatowska (red.) 1996, s. 117-123.

- 2001, Rola szlaków komunikacyjnych w wykreowaniu i dalszym rozwoju wczesnopaństwowych ośrodków stotecznych, w: E. Wilgocki, M. Dworaczyk, K. Kowalski, A. Porzeziński, S. Słowiński (red.), Instantia est Mater Doctrinae. Księga jubileuszowa Prof. dr. hab. Władystawa Filipowiaka, Szczecin, s. 93-100.

Kurnatowska Z. 2002, Początki Polski, Poznań.

- 2008, Początki i rozwój państwa, w: M. Kobusiewicz (red.), Pradzieje Wielkopolski. Od epoki kamienia do średniowiecza, Poznań, s. 297-395.

Kurnatowska Z. (red.) 1996, Stowiańszczyzna w Europie średniowiecznej, t. I: Plemiona i wczesne państwa, Wrocław.

Kurnatowska Z., Kara M. 2004, Poczatki architektury sakralnej na grodzie poznańskim $w$ świetle nowych ustaleń archeologicznych, w: T. Janiak, D. Stryniak (red.), Poczatki architektury monumentalnej w Polsce. Materialy z sesji naukowej Gniezno, 20-21 listopada 2003 roku, Gniezno, s. 47-70.

- 2010, Wczesnopiastowskie regnum - jak powstato i jaki miało charakter? Próba spojrzenia od strony źródet archeologicznych, „Slavia Antiqua”, t. 51, s. 23-96.

Kurnatowska Z., Kurnatowski S. 2012, Parę uwag o odkrywaniu rzeczywistości kulturowej poprzez źródta archeologiczne, w: A. Pleszczyński, J. Sobiesiak, M. Tomaszek,

P. Tyszka (red.), Historia Narrat. Studia mediewistyczne ofiarowane Profesorowi Jackowi Banaszkiewiczowi, Lublin s. 21-64.

Kurnatowska Z., Łosińska A. 1990 (1992), Stan i potrzeby badań nad wczesnym średniowieczem w Wielkopolsce, w: Z. Kurnatowska (red.), Stan i potrzeby badań nad wczesnym średniowieczem w Polsce, Materiały z konferencji Poznań 14-16 grudnia 1987 roku, Poznań, s. 105-153.

Kwapiński M. 1998, Paradoks Monteliusa, czyli o sztuce, pruskiej archeologii i łodziach kultury pomorskiej, „Pomorania Antiqua”, t. 17, s. 79-114.

Lamm J.P. 1981, Frej, L. Thunmark-Nylén (red.) 1981, s. 76-77.

Lang J. 1984, The compilation of design in colonial Viking sculpture, „Universitetets Oldsaksamlings Skrifter. Ny rekke”, nr 5: Festskrift til Thorleif Sjøvold på 70-årsdagen, s. 125-137.

Lapis B. 1986, Rex utilis. Kryteria oceny władców germańskich we wczesnym średniowieczu (od połowy $V$ do poczatku VIII wieku), Poznań.

Larsson L. 2015, Expressions of cosmology at the central place of Uppåkra, southern Sweden, w: Ch. Ruhmann, V. Brieske (red.) 2015, s. 145-158.

Leciejewicz L. 1979, Normanowie, Wrocław.

- 2007, Grodzisko w Budzistowie. Badania w latach 1954-1958, w: L. Leciejewicz, M. Rębkowski (red.), Kolobrzeg. Wczesne miasto nad Battykiem, Warszawa, s. 31-110.

Le Goff J. 1994, Kultura średniowiecznej Europy, Warszawa.

- 1996, Człowiek średniowiecza, w: J. Le Goff (red.), Człowiek średniowiecza, Warszawa, s. 7-50.

Lenerz-de Wilde M. 1987, Zur Funktion der Schrift in der Frühgeschichte Mittel- und Nordeuropas, „Acta Praehistorica et Archaeologica”, t. 19, s. 85-92.

Lévi-Strauss C. 1969, Myśl nieoswojona, Warszawa.

- 1970, Antropologia strukturalna, Warszawa.

Libera Z. 1987, Semiotyka barw w polskiej kulturze ludowej $i$ w innych kulturach słowiańskich, „Etnografia Polska", t. 31, nr 1, s. 115-138.

Liebgott N.K. 1992, Knochen, Geweih, Bernstein und Walroßzahn, w: Wikinger... 1992, s. 202-203.

Lindqvist S. 1941, Gotlands Bildsteine, t. I, Stockholm.

- 1942, Gotlands Bildsteine, t. II, Stockholm. 
Lisowska E. i in. (Lisowska E., Zamelska-Monczak K., Kolenda J., Gunia P., Łydżba-Kopczyńska B.) 2017, Multidisciplinary approach to the provenance investigations of early medieval amber finds discovered in Santok and Milicz, „Fontes Archaeologici Posnanienses”, t. 53, 223-240.

Ljungkvist J. 2008, Dating two royal mounds of Old Uppsala. Evaluating the elite of the $6^{\text {th }}-7^{\text {th }}$ century in Middle Sweden, „Archäologisches Korrespondenzblatt”, t. 38, nr 2, s. 263-282.

Ljungkvist J., Frölund P., Göthberg H., Löwenborg D. 2011, Gamla Uppsala - structural development of a centre in Middle Sweden, ,Archäologisches Korrespondenzblatt”, t. 41, nr 4, s. 571-585.

Lurker M. 1989, Stownik obrazów i symboli biblijnych, Poznań.

Lyngstrøm H. 1992, Spielstein aus Bernstein (Roholte, Seeland, Dänemark), w: Wikinger... 1992, s. 247, nr 77.

Łosiński W. 1988, Chronologia napływu najstarszej monety arabskiej na terytorium Europy, „Slavia Antiqua", t. 31, s. 93-181.

- 1993 (1994), Chronologia, skala i drogi naptywu monet arabskich do krajów europejskich u schyłku IX $i$ w X w., ,Slavia Antiqua”, t. 34, s. 1-41.

- 1994 (1995), W sprawie genezy osiedli wczesnomiejskich u Stowian nadbattyckich, „Slavia Antiqua”, t. 35 , s. 101-128.

- 1999, Rolle des Frühpiastenreiches in der Geschichte der westslawisch-skandinavischen Kontakte, w: E.N. Nosov (red.) 1999, s. 129-133.

- 2008, Pomorze Zachodnie we wczesnym średniowieczu. Studia archeologiczne, Poznań.

MacGregor A. 1985, Bone, Antler, Ivory and Horn. The Technology of Skeletal Materials since the Roman Period, London.

MacGregor A., Mainman A.J., Rogers N.S.H. 1999, Craft, Industry and Everyday Life: Bone, Antler, Ivory and Horn from Anglo-Scandinavian and Medieval York, The Archaeology of York. The Small Finds, t. 17, nr 12, York.

Makowiecki D. 2003, Historia ryb i rybołówstwa w holocenie na Niżu Polskim w świetle badań archeoichtiologicznych, Poznań.

Malmer B. 1966, Nordiska mynt före år 1000, Acta Archaeologica Lundensia, series in 8, nr 4, Lund.

- 2002, Münzprägung und frühe Stadtbildung in Nordeuropa, w: K. Brandt, M. Müller-Wille, Ch. Radtke (red.) 2002, s. 117-132.

Marciniak A. 2012, Paradygmaty badawcze w archeologii, w: S. Tabaczyński i in. (red.) 2012, s. 29-83.

Markale J. 1988, Wercyngetoryks, Warszawa.

Marold E. 1998, Der gotländische Bildstein von Ardre VIII und die Hymiskviða, w: A. Wesse (red.) 1998, s. 39-48.

Matla M. 2017, Czeskie wplywy w życiu religijnym i piśmiennictwie państwa piastowskiego $w$ X-XI wieku, Uniwersytet im. Adama Mickiewicza w Poznaniu, Publikcje Instytutu Historii, nr 148, Poznań.

Merhautová A. 2000, So genannter Kamm des heiligen Adalbert, w: A. Wieczorek, H.M. Hinz (red.), Europas Mitte um 1000. Katalog zur Ausstellung, Stuttgart, s. 529.

Michajlov K.A. 2016, Elitarnyj pogrebal nyj obrjad drevnej Rusi. Kamernyje pogrebenija IX - načala XI veka $v$ kontekste severoevropejskich analogij, Sankt-Peterburg.

Michałowski R. 2016a, Chrystianizacja Saksonii, w: J. Dobosz, J. Strzelczyk, M. Matla (red.) 2016, s. 19-39.

- 2016b, Kontekst historyczny znaleziska w Bodzi, w: A. Buko (red.) 2016, s. 33-39.

Modzelewski K. 2004, Barbarzyńska Europa, Warszawa.

Moszyński K. 1967, Kultura ludowa Stowian, t. II: Kultura duchowa, cz. 1, Warszawa.

- 1968, Kultura ludowa Stowian, t. II: Kultura duchowa, cz. 2, Warszawa.

Muhl A. 1990, Ein mittelalterliches figürlich verziertes Kammfragment aus Potsdam-Babelsberg, „Acta Praehistorica et Archaeologica", t. 22, s. 121-138.

Muraseva V.V. 1992, Sitzendes Männerfigürchen (Černaja Mogila, Černigow, Ukraine), w: Wikinger... 1992, s. 308, nr 309.

- 2007, Scandinavian God 'idol'from Gnëzdovo, w: U. Fransson, M. Svedin, S. Bergerbrant, F. Androshchuk (red.) 2007, s. 97-100.

Murasheva V. zob. Muraseva V.V. 
Musin A.E. 1999, Meč i krest: novoe religioznoe soznanie Drevnej Rusi po dannym archeologii, w: E.N. Nosov (red.) 1999, s. 134-150.

- 2005, Milites Christi drevnej Rusi. Voinskaja kul tura russkogo srednevekovaja v kontekste religioznogo mentaliteta, Militaria Antiqua, t. 8, Sankt-Peterburg.

Müller-Wille M. 1980, Kungliga och furstliga gravar under merovingertiden i Central- och Västeuropa, w: A. Sandwall (red.) 1980, s. 144-157.

- 1999, Opferkulte der Germanen und Slawen, Sonderheft der Zeitschrift „Archäologie in Deutschland", Stuttgart.

- 2003 (2004), Zwischen Gudme und Reric. Frühgeschichtliche Zentralplätze Südskandinaviens und benachbarter Giebiete, „Bodendenkmalpflege in Mecklenburg-Vorpommern”, t. 51, s. 267-294.

Nielsen P.O., Randsborg K., Thrane H. (red.) 1993 (1994), The Archaeology of Gudme and Lundeborg. Papers presented at a Conference at Svendborg, October 1991, Arkæologiske Studier, t. 10, København.

Niesiołowska-Wędzka A. 1965, Wyniki badań nad tkaninami z najstarszych warstw grodu w Santoku, „Archeologia Polski”, t. 10, nr 1, s. 318-337.

Nosov E.N. (red.) 1999, Rannesrednevekovye drevnosti Severnoj Rusi i eё sosedej / Early Medieval Antiquities of the Northern Rus and its Neighbours, Sankt-Peterburg.

Nørlund P. 1937, Wikingersiedlungen in Grönland. Ihre Entstehung und ihr Schicksal, Leipzig.

Oehrl S. 2012, Bildliche Darstellungen vom Schmied Wieland und ein unerwarteter Auftritt in Walhall, w: A. Pesch, R. Blankenfeldt (red.), Goldsmith Mysteries. Archaeological, pictorial and documentary evidence from the $1^{\text {st }}$ millennium AD in northern Europe, Schriften des Archäologischen Landesmuseums Schloss Gottorf. Ergänzungsreihe, t. 8, Neumünster, s. 279-332.

Oesterreicher-Mollwo M. (red.) 1992, Herder. Leksykon symboli, Warszawa.

Page R.I. 1998, Pismo runiczne, Warszawa.

Panofsky E. 1971, Studia z historii sztuki, Warszawa.

Pedersen A. 2014, Dead Warriors in Living Memory. A Study of Weapon and Equestrian Burials in Viking-Age Denmark, AD 800-1000, Publications from the National Museum, Studies in Archaeology \& History, t. 20:1.1: Text; t. 20:1.2: Catalogue, Copenhagen.

Perkins R. 2001, Thor the Wind-Raiser and the Eyrarland Image, Viking Society for Northern Research Text Series, t. 15, London.

Pesch A. 2015, Sterbende, überlebende und auswandernde Götter, w: Ch. Ruhmann, V. Brieske (red.) 2015, s. 85-99.

Petković S. 1995, Rimski predmeti od kosti i roga sa teritorije Gornje Mezije, Beograd.

Pieczyński Z. 1962 (1963), Materialy z warstw przedsakralnych odsłoniętych w katedrze poznańskiej w latach 1951-1956, „Fontes Archaeologici Posnanienses”, t. 13, s. 246-288.

Piekarczyk S. 1979, Mitologia germańska, Warszawa.

Pleszczyński A. 2016, Postawy i działania europejskich społeczeństw pogańskich w średniowieczu wobec misji chrześcijańskich - zarys problemu, w: J. Dobosz, J. Strzelczyk, M. Matla (red.) 2016, s. 293-304.

Podgórski J.T. 1966, Obróbka rogu i kości we wczesnośredniowiecznym Santoku, Poznań (mps w bibliotece Wydziału Historycznego Uniwersytetu im. Adama Mickiewicza w Poznaniu).

Popko M. 1982, Magia i wróżbiarstwo u Hetytów, Warszawa.

Price N.S. 2002, The Viking Way. Religion and War in Late Iron Age Scandinavia, AUN 31, Uppsala.

Price N. i in. (Price N., Hedenstierna-Jonson Ch., Zachrisson T., Kjellström A., Storå J., Krzewińska M., Günther T., Sobrado V., Jakobsson M., Götherström A.) 2019, Viking warrior women? Reassessing Birka chamber grave Bj. 581, „Antiquity”, t. 93, nr 367, s. 181-198.

Radtke Ch. 2017, Auf der Suche nach den Anfängen einer Fernhändlergilde in Haithabu und Schleswig. Ein historischer Längsschnitt ca. $800-c a .1200$, w: B.V. Eriksen, A. Abegg-Wigg, R. Bleile, U. Ickerodt (red.), Interaktion ohne Grenzen. Beispiele archäologischer Forschungen am Beginn des 21. Jahrhunderts, t. 2, Schleswig, s. 693-706.

Rajewski Z.A. 1938, Gród staropolski na pótwyspie jeziora biskupińskiego w pow. żnińskim, w: J. Kostrzewski (red.), Gród prasłowiański w Biskupinie w powiecie żnińskim. Sprawozdanie z badań w latach 1936 i 1937 z uwzględnieniem wyników z lat 1934-1935, Poznań, s. 68-92. 
- 1939, Zabytki z rogu i kości w grodzie gnieźnieńskim, w: J. Kostrzewski (red.), Gniezno w zaraniu dziejów (od VIII do XIII wieku) w świetle wykopalisk, Poznań, s. 66-102.

Ramqvist P.H., Müller-Wille M. 1988, Regionale und überregionale Bedeutung des völkerwanderungszeitlichen Gräberfeldes von Högom, Medelpad, Nordschweden. Ein Vorbericht, „Germania”, t. 66, nr 1, s. 95-134.

Ratzinger J. (Benedykt XVI) b.r.w., Duch liturgii, Kraków.

Reallexikon 1917-1923 - A. Nehring (red.), Erster Band, w: O. Schrader, Reallexikon der Indogermanischen Altertumskunde. Grundzüge einer Kultur- und Völkergeschichte Alteuropas, zweite Auflage, Berlin.

Riel S. van 2017, Viking Age Combs. Local Products or Objects of Trade?, „Lund Archaeological Review", t. 23, s. 163-178.

Rijkelijkhuizen M. 2011, Dutch medieval bone and antler combs, w: J. Baron, B. Kufel-Diakowska (red.), Written in Bones. Studies on technological and social contexts of past faunal skeletal remains, Wrocław, s. 197-206.

Rjabinin E.A. 1985, Novye otkrytija v Staroj Ladoge (itogi raskopok na Zemljanom gorodišče 1973-1975 gg.), w: V.V. Sedov (red.) 1985, Leningrad, s. 27-75.

Rjabinin E.A., Černych N.B 1988, Stratigrafija, zastrojka i chronologija nižnego sloja Staroladožskogo Zemljanogo gorodišča v svete novych issledovanij, ,Sovetskaja Archeologija”, nr 1, s. 72-100.

Roes A. 1963, Bone and Antler Objects from the Frisian Terp-Mounds, Haarlem.

- 1965, Vondsten van Dorestad, Archaeologica Traiectina edita ab Academiae Rheno-Traiectinae Instituto Archaeologico, t. 7, Groningen.

Roesdahl E. 1991, The Vikings, London.

Romaniak M. 2016, Zapożyczenia w polskim słownictwie fryzjerskim, „Słowo. Studia językoznawcze”, t. 7, s. 208-219.

Ros J. 1992, Einzeiliger Dreilagenkamm (Sigtuna, Uppland, Schweden), w: Wikinger... 1992, s. 380, nr 578.

Rosik S. 2007, Gdy radosne widowisko przeradza się w horror. Łowienie emocji w przekazie hagiograficznym (przykład z żywotu św. Ottona: Ebo III, 10-11), w: S. Rosik, P. Wiszewski (red.), Cor hominis. Wielkie namiętności $w$ dziejach, źródłach i studiach nad przeszłościa, Acta Universitatis Wratislaviensis, nr 3049, seria Historia, nr 176, Wrocław, s. 369-375.

Roth H. (red.) 1986, Zum Problem der Deutung frühmittelalterlicher Bildinhalte, Sigmaringen.

Ruhmann Ch., Brieske V. (red.) 2015, Dying Gods - Religious beliefs in northern and eastern Europe in the time of Christianisation, Neue Studien zur Sachsenforschung, t. 5, Hannover.

Sandwall A. (red.) 1980, Vendeltid, Stockholm.

Schlette F. 1987, Celtowie, Łódź.

Schmid P. 1969, Zum heidnischen und frühchristlichen Bestattungsbrauch auf dem frühmittelalterlichen Gräberfeld von Dunum, Ostfriesland, „Frühmittelalterliche Studien”, t. 3, s. 257-276.

Schmidt H. 1991, Reconstruction of the Lejre Hall, „Journal of Danish Archaeology”, t. 10, s. 186-190.

Schnitzler Th. 1960, Kamm, w: Lexikon für Theologie und Kirche, t. 5, wyd. 2, Freiburg, kolumna 1270.

Sedov V.V. (red.) 1985, Srednevekovaja Ladoga. Novye archeologičeskie otkrytija i issledovanija, Leningrad.

Sergeeva M.S. 2010 (2011), Kostorizna sprava u starodavn'omu Kievi, Kiïv.

Shetelig H. 1933, Vikingeminner i Vest-Europa, Oslo.

Simek R. 2003, Religion und Mythologie der Germanen, Darmstadt.

Sindbæk S.M. 2007, Networks and nodal points: the emergence of towns in early Viking Age Scandinavia, „Antiquity”, t. 81, nr 311, s. 119-132.

Skre D. (red.) 2008, Means of Exchange. Dealing with Silver in the Viking Age, Kaupang Excavation Project Publication Series, t. 2, Norske Oldfunn XXIII, Aarhus.

Sláma J. 1977, Mittelböhmen im frühen Mittelalter, t. 1: Katalog der Grabfunde, Acta Instituti Praehistorici Universitatis Carolinae Pragensis, Praehistorica, t. 5, Praha.

Słupecki L.P. 2003, Mitologia skandynawska w epoce Wikingów, Kraków.

- 2011, Wojownicy $i$ wilkołaki, wyd. 3, Warszawa. 
Smirnova L. 2005, Comb-Making in Medieval Novgorod (950-1450): An industry in transition, BAR International Series 1369, Oxford.

Smith J.M.H. 2008, Europa po Rzymie. Historia kulturowa lat 500-1000. Nowe ujęcie, Kraków.

Staecker J. 1999, Thor's Hammer - Symbol of Christianization and Political Delusion, „Lund Archaeological Review", t. 5, s. 89-104.

Staszczak Z. (red.) 1987, Stownik etnologiczny. Terminy ogólne, Warszawa.

Steinsland G. 1992, Altnordisches Heidentum, w: Wikinger... 1992, s. 144-151.

Strzelczyk J. 1992, Mieszko Pierwszy, Poznań.

- 1998, Mity, podania i wierzenia dawnych Stowian, Poznań.

Suchocki J. 1987, Co stońce robi noca? Przyczynek do rozważań nad wizja świata w battyjskich kulturach ludowych. Na materiale dain totewskich, „Etnografia Polska”, t. 31, nr 1, s. 139-159.

Sundqvist O. 2011, Gudme on Funen: a central sanctuary with cosmic symbolism?, w: O. Grimm, A. Pesch (red.) 2011, s. 63-76.

Tabaczyńska E. 1959, Obróbka metali nieżelaznych, rogu i kości oraz bursztynu we wczesnośredniowiecznym Kołobrzegu, w: W. Łosiński, E. Tabaczyńska, Z badań nad rzemiostem we wczesnośredniowiecznym Kołobrzegu, Poznań, s. 57-119.

Tabaczyński S. 2012, Kultura i kultury, w: S. Tabaczyński i in. (red.) 2012, s. 571-604.

Tabaczyński S. i in. (red.) (Tabaczyński S., Marciniak A., Cyngot D., Zalewska A. [red.]) 2012, Przeszłość społeczna. Próba konceptualizacji, Poznań.

Tempel W.D. 1970, Die Kämme aus Haithabu (Ausgrabung 1963-1964), w: Berichte über die Ausgrabungen in Haithabu, t. 4: Das archäologische Fundmaterial I der Ausgrabung Haithabu 1963-1964, Neumünster, s. 34-45.

- 1979, Die Kämme aus der frühgeschichtlichen Wurt Elisenhof, w: H. Steuer, Die Keramik aus der frühgeschichtlichen Wurt Elisenhof / W.D. Tempel, Die Kämme aus der frühgeschichtlichen Wurt Elisenhof, Studien zur Küstenarchäologie Schleswig-Holsteins, seria A: Elisenhof, t. 3, Frankfurt a.M., s. 149-171.

Tesch S. 1992, Zwei Kämme (Sigtuna, Uppland, Schweden), w: Wikinger... 1992, s. 386, nr 598.

- 2015, A Lost World? Religious identity and burial practices during the introduction of Christianity in the Mälaren region, Sweden, w: Ch. Ruhmann, V. Brieske (red.) 2015, s. 191-210.

Thieme W., Laux F. i in. 1978, Katalog, w: C. Ahrens (red.) 1978, s. 543-698.

Thunmark-Nylén L. (red.) 1981, Vikingatidens ABC, Stockholm.

Toporow W.N. 2003, Przestrzeń i rzecz, Kraków.

Trotzig G. 1984, Gefässe aus Kupfer und seinen Legierungen, w: G. Arwidsson (red.) 1984, s. 219-230.

Ulbricht I. 1978, Die Geweihverarbeitung in Haithabu, Die Ausgrabungen in Haithabu, t. 7, Neumünster.

Van de Noort R. 1993, The context of Early Medieval barrows in western Europe, „Antiquity”, t. 67, nr 254, s. 66-73.

Vierck H. 1972 (1973), Redwalds Asche. Zum Grabbrauch in Sutton Hoo, Suffolk, „Offa”, t. 29, s. 20-49.

- 1978, Religion, Rang und Herrschaft im Spiegel der Tracht, w: C. Ahrens (red.) 1978, s. 271-283.

Vilhjálmsson V.Ö. 1992, Spielsteine und Würfel (Baldursheimur, Nordland, Island), w: Wikinger... 1992, s. $246, \mathrm{nr} 71$.

Wahlöö C. 1992, Spielstein (Lund, Schweden), w: Wikinger... 1992, s. 387, nr 602.

Wamers E. 1997, Hammer und Kreuz. Typologische Aspekte einer nordeuropäischen Amulettsitte aus der Zeit des Glaubenswechsels, w: M. Müller-Wille (red.), Rom und Byzanz im Norden. Mission und Glaubenswechsel im Ostseeraum während des 8.-14. Jahrhunderts, t. 1, Mainz, s. 83-107.

Wasilewski J.S. 1978, Symbolika ruchu obrotowego i rytualnej inwersji, „Etnografia Polska”, t. 22, nr 1, s. 81-108.

- 1987, Tabu, zakaz magiczny, nieczystość, cz. 1: Zrozumieć tabu, „Etnografia Polska”, t. 31, nr 1, s. 19-41.

Weber B. 1993, Norwegian reindeer antler export to Orkney. An analysis of combs from Pictish / early Norse sites, „Universitetets Oldsaksamling Årbok” 1991/1992, s. 161-174.

Wesse A. (red.) 1998, Studien zur Archäologie des Ostseeraumes. Von der Eisenzeit zum Mittelalter. Festschrift für Michael Müller-Wille, Neumünster.

Wiessner P. 1983, Style and Social Information in Kalahari San Projectile Points, „American Antiquity”, t. 48 , nr 2, s. $253-276$. 
Wikinger... 1992: Wikinger - Waräger - Normannen. Die Skandinavier und Europa 800-1200, Berlin. Wilde K.A. 1953, Die Bedeutung der Grabung Wollin 1934. Methodische Grundlagen für die Erforschung der Wikinger- und Slawen-Siedlung Wollin, Hamburg.

Wilke G. 1915, Weitere Beiträge zur Heilkunde in der Indoeuropäischen Vorzeit, „Mannus”, t. 7, s. 1-31. Wilson D.M., Klindt-Jensen O. 1980, Viking Art, wyd. 2, London.

Yotov V. 2018, Data about Northmen's presence in the Lower Danube area, w: D. Aparaschivei, G. Bilavschi (red.), Studia Romana et Mediævalia Europænsia.

Miscellanea in honorem annos LXXXV peragentis Professoris emeriti Dan Gh. Teodor oblata, Bucureşti, s. $467-484$.

Zamelska-Monczak K. 2014 (2015), Wczesnośredniowieczne grzebienie z Santoka, „Materiały Zachodniopomorskie", nowa seria, t. 11, nr 1, s. 45-92.

Zbierski A. 1985, Kultura mieszkańców, w: E. Cieślak (red.), Historia Gdańska, t. 1: do roku 1454, Gdańsk, s. 234-259.

Żak J. 1963, „Importy” skandynawskie na ziemiach zachodniostowiańskich od IX do XI wieku (część katalogowa), Poznań.

- 1967, „Importy” skandynawskie na ziemiach zachodniostowiańskich od IX do XI wieku (część analityczna), Poznań. 